\title{
UNA BIBLIOGRAFÍA (SELECTA) PARA LA RECONSTRUCCIÓN DE LA VIDA ESCÉNICA ESPAÑOLA EN LA SEGUNDA MITAD DEL SIGLO XIX ${ }^{1}$
}

\author{
José Romera Castillo
}

Universidad Nacional de Educación a Distancia

\section{Pórtico}

Como he escrito en otro lugar ${ }^{2}$, en la década de los ochenta pensaba que era preciso crear en España un Centro de Estudios que sirviese para profundizar más en la investigación de la semiótica. Así nació, bajo mi dirección, en 1991 - aunque pergeñado con anterioriedadel Instituto de Semiótica Literaria y Teatral, inserto en el Departamento de Literatura Española y Teoría de la Literatura, de la Facultad de

1 Esta investigación ha sido subvencionada en dos ocasiones por la Dirección General de Investigación Científica y Técnica (DGICYT) y la Dirección General de Enseñanza Superior del Ministerio de Educación y Cultura: Proyectos PS90-0104 (1990-1993) y PB96-0002 (1997-2000).

2 Cf. José Romera Castillo, «El Instituto de Semiótica Literaria, Teatral y Nuevas Tecnologías en el ámbito de mi trayectoria semiótica». Signa. Revista de la Asociación Española de Semiótica 8 (1999), 151-177. 
Filología de la Universidad Nacional de Educación a Distancia (UNED) ${ }^{3}$. El ISLTYNT —en el siglo de las siglas - ha pretendido conseguir varios objetivos, de los que ya ha conseguido granados frutos: organizar anualmente un Seminario Internacional ${ }^{4}$, publicar Signa. Revista de la Asociación Española de Semiótica ${ }^{5}$, realizar tesis de doctorado, cursos y conferencias, etc.

Una de las labores más importantes del ISLTYNT ha sido la de realizar en su seno una serie de investigaciones con el fin de reconstruir la vida escénica en España, fundamentalmente, en la segunda mitad del siglo XIX y siglo XX. Como es bien sabido, conocemos muy bien la historia literaria de los autores y de los textos dramáticos, pero sabemos mucho menos de la historia de las obras que fueron contempladas y degustadas por nuestros antecesores. Para subsanar esta laguna -a veces océano inmenso - hemos llevado a cabo - y seguimos haciendo- una serie de investigaciones que, unidas a las realizadas por otros grupos de investigación, van aportando bastante luz a la historia del teatro representado en España.

Nuestras aportaciones se caracterizan por estar insertas en un amplio grupo de trabajo, diseñado con rigor y minuciosidad, sobre la semiosis de todos los componentes que articulan la representación en diferentes lugares de España y la presencia del teatro español en el extranjero (México e Italia). Las características de mi alumnado de la UNED así lo determinaban. El interés del trabajo de investigación ha sido ya reconocido al ser subvencionado y reconocido por los estudiosos del tema.

3 Posteriormente - por el radio de acción de sus investigaciones - recibiría, desde 1996, el nombre que actualmente posee: Instituto de Semiótica Literaria, Teatral y Nuevas Tecnologías.

4 Cf. José Romera et alii (eds.), Ch. S. Peirce y la literatura, Signa. Revista de la Asociación Española de Semiótica 1 (1992), 242 págs.; José Romera et alii (eds.), Escritura autobiográfica (Madrid: Visor Libros, 1993, 505 págs.); José Romera et alii (eds.), Semiótica(s). Homenaje a Greimas (Madrid: Visor Libros, 1994, 326 págs.); José Romera et alii (eds.), Bajtín y la literatura (Madrid: Visor Libros, 1995, 459 págs.); José Romera et alii (eds.), La novela histórica a finales del siglo XX (Madrid: Visor Libros, 1996, 439 págs.); José Romera et alii (eds.), Literatura y multimedia (Madrid: Visor Libros, 1997, 386 págs); J. Romera Castillo y F. Gutiérrez Carbajo (eds.), Biografías literarias (1975-1997) (Madrid: Visor Libros, 1998, 647 págs.); J. Romera y F. Gutiérrez (eds.), Teatro histórico (1975-1998): textos y representaciones (Madrid: Visor Libros, 1999, 755 págs.); J. Romera y F. Gutiérrez (eds.), Poesía histórica y (auto)biográfica (1975-1999) (Madrid: Visor Libros, 2000) y J. Romera y F. Gutiérrez (eds.), El cuento en la década de los noventa (Madrid: Visor Libros, 2001, e.p.).

Se han publicado, desde 1992 y hasta el momento, 9 números. 
Como he escrito en otro lugar, nuestro trabajo consiste, muy sintéticamente, en lo siguiente. Una vez elegido el punto geográfico en el que se investigará la vida escénica en toda su amplitud en un periodo determinado de años - en función de la documentación que sea accesible_-, se traza, en primer lugar, un panorama histórico, literario y teatral de la época tanto general de España como de la ciudad, objeto de estudio. A continuación se compila un estado de la cuestión sobre la bibliografía referida a la actividad escénica en el lugar seleccionado, estableciendo las fuentes documentales (archivos, hemerotecas, etc.) sobre las que se basará la investigación. Después se estudian los espacios teatrales de la localidad (teatros propiamente dichos y otros ámbitos como Casinos, Ateneos, casas particulares, etc.).

Asentadas las bases de la investigación, entramos de lleno en el núcleo fundamental de la misma, constituido por el establecimiento de la cartelera teatral (obras representadas y obras anunciadas que no llegaron a ponerse en escena por diversos motivos), desde un punto de vista cronológico, en la que se constatan para cada año, mes, día y hora, por funciones, en las sesiones de tarde y noche, los títulos de las piezas y los nombres de los autores que se representaron, los lugares escénicos, así como las compañías y actores, constatando siempre la referencia bibliográfica de donde se toman los datos.

Una vez establecida la cartelera, nos centramos en la relación de las obras (con un índice alfabético y una relación númerica de las veces que las obras se pusieron en escena) y su clasificación por géneros (comedias, tragedias, dramas, melodramas, etc.) tanto del teatro declamado (obras originales o traducciones-adaptaciones de piezas de teatro foráneo - la mayoría de las veces francesas-), como del teatro lírico musical (ópera, zarzuela) y género chico, intermedios (bailes, canciones, poesías, etc.) y espectáculos parateatrales (acrobacias, malabarismos, magias, etc.). Después se estudian los autores (dramaturgos, adaptadores, libretistas y compositores), con sus obras respectivas.

A continuación, nos centramos en todo lo relacionado con la representación teatral en su conjunto. En primer lugar, atendemos a las compañías (tanto profesionales como de aficionados -que tanto proliferaron-), estableciendo la relación de sus componentes y el repertorio de obras representadas. Como consecuencia de este estudio, tenemos ya unos itinerarios de las diversas compañías que recorrieron todo el territorio nacional. Después, pasamos al análisis de los distintos lenguajes escénicos (escenografía, música, vestuario, luminotecnia, etc.). 
Para ello nos servimos del marco teórico de la semiótica teatral que tanto ha aportado al respecto. Los resultados de este apartado son de extraordinario valor para la historia de la representación escénica, sobre la que poseemos escasos datos, ya que desafortunadamente no existían los medios tecnológicos de hoy (grabaciones de televisión, vídeo, etc.), y que gracias a estas aportaciones vamos teniendo noticias más pormenorizadas.

Después, analizamos la recepción crítica de los espectáculos teatrales, examinando la relación de críticos (siempre que es posible) así como la crítica de los autores, de los textos dramáticos, de las compañías, de las puestas en escena, etc.

La sociología del hecho teatral no podía estar ausente. Desde las reglamentaciones oficiales sobre el teatro (tanto nacionales como provinciales), problemas de censura, representaciones a beneficio (de Instituciones, actores, etc.), aficiones poéticas y musicales en los intermedios, regalos, homenajes y agradecimientos, etc. Después, estudiamos, hecho importantísimo, la temporadas teatrales (épocas y meses del año, días de la semana, horario de las funciones, etc.); analizamos los precios (por abonos y entradas sueltas); para terminar recogiendo las costumbres del público asistente a las representaciones que eran muy pintorescas en ocasiones (sombreros de las señoras que no dejaban ver bien el escenario, comportamientos soeces, etc.).

Teniendo como colofón unas conclusiones generales, con un análisis de la vida escénica en el lugar escogido, que, por sí mismas, constituyen una pequeña monografía lista para la imprenta; además de las referencias bibliográficas y una serie de apéndices, sobre todo gráficos (planos de teatros, fotografías, documentos manuscritos, programas de mano, anuncios en periódicos, etc.), que hasta el momento eran, en general, desconocidos.

$\mathrm{Y}$ es todo. Como se puede colegir, un amplio abanico que trata de reconstruir muy pormenorizadamente no sólo las informaciones que las fuentes documentales aportan, día tras día, sino que pretenden realizar, sobre todo, un análisis valorativo y comparativo con lo ya conocido de las actividades escénicas en su integridad del punto geografico elegido, puesto en relación con la vida escénica española.

En estos dieciséis años de vida del proyecto, desde que en 1984 empezamos a trabajar, hemos producido enjundiosos frutos (tesis de doctorado y Memorias de Investigación), como a continuación enumero. 
Sobre la segunda mitad del siglo XIX se ha investigado la vida escénica, a través de tesis de doctorado, en siete ciudades ${ }^{6}$. He aquí la relación: Emilia Cortés Ibáñez, El teatro en Albacete en la segunda mitad del siglo XIX (1991) - publicada en microforma por la UNED en 1991 y posteriormente como El teatro en Albacete en la segunda mitad del siglo XIX. Documentos, cartelera y estudio (Albacete: Diputación / Instituto de Estudios Albacetenses «Don Juan Manuel», 1999, 395 págs., con prólogo de José Romera Castillo)_-; José Antonio Bernaldo de Quirós, El teatro y actividades afines en Ávila (siglos XVII, XVIII y XIX) (1993) —publicada en microforma por la UNED en 1994 y posteriomente como Teatro y actividades afines en la ciudad de Ávila (Siglos XVII, XVIII y XIX) (Ávila: Diputación Provincial / Institución Gran Duque de Alba, 1998, 342 págs., con prólogo de José Romera Castillo)-; Ángel Suárez Muñoz, La vida escénica en Badajoz 1860-1886 (1994) -publicada en microforma por la UNED en 1995 y posteriormente como El teatro en Badajoz: 1860-1886. Cartelera y estudio (Madrid: Támesis, 1997, 343 págs., Colección «Fuentes para la historia del teatro en España», . $^{\circ}$ XXVIII)_; María del Mar López Cabrera, El teatro en Las Palmas de Gran Canaria (1853-1900) (1995) — publicada en microforma por la UNED en 1995-; Agustina Torres Lara, La escena toledana en la segunda mitad del siglo XIX (1996); Tomás Ruibal Outes, La vida escénica en Pontevedra en la segunda mitad del siglo XIX (1997) — publicada en microforma por la UNED en 1998 - y Estefanía Fernández García, León y su actividad escénica en la segunda mitad del siglo XIX (1997) — publicada en microforma por la UNED en 1998-.

Además se han realizado siete Memorias de Investigación -inéditas- sobre algunos años concretos, que se convertirán -algunas de ellas- en tesis de doctorado: El teatro en Cádiz (1867-1870), de Amalia Vilches Dueñas (1984); El teatro en Calahorra (1840-1910), de María Á. Martínez Somalo (1988); El teatro en Córdoba (1854-1858), de María Teresa Gómez Borrego (1988); El teatro en Barcelona en la segunda mitad del siglo XIX (1850-1854), de Ana María Grau Gutiérrez (1992); El teatro en Igualada en la segunda mitad del siglo XIX (1863-1880), de María Rosa Vila Farré (1992); El teatro en Bilbao

6 En el Departamento de Historia del Arte, de la UNED, se defendió la tesis de doctorado de Juana María Balsalobre García (1997), Imagen académica del teatro español decimonónico. El teatro y su censura en la Real Academia de Bellas Artes de San Fernando (1800-1870), bajo la dirección del Dr. José Enrique García Melero. Publicada en microforma por la UNED en 1998. 
(1890-1892), de Begoña Alonso Bocos (1996) y La vida escénica en el teatro Jofre de Ferrol: 1892-1896, de M. ${ }^{a}$ Eva Ocampo Vigo (1997).

Sobre el siglo XX, se han defendido cuatro tesis de doctorado. He aquí su relación: Francisco Reus-Boyd-Swan, El teatro en Alicante (1900-1910) (1991) — publicada, primeramente, en microforma por la UNED en 1992 y posteriormente como El teatro en Alicante: 1901 1910. Cartelera y estudio (Madrid / Londres: Támesis / Generalitat Valenciana, 1994, 438 págs., Colección «Fuentes para la historia del teatro en España», $\mathrm{n}^{\circ}$ XXIII)-; Francisco Linares Valcárcel, La vida escénica en Albacete (1901-1923) (1997) — publicada en microforma por la UNED en 1998 y posteriormente como Representaciones teatrales en Albacete, 1901-1923. Cartelera, compañías y valoración (Albacete: Instituto de Estudios Albacetenses «D. Juan Manuel», 1999; con prólogo de José Romera Castillo)- y Emilia Ochando Madrigal, El teatro en Albacete (1924-1936) (1998) - publicada en microforma por la UNED en 1998 y posteriormente como El teatro en Albacete durante la Edad de Plata (1924-1936) (Albacete: Instituto de Estudios Albacetenses «Don Juan Manuel», 2000; con prólogo de José Romera Castillo- y Alfredo Cerda Muños, La actividad escénica en Guadalajara (México): 1920-1990 — defendida en la UNED, 1999-.

Asimismo, Paloma González-Blanch Roca, ha realizado su Memoria de Investigación sobre La vida escénica en Segovia (1918-1923) (1998). Se han investigado otros puntos de la geografía española ${ }^{7}$ y hay otros trabajos en curso de realización.

Hay que decir que las tesis de doctorado han sido publicadas -0 aguardan su publicación - en microforma por la UNED. Algunas de

7 Añadiré que se han realizado Memorias de Investigación, integradas en nuestro Instituto, sobre temporadas teatrales en otros puntos de la geografía española, bajo la tutela de mis colaboradores:

a) Dr. ${ }^{\text {a M. }}{ }^{\text {a }}$ Pilar Espín Templado: El teatro en La Rioja en la segunda mitad del siglo XIX, de Inmaculada Benito Argáiz (1997) — defendida en la Universidad de La Rioja en 1997 (codirigida por Miguel Ángel Muro)—; El teatro en Badajoz en la primera mitad del siglo XX (1900-1902), de Pablo Fernández García (1995); La vida escénica en Pontevedra en la primera mitad del siglo XX (19011903), de Paulino Aparicio Moreno (1996) - que pronto, con ampliación de los años de estudio, se convertirá en tesis de doctorado- y El teatro en la ciudad de Santander (1898-1900), de Fernando Sánchez Rebanal (1999).

b) Dr. ${ }^{\mathrm{a}}$ M. $^{\mathrm{a}}$ Clementa Millán: El teatro en Santander (1910-1912), de José Ismael Álvarez Garzón (1999).

c) Dr. Francisco Gutiérrez Carbajo: Representaciones teatrales y compañías de teatro profesional gallegas en 1993, de Fernando Dacosta Pérez (1998).

Además de otras en preparación. 
ellas, además, han sido editadas por la prestigiosa Colección «Fuentes para la historia del teatro en España», de la editorial londinense / madrileña Tamesis Books (Badajoz y Alicante), por Instituciones locales (Albacete, Ávila) y algunas otras serán publicadas pronto por entidades provinciales (León, etc.)

En conjunto, por lo que respecta al siglo XIX, se han investigado catorce puntos geográficos de España: Albacete, Ávila -que cubre los siglos XVII, XVIII y XIX -, Badajoz, Las Palmas de Gran Canaria, Toledo, Pontevedra y León - sobre la vida escénica en la segunda mitad del siglo XIX -; además de algunos años de las carteleras teatrales de Cádiz, Calahorra, Córdoba, Barcelona, Igualada, Bilbao y Ferrol.

Por lo que concierne al siglo XX, se han realizado, bajo mi dirección, las carteleras de Alicante (1900-1910), Albacete (1901-1936) y Segovia (1918-1923); así como algunas Memorias sobre algunas temporadas teatrales, integradas en el equipo de investigación, realizadas bajo la dirección de mis colaboradores M. ${ }^{a}$ Pilar Espín Templado, Francisco Gutiérrez Carbajo y M. ${ }^{a}$ Clementa Millán.

Pero el ámbito de actuación de nuestro equipo no se detiene sólo en España, sino que el radio de acción se ha ampliado a otros países. Tal es el caso de la tesis de doctorado sobre La actividad escénica en Guadalajara (México) 1920-1990, de Alfredo Cerda Muños (1999) - ya citada-; además de otra, en proceso de culminación, sobre La vida escénica del teatro español del siglo XX en Italia (1960-1998), de Coral García Rodríguez.

En síntesis, las pesquisas en cerca de una veintena de puntos geográficos de España -entre los que resaltan los amplios panoramas de Albacete y Ávila-, más las dos del extranjero (México e Italia), constituyen un corpus muy significativo que arroja una intensísima luz no sólo de la vida escénica de estos lugares, sino que, gracias a nuestra iniciativa y sobre todo al esfuerzo de nuestros investigadores - a los que desde aquí quiero reconocer y agradecer su denodado esfuerzo-, al estar ya cruzando y comparando los datos ${ }^{8}$, la historia de nuestro

8 Cf. José Romera Castillo, «El personaje en escena (Un método de estudio)», en Jesús G. Maestro (ed.), Theatralia II. El personaje teatral (Vigo: Universidade, 1998, 77-108), en el que se expone la rentabilidad que se le puede extraer a estas investigaciones, al cruzar datos de las diferentes tesis de doctorado ya realizadas, tanto para el estudio del personaje del texto literario teatral (autor teatral y personajes de sus obras dramáticas) como del personaje en el escenario (información sobre los actores que representan a los personajes, juicios sobre su interpretación y recepción del personaje por el público). 
teatro representado ya no es una anhelada utopía, sino una rigurosa y bien fundada realidad.

Para poner en funcionamiento el grupo de investigación y para seguir trabajando he tenido que recopilar una base de datos bibliográficos, divididos sectorialmente (Teatro de la época, Autores, Obras, Géneros, Teatro regional, diversos aspectos de la representación teatral, Historia, Prensa, etc.) que hasta el momento estaban dispersos y que son de tanta utilidad - puedo dar fe de ello- para los que empiezan a investigar en dicha parcela. Por ello, con el fin de ayudar tanto a los investigadores del ISLTYNT como a quienes se interesen por el tema, ofrecemos una relación bibliográfica sobre diversos aspectos que articulan el estudio de las prácticas escénicas en la segunda mitad del siglo XIX, fundamentalmente, en España. Ni que decir tiene que a esta nómina, en modo alguno exhaustiva - sobre todo en autores y obras-, se le podrán añadir otras referencias bibliográficas. Eso es lo que pretendo: que este listado se complete con lo que aquí falte o sea necesario rectificar. Entre todos avanzaremos más certeramente. Además, algunas fichas bibliográficas consignadas en un apartado podrían añadirse a otro(s).

\section{SOBRE TEATRO DEL SIGLO XIX}

\section{II.1. Estudios}

Alaminos Sánchez, M. y Sánchez de la Plaza, H. (1860). El teatro español bajo su verdadero punto de vista. Folleto escrito exponiendo su situación actual, abusos en la literatura dramática, deseos de corregirlos. Madrid: Imprenta de D. Francisco del Castillo.

ABRIL, M. (s.a). El arte de las sombras. Madrid: Aguilar.

AdAms, N. B. (1926a). «Notes on Spanish Plays at the Beginning of the Romantic Period». Romanic Review XVII, 128-142.

- (1930). «The Grotesque in Some Important Spanish Romantic Plays». Todd Memorial Volumes, Philological Studies I, 37-46.

- (1945). «Notes on Dramatic Criticism in Madrid: 1828-1933». En Studies in Language and Literature, 231-238. Chapel Hill: University of North Carolina Press. [Studies in Philology XLII, 1945, 609-616.] 
Alas, L. (1887). «Temporada teatral». En Nueva campaña (18851886) (Madrid), 273-278.

Alcalá Galiano, A. (1886). Memorias. Madrid: Rubiños.

- (1955). Recuerdos de un anciano. En Obras escogidas, I. Madrid: Atlas (BAE). Edición de Jorge Campos.

- (1969). Literatura española del siglo XIX. De Moratín a Rivas. Madrid: Alianza (Traducción, introducción y notas de Vicente Lloréns). [La edición original en inglés apareció en 1834.]

Alcina Franch, J. (1979). Teatro romántico. Barcelona: Bruguera.

Alonso CoRTÉs, N. (1940-41). «Sobre el drama romántico». Castilla I, 103-114.

- (1968). «El teatro español en el siglo XIX». En Historia de las Literatura Hispánicas, G. Díaz-Plaja (ed.), IV, 261-337. Barcelona: Vergara.

AlsinA, J. (1919). Museo Dramático. Madrid: Renacimiento.

ÁlVAREZ BARrIENTOS, J. et alii (1997). «El teatro (I)». En Historia de la literatura española. Siglo XIX (I), V. García de la Concha (ed.) y G. Carnero (coord.), t. 8, 235-289. Madrid: Espasa Calpe.

ÁlVAREZ BARRIENTOS, J. et alii (1998). «El teatro durante la Restauración y el fin de siglo». En Historia de la literatura española. Siglo $X I X(I I)$, V. García de la Concha (ed.) y L. Romero Tobar (coord), t. 9, 107-200. Madrid: Espasa Calpe.

Álvarez EsPINo, R. (1876). Ensayo histórico-crítico del teatro espanol, desde su origenes hasta nuestros días. Madrid: Tip. La Comercial. [Historia y antología de textos.]

AMORós, A. (1999). «Teatro popular». En Historia de los espectáculos en España, Andrés Amorós y José M. ${ }^{a}$ Díez Borque (eds.), 135145. Madrid: Castalia.

ARDERÍUS, F. (1877). Hasta los gatos quieren zapatos. Apuntes sobre el teatro español. Madrid: Velasco y Romero.

- (1876). Ateneo de Madrid. Sección de Literatura y Bellas Artes. Discusión sobre el tema: «¿Se halla en decadencia el teatro español? Si se halla ¿por qué medios pudiera procurarse su regeneración?». Revista Europea (Madrid), VII, 237-239, 274277 y 546-547. [Sirvió de punto de partida una Memoria pre- 
sentada por J. Alcalá Galiano. Intervinieron Fernández Jimémez, Vidart y Revilla, pronunció un discurso Valera y resumió los debates con otros F. de P. Canalejas.]

Aubrun, Ch.-V. (1965). Histoire du théâtre espagnol. París: PUF.

Aymes, J. R. y Fernández Sebastí́n, J. (1997). La imagen de Francia en España (1808-1850). Bilbao: Universidad del País Vasco.

AZNAR SOLER, M. (1990). «El teatre romàntic espanyol» $\mathrm{y}$ «El teatre espanyol (1890-1960)». En Història del teatre, Vito Pandolfi (ed. de J. M. Benet i Jornet y J. M. Carandell), II y III, 223-238, 377398, respectivamente. Barcelona: Institut del Teatre.

BAASNER, F. (1995). Literaturgeschichsschreibung in Spanien von den Anfängen bis 1868. Frankfurt am Main: Klosterman.

BARINAGA, A. (1964). Movimientos literarios españoles de los siglos $X I X$ y XX. Madrid: Alhambra.

Blanco Garcí, F. (1891-1894). La literatura española en el siglo XIX. Madrid: Sáenz de Jubera Hermanos, 3 vols. [2. ${ }^{a}$ ed., 1899$1904 ; 3 .^{a}$ ed., 1909-1912.]

Blasco, E. (1897). «Las costumbres en el teatro: su influencia recíproca. Bretón de los Herreros, N. Serra, V. de la Vega, Ayala». La España del siglo XIX III, 141-143.

BOTREL, J.-F. (1977). «El teatro en provincias bajo la Restauración. Un medio popular de comunicación». Bulletin Hispanique LXXIX (34), 381-393.

- (1985). Pour une histoire littéraire de l'Espagne (1868-1914). Université de Lille III, Atelier National de Reproduction des Thèses, 2 vols.

- (1988). La diffusion du livre en Espagne (1868-1914). Les libraires. Madrid: Casa de Velázquez.

BRETón DE LOS HERREROS. M. (1828). Contra el furor filarmónico o más bien contra los que desprecian el teatro español. Madrid: Burgos.

- (1846). «Literatura dramática. Reseña de un debate sostenido en el Liceo de Madrid». Revista Literaria de El Español I, 14-16.

- (1965). Manuel Bretón de los Herreros. Obra dispersa, I. El Correo Literario y Mercantil. Logroño: Instituto de Estudios Riojanos (Edición y estudio de J. M. Díez Taboada y J. M. Rozas). [Contiene textos sobre teatro.] 
BRETT, L. E., ed. (1935). Nineteenth Century Spanish Plays. Nueva York: Appleton Century Crofts.

Bueno, M. (1909). Teatro español contemporáneo. Madrid: V. Prieto y Compañía.

CAldera, E. (1962). Primi manifesti del romanticismo spagnolo. Pisa: Istituto di Letteratura Spagnola e Ispano-Americana.

- (1974). Il dramma romantico in Spagna. Pisa: Università.

- (1978). La commedia romantica in Spagna. Pisa: Giardini.

- (1982). Romanticismo I. Atti del II Congresso sul Romanticismo spagnolo e ispanoamericano (Asppetti e problemi del teatro romantico). Génova: Universidad.

- (1999). «Siglo XIX». En Historia de los espectáculos en Espa$\tilde{n} a$, Andrés Amorós y José M. ${ }^{a}$ Díez Borque (eds.), 87-103. Madrid: Castalia.

CALDERA, E., ed. (1992). Teatro politico spagnolo del primo Ottocento. Roma: Bulzoni.

Caldera, E. y Calderone, A. (1988). «El teatro en el siglo XIX (I) (1808-1844)». En Historia del teatro en España, II, J. M. ${ }^{a}$ Díez Borque (ed.), 377-624. Madrid: Taurus.

CALDERA, E. y Froldi, R., eds. (1991, 1993). EntreSiglos 1 y 2. Roma: Bulzoni.

CALvo ASENSIO, C. (1875). El teatro hispano-lusitano en el siglo XIX. Apuntes críticos. Madrid: Imprenta Rojas.

CAMBronero, C. (1914). Crónicas del tiempo de Isabel II. Madrid: La España Moderna.

CAMPos, J. (1969). Teatro y sociedad en España (1700-1820). Madrid: Moneda y Crédito.

Canalejas, F. de P. (1876). La poesía dramática en España. Madrid: Imprenta de Víctor Saiz.

Cánovas del Castillo, A. (1885). El teatro español. Madrid: Editorial Iberoamericana.

Carballo Picazo, A. (1955). «Los estudios de preceptiva y métrica españoles en los siglos XIX y XX». Revista de Literatura VIII, 23-56. 
CARNER, S. J. (1890). Tratado de arte escénico. Barcelona: Establecimiento Tipográfico de La Hormiga de Oro.

CARNERo, G. (1978). Los orígenes del Romanticismo reaccionario español. El matrimonio Böhl de Faber. Valencia: Universidad.

CASAldUERo, J. (1972). Estudios sobre el teatro español. Madrid: Gredos, $3 .^{\mathrm{a}}$ ed.

- (1974). «El teatro en el siglo XIX». En Historia de la literatura española, J. M. ${ }^{\text {a }}$ Díez Borque (ed.), III, 133-162. Madrid: Guadiana.

Castellón, A. (1994). El teatro como instrumento político en España, 1895-1914. Madrid: Endymión (Prólogo de Ricardo Doménech).

Chu-Pund, O. (1991). La figura del Mesías en el teatro romántico español. San José de Costa Rica: Fundación San Judas Tadeo.

Cook, J. A. (1959). Neo-Classic Drama in Spain. Theory and Practice. Dallas: South Methodist University Press.

COTARELO Y MORI, E. (1897-1902). Estudios sobre la historia del arte escénico en España. Madrid: s.e., 2 vols.

- (1904). Bibliografía de las controversias sobre la licitud del teatro en España. Madrid: RABM.

CRESPO MATElláN, S. (1979). La parodia dramática en la literatura española (Esbozo de una historia de la parodia dramática en la literatura española...). Salamanca: Universidad.

CROCE, E. (1986). Il Romanticismo spagnolo. La splendida eredità di un Romanticismo povero. Roma: Bulzoni.

Deleito y Piñuela, J. (s. a.). Estampas del Madrid teatral fin de siglo. I. Español. Comedia. Princesa. Novedades. Lara. Madrid: Saturnino Calleja.

Df́az dE Escovar, N. (s. a.). Siluetas escénicas del pasado. Colección de artículos históricos de costumbres, anécdotas, biografías, bibliografía, etcétera, del teatro español. Barcelona: Viuda de Luis Tasso.

Díaz de Escovar, N. y LASSo de la VeGa, F. de P. (1924). Historia del teatro español. Comediantes. Escritores. Curiosidades escénicas. Barcelona: Montaner y Simón, 2 vols. 
UNA BIBLIOGRAFÍA (SELECTA) PARA LA RECONSTRUCCIÓN DE LA VIDA ESCÉNICA...

Díaz-Plaja, F. (1993). Vida cotidiana romántica. Madrid: EDAF.

Díaz-Plaja, G. (1952). La vida española en el siglo XIX. Madrid: Aguado.

- (1963). «Perfil del teatro romántico español». Estudios Escéni$\cos$ VIII, 31-56.

DíEz Taboada, J. M. ${ }^{\text {a }}$ (1985). «Das spanische Theatrer des 19. Jahrhunderts». En Das Spanische Theater. Von den Anfängen bis zum Ausgang des 19. Jahrhunderts, K. Pörtl (ed.), 392-473. Darmstadt: Wissenschaftliche Buchgesellsechaft.

Díez TABoAda, J. M. ${ }^{\text {a }}$ et alii (1997). «El teatro (II)». En Historia de la literatura española. Siglo XIX (I), V. García de la Concha (ed.) y G. Carnero (coord.), t. 8, 291-431. Madrid: Espasa Calpe.

DURÁN, A. (1994). Discurso sobre el influjo que ha tenido la crítica moderna en la decadencia del teatro antiguo español, y sobre el modo con que debe ser considerado para juzgar convenientemente de su mérito popular. Málaga: Ágora (edición de D. L. Shaw). [1. ${ }^{a}$ ed. 1828.]

ENTRAMBASAguAS, J. de (1939). La determinación del Romanticismo español y otras cosas (Ensayos). Barcelona: Apolo.

EsCOBAR, J. (1993). «Ilustración, Romanticismo, Modernidad». En EntreSiglos, E. Caldera y R. Froldi (eds.), 123-133. Roma: Bulzoni.

Espín Templado, M. ${ }^{a}$ P. (1995). El teatro por horas en Madrid (18701910). Madrid: Instituto de Estudios Madrileños / Fundación Jacinto e Inocencio Guerrero.

FÁBREGAS, X. (1969). Teatre català d'agitaciò politica. Barcelona: Edicions 62.

- (1972). Aproximació a la historia del teatre català modern. Barcelona: Curial.

- (1978). Historia del teatre català. Barcelona: Millà.

FERNÁNDEZ EsPINo, J. (1871). Curso histórico-crítico de la literatura española. Sevilla.

FERRER DEL Río, A. (1846). Galería de la literatura española. Madrid: Establecimiento Tipográfico de Francisco de Paula Mellado.

Ferreras, J. I. y Franco, A. (1989). El teatro en el siglo XIX. Madrid: Taurus. 
FLITTER, D. (1995). Teoría y crítica del Romanticismo español. Cambridge: Cambridge University Press.

Flores García, F., Górcholis (s. a.). Memorias íntimas del teatro. Valencia: F. Sempere y Compañía.

- (1913). Recuerdos de la Revolución (Memorias íntimas). Madrid: Ruiz Hermanos Editores.

FonT, M. (1928). El teatre català anterior a Pitarra. Barcelona: Barcino.

García Castañeda, S. (1971). La ideas literarias en España entre 1840 y 1850. Berkeley, California: University of California Press.

García de VillanueVA, Manuel (1802). Origen, épocas y progresos del teatro español: discurso histórico. Madrid: Sancha.

García Pavón, F. (1962). El teatro social en España (1895-1962). Madrid: Taurus.

García Templado, José (1991). El teatro romántico. Madrid: Anaya.

Garrido Palazón, M. (1992). La filosofía de las Bellas Letras y la historia literaria en España (1777-1844). Almería: Instituto de Estudios Almerienses.

GIEs, D. T. (1988). Theatre and Politics in 19th Century Spain: Juan de Grimaldi as Impresario and Government Agent. Cambridge: Cambridge University Press.

- (1996). El teatro en la España del siglo XIX. Cambridge: Cambridge University Press (Traducción de Juan Manuel Seco). [Traducción de The Theatre in Nineteenth Century Spain. Cambridge: Cambridge University Press, 1994.]

GIES, D. T., ed. (1989). El Romanticismo. Madrid: Taurus.

GIL y ZÁrate, A. (1844). Manual de literatura. Madrid: Boix, 2 vols.

Goenaga, A. y Maguna, J. P. (1971). Teatro español del siglo XIX. Análisis de obras. Nueva York: La Américas. [Salamanca: Anaya, 1972.]

GUERRERO ZAMORA, J. (1961-1967). Historia del teatro contemporáneo. Barcelona: Juan Flors Editor, 4 vols. [Vol I (1961), II (1961), III (1962) y IV (1967).]

JURETSCHKE, H. (1965-66). «El teatro español y el Romanticismo alemán». Filologia e Letteratura 21-22, 59-73. 
LARRA, F. J. de (1947). La sociedad española a través del teatro del siglo XIX. Madrid: Ministerio de Trabajo-Escuela Social de Madrid.

LARRAZ, M. (1987). La guerre d'Indepéndence espagnole et le théâtre: 1808-1814. Anthologie. Aix-en-Provence: Université.

- (1988). Théâtre et politique pendant la guerre d'Independence espagnole: 1808-1814. Aix-en-Provence: Université. [Thèse de Doctorat d'État.]

LESLIE, J. (1940). Ventura de la Vega and Spanish Theatre 1820-1855. Princeton: Princeton University Press.

LisTA, A. (1844). Ensayos literarios y críticos. Sevilla: Calvo Rubio, 2 vols.

LITVAK, L. (1981). Musa libertaria. Barcelona: A. Bosch.

LLORENS, V. (1979). El romanticismo español. Madrid: Fundación Juan March-Castalia.

Lomba y PedRAJA, J. R. (1936). «El teatro romántico español». En Mariano José de Larra (Fígaro). Cuatro estudios que lo abordan o le bordean. Madrid: Tipografía de Archivos.

LÓPEZ JIMÉNEZ, L. (1977). El Naturalismo en España. Madrid: Alhambra.

LyONNET, H. (1897). Le théâtre en Espagne. París: Paul Ollendorf.

MARCO REVILLA, J. (1977). Literatura popular en España en los siglos XVIII y XIX. Madrid: Taurus, 2 vols.

MARTIN, G. C. (1985). «Querer y no poder, o el teatro español de 1825 a 1836». En Studies in Eighteenth Century Spanish Literature and Romanticism in Honor John C. Dowling, D. y L. J. Barnette (eds.), 123-131. Newark: Juan de la Cuesta.

MARTín FERNÁNDEZ, M. ${ }^{a}$ I. (1978). «El lenguaje arcaizante de los dramaturgos posrománticos». Anuario de Estudios Filológicos (Cáceres) $1,91-117$.

- (1980). El lenguaje retórico de los dramaturgos posrománticos. Cáceres: Universidad de Extremadura.

Martínez Espada, M. (1900). Teatro contemporáneo. Apuntes para un libro de crítica. Madrid: Ducázcal. 
Martínez Olmedilla, A. (1908). Memorias de un afrancesado. Madrid: Librería Pueyo.

- (1952). Nuevas memorias de un afrancesado. Madrid: Sáez.

- (1957). Anecdotario del siglo XIX. Madrid: Aguilar.

MARTínez TORRón, D. (1993). El alba del Romanticismo español. Sevilla: Alfar.

MCClelland, I. (1970). Spanish Drama of Pathos, 1750-1800. Liverpool: Liverpool University Press.

MembreZ, N. J. (1987). The "Teatro por horas»: History, Dynamics and Comprehensive Bibliography of a Madrid Industry (18671922). Santa Bárbara: Diss. University of California, 3 vols.

Méndez Bejarano, M. (1921). La literatura española en el siglo XIX. Madrid: Gráfica Universal.

MENARINI, P. et alii (1982). El teatro romántico español (1830-1850). Autores, obras, bibliografía. Bolonia: Atesa Editrice.

Mesonero Romanos, R. (1967). Obras. Madrid: Atlas (BAE, CXCIX-CCIII). Edición de Carlos Seco Serrano.

- (1971). «Rápida ojeada sobre la historia del teatro español. Época actual (1842)». En El Romanticismo español. Documentos, R. Navas-Ruiz, 303-315. Salamanca: Anaya.

- (1994). Memorias de un setentón. Madrid: Castalia / Comunidad de Madrid (Edición de José Escobar y Joaquín Álvarez Barrientos).

Morley, S. G. (1948). «The curious Phenomenon of Spanish Verse Drama». Bulletin Hispanique 50, 445-462.

Navas RuIz, R. (1971). El Romanticismo español. Documentos. Salamanca: Anaya.

- (1982). El Romanticismo español. Madrid: Cátedra, $2 .^{a}$ ed.

Palmerín De Oliva [seudónimo del autor y crítico Luis Ruiz Contreras] y EL AMIGO FRITZ (1891). Dramaturgia castellana. Estudio acerca del Teatro Nacional. Madrid: Sáenz de Jubera.

Pataky-Kosove, J. L. (1977). The "comedia lacrimosa» and Spanish Romantic Drama. Londres: Tamesis Books. 
Peak, J. H. (1964). Social Drama in Nineteenth-Century Spain. Chapell Hill: University of North Carolina Press.

PeERs, E. A. (1954). Historia del movimiento romántico español. Madrid: Gredos, 2 vols.

Pérez-Bustamante Mourier, A. S. et alii, eds. (1995). El siglo XIX... Y la burguesía también se divierte (Actas del I Congreso de Historia y Crítica del teatro de comedias). El Puerto de Santa María: Fundación Pedro Muñoz Seca / Ayuntamiento.

PÉRez DE CAPO, F. (s. a.). Treinta y tres años de teatro (1886-1918). Barcelona: Imprenta Borrás.

PÉREZ y GonZÁleZ, F. (1904). Teatralerías (Casos y cosas teatrales de antaño y hogaño). Madrid.

Pleyán, C., ed. (1946). Teatro romántico (Selección, introducción y notas). Barcelona: Rauter.

PiñeYro, E. (1904). El Romanticismo en España. París: Garnier.

ReVILla, M. de la y GaRCÍA, P. (1877). Principios generales de literatura e historia de la literatura española. Madrid: Librerías de Francisco Iravedra y Antonio Novo, 2 vols.

ReYES, M. A. (1983). «The Spanish Romantics and Theatre as a Visual Art». En Stating in the Spanish Theatre, 27-48. Leeds: Trinity and All Saints' College.

Ríos Carratalá, J. A. (1986-87). «Versiones decimonónicas de la leyenda de la Judía de Toledo». Anales de Literatura Española de la Universidad de Alicante 5, 425-436.

RodrígueZ, J. C. (1984). «Escena árbitro / estado árbitro (Notas sobre el desarrollo del teatro desde el siglo XVIII a nuestros días». En su obra, La norma literaria, 124-192. Granada: Diputación Provincial.

RODRÍGUEZ RUBÍ, T. (1860). Excelencia, importancia y estado presente del teatro. Madrid.

Rogers, P. P. (1933). «Dramatic Copyright in Spain before 1850». The Romanic Review XXV, 35-39.

Romera Castillo, J. (1993). «Teatro regional español en el siglo XIX (Bibliografía)». En Ex Libris. Homenaje al profesor José Fradejas Lebrero, José Romera, Antonio Lorente y Ana M. ${ }^{a}$ Freire (eds.), II, 705-718. Madrid: UNED. 
- (1998). «El personaje en escena (Un método de estudio)». En Theatralia II. El personaje teatral, Jesús G. Maestro (ed.), 77108. Vigo: Universidade.

ROMERO TOBAR, L. (1970). La teoría dramática española: 1800-1870. Madrid: Facultad de Filosofía y Letras de la Universidad Complutense. [Resumen de la tesis de doctorado.]

- (1973). «Prosa y teatro románticos». En Literatura española en imágenes. Madrid: La Muralla, vol. 21 (42 págs. + 60 diapositivas).

- (1994). Panorama crítico del romanticismo español. Madrid: Castalia. [Cap. V: «El teatro Romántico».]

ROSENBERG, J. R., ed. (1988). Resonancias románticas: evocaciones del Romanticismo hispánico. Madrid: Porrúa.

Rubio JiMÉneZ, J. (1982). Ideología y teatro en España: 1890-1900. Zaragoza: Departamento de Literatura de la Universidad de Zaragoza / Libros Pórtico.

- (1983). El teatro en el siglo XIX. Madrid: Playor.

- (1988). «El teatro en el siglo XIX (II) (1845-1900)». En Historia del teatro en España, II, J. M. ${ }^{a}$ Díez Borque (ed.), 625-762. Madrid: Taurus.

Ruiz Contreras, L. (1891). Dramaturgia castellana. Madrid.

- (1894). Desde la platea. Divagaciones y críticas. Madrid: Fernando Fe.

Ruiz Ramón, F. (1979). Historia del teatro español (Desde sus orígenes hasta 1900). Madrid: Cátedra.

RUIZ RoMERo, I. (1996). El teatro español (1860-1882): Teoría y critica. Barcelona: Universidad de Barcelona (Tesis de doctorado, bajo la dirección de Adolfo Sotelo).

SÁINZ DE RoBles, F. C. (1943). El teatro español. Historia y antología desde el siglo XV al XIX (Edición e introducción). Madrid: Aguilar, vol. 7.

- (1966). El espíritu y la letra (Cien años de literatura española, 1860-1960). Madrid: Aguilar. 
UNA BIBLIOGRAFÍ (SELECTA) PARA LA RECONSTRUCCIÓN DE LA VIDA ESCÉNICA...

SAlVAT, R. (1981). Historia del teatro moderno, I. Barcelona: Península.

SAN VICENTE, F. (1984). «El mensaje sin secreto. Tipología del título en el teatro español (1830-1850)». Quaderni di Filologia e Lingue Romanze (Macerata) 4, 91-133.

SÁNChEZ, R. G. (1974). El teatro en la novela. Galdós y Clarín. Madrid: Ínsula.

SÁNCHEZ MARIANA, M. (1986). «Documentos para la historia del teatro español en la sección de manuscritos de la Biblioteca Nacional». En Homenaje a Luis Morales Oliver. Madrid: Española.

- (1998). «La crítica literaria: las ediciones del teatro». En Historia de la literatura española. Siglo XIX (II), V. García de la Concha (ed.) y L. Romero Tobar (coord.), t. 9, 862-864. Madrid: Espasa Calpe.

Sebold, R. P. (1983). Trayectoria del Romanticismo español. Desde la Ilustración hasta Bécquer. Barcelona: Crítica.

SENABRE, R. (1998). «La creación de un mito cultural: El teatro nacional español». En Mitos. Actas del VII Congreso Internacional de la Asociación Española de Semiótica, Túa Blesa (ed.), vol. I, 9094. Zaragoza: Facultad de Filosofía y Letras (Anejos Tropelías, 4).

Sepúlveda, R. (1888). El Corral de la Pacheca (Apuntes para la historia del teatro español). Madrid: Fernando Fe.

Simón DíAz, J. (1980). Manual de bibliografía de la literatura española, 589-607. Madrid: Gredos. [Epígrafe: «Siglo XIX. Fuentes generales».]

Simón PALMER, M. ${ }^{\text {a C}}$. (desde 1976-hasta hoy). Repertorios bibliográficos, referidos al «Siglo XIX. Fuentes generales», que aparecen al final de la Revista de Literatura (Madrid: CSIC).

Soто, J. L. (1969). Un siglo de historia literaria (1862-1962), con apéndice (1963-1969). Santiago de Compostela.

SUBIRÁ, J. «La Junta de Reforma de Teatros: sus antecedentes, actividades y consecuencias». Revista de Bibliotecas, Archivos y Museos IX, 19-45.

TALMA, F.-J. (1879). Reflexiones sobre el arte teatral, vertidas al castellano por Enrique Sánchez de León. Madrid: Montoya.

TORRENTE BALlester, G. (1968). Teatro español contemporáneo. Madrid: Guadarrama. 
UNAMUNo, M. de (1896). «La regeneración del teatro español». La España Moderna XCI, 5-36.

Valbuena Prat, A. (1944). Teatro moderno en España. Zaragoza: Partenón.

- (1956). Historia del teatro español. Barcelona: Noguer.

VALERA, J. (1864). Estudios críticos sobre literatura, política y costumbres de nuestros días. Madrid: A. Durán. [Otra edición en Sevilla / Madrid: Francisco Álvarez y Cía., 1884, vol. II, 309-344.]

VALlADARES y SAAVEDRA, R. de (1848). Nociones acerca de la historia del teatro, desde su nacimiento hasta nuestros días, antecediéndola algunos principios de poética, música y declamación. Madrid: Rivadeneyra.

VALVERDE, J. M. ${ }^{a}$ (1975). «Del Romanticismo a nuestros días». En Historia de la literatura universal, M. de Riquer y J. M. ${ }^{a}$ Valverde (eds.), t. 3, 243 y ss. Barcelona: Planeta, 5. ${ }^{\mathrm{a}} \mathrm{ed}$.

VV.AA. (1876). «Ateneo de Madrid. Sección de Literatura y Bellas Artes. [Discusión sobre el tema: "¿Se halla en decadencia el teatro español? Si se halla ¿por qué medios pudiera procurarse su regeneración?"]». Revista Europea VII, 237-239, 274-277 y 546-547.

- (1978). Romantisme, Réalisme, Naturalisme en Espagne et en Amérique Latine. Lille: Université.

- (1979). «El teatre al tombant de segle (1874-1909)». L'Avenç $22,17-40$.

- (1982). Atti del II Congresso sul Romanticismo spagnolo e ispanoamericano (Aspetti e problemi del teatro romantico) (Génova: Facoltà di Magistero; Biblioteca di Letteratura). Romanticismo 1.

- (1984a). Atti del III Congresso sul Romanticismo spagnolo e ispanoamericano. Il linguaggio romantico (Génova: Facoltà di Magistero; Biblioteca di Letteratura). Romanticismo 2.

- (1984b). Teatro romantico spagnolo. Autori, personaggi, nuovi analisi. Bolonia: Pàtron Editore (Quaderni di Filologia Romanza, 4).

- (1988). Atti del IV Congresso sul Romanticismo spagnolo e ispanoamericano (Génova: Facoltà di Magistero; Biblioteca di Letteratura). Romanticismo 3-4. 
- (1991). Théâtre et spectacles hier et aujourd'hui. Époque modérne et contemporaine (Actes du $115 \mathrm{e}$ Congrés National des Societés Savantes). París: Éditions du Comité des Travaux Historiques et Scientifiques.

Velilla, J. (1876). El teatro en España. Sevilla.

YXART, J. (1889). El año pasado. Letras y artes en Barcelona. Barcelona: Librería Española.

- (1894-1896). El arte escénico en España. Barcelona: La Vanguardia, 2 vols. [Reedición en Barcelona: Alta Fulla, 1987.] [Nota: En Tarragona, en noviembre de 1995, se celebró un Col.loqui sobre Josep Yxart i el seu temps, que será editado por el Institut d'Estudis Tarraconenses.]

ZAVALA, I. M., ed. (1982). «La fortuna del teatro romántico» (183-238) y «Teatro y poesía naturalistas» (623-662). En Historia y crítica de la literatura española, F. Rico (ed.), vol. 5. Barcelona: Crítica.

ZoRrIlla, J. (1943). Recuerdos del tiempo viejo. En Obras Completas. Valladolid: Santarén. [Otra edición en Madrid: Publicaciones Españolas, 1961, 2 vols.]

\section{II.2. Historias de la literatura española (selección)}

AlboRg, J. L. (1980). Historia de la literatura española. El Romanticismo. Madrid: Gredos, tomo IV. [Cf. además el tomo V, recientemente aparecido.]

AMADOR DE LOS Rf́os, J. (1861-1865). Historia crítica de la literatura española. Madrid: Imprenta de José Rodríguez y Muñoz, 7 vols. [Edición facsímil en Madrid: Gredos, 1969.]

ANDRÉs, J. (1784-1806). Origen, progresos y estado actual de toda la Literatura. Madrid: Sancha, 10 vols.

AUB, M. (1974). Manual de historia de la literatura española. Madrid: Akal.

Blanco Garcí, F. (1891-1894). La literatura española en el siglo XIX. Madrid: Sáez de Jubera, 3 vols. [2. ${ }^{a}$ ed.: 1899-1904; 3. ${ }^{\mathrm{a}}$ ed.: 1909-1912.] 
CEJADOR Y FRAUCA, J. (1915-1922). Historia de la Lengua y la Literatura Castellanas. Madrid: Tip. de la Revista de Archivos. [Facsímil, Madrid: Gredos, 1972, tomos VIII y IX.]

CONDE DE SCHACK [Adolfo Federico] (1885-1887). Historia de la literatura y del arte dramático en España. Madrid: M. Tello, 5 vols. (Traducción de Eduardo de Mier).

Díaz-Plaja, G., ed. (1969). Historia general de las literaturas hispánicas, t. IV y V. Barcelona: Vergara.

Dízz BorQue, J. M. ${ }^{\text {a }}$, ed. (1980a). Historia de la literatura española. Madrid: Taurus, tomo III.

- (1980b). Historia de las literaturas hispánicas (no castellanas). Madrid: Taurus.

Díz Echarri, E. y Roca Franquesa, J. M. ${ }^{\text {a }}$ (1972). Historia de la literatura española e hispanoamericana. Madrid: Aguilar, 2. ${ }^{\mathrm{a}} \mathrm{ed}$.

García de la Concha, V. (ed.) y CARnero, G. (coord.) (1997). Historia de la literatura española. Siglo XIX (I), t. 8. Madrid: Espasa Calpe.

GaRcía de la Concha, V. (ed.) y Romero Tobar, L. (coord.) (1998). Historia de la literatura española. Siglo XIX (II), t. 9. Madrid: Espasa Calpe.

González Herrán, J. M. y Penas Varela, E. (1992). Cronología de la literatura española. Siglos XVIII y XIX, t. III. Madrid: Cátedra.

HAMILTON, C. (1963). La literatura del siglo XIX. Nueva York: Holt, Rinehart, Winston.

Hurtado, J. y González Palencia, A. (1921). Historia de la literatura española. Madrid: Tipografía de la Revista de Archivos, Bibliotecas y Museos. [Madrid: SAETA, 1949, 6. $\left.{ }^{\mathrm{a}} \mathrm{ed}.\right]$

MÉNDeZ BejaRANO, M. (1921). La literatura española en el siglo XIX (general, regional y americana). Madrid.

Pedraza Jiménez, F. y Rodríguez Cáceres, M. (1983). Manual de literatura española. VII. Época del Realismo. Tafalla: Cénlit, pág. 213-314.

- (1986). Manual de Literatura española. VIII. Generación de fin de siglo: Introducción, líricos y dramaturgos. Tafalla: Cénlit. 
UNA BIBLIOGRAFIA (SELECTA) PARA LA RECONSTRUCCIÓN DE LA VIDA ESCÉNICA...

RAGUCCI, R. M. (1962). Literatura española de los últimos cien años (desde 1850). Buenos Aires: Edit. Don Bosco.

Rico, F., ed. (1982). Historia y Crítica de la Literatura Española. Barcelona: Crítica, tomo 5.

Río, Á. del (1963). Historia de la literatura española. Nueva York: Hotl, Rinehart and Winston. [Ed. ${ }^{\circ}$ revisada.]

SANTA, Á. (1994). «Siglo XIX: el teatro». En Historia de la literatura francesa, Javier del Prado (ed.), 1.003-1.041. Madrid: Cátedra.

ScHACK, Conde de [Adolfo Federico] (1885-1887). Historia de la literatura y del arte dramático en España. Madrid: M. Tello / CEC, 5 vols. (Traducción de Eduardo de Mier).

SHAw, D. L. (1973). Historia de la literatura española. El siglo XIX. Barcelona: Ariel, tomo 5.

TICKNOR, G. (1849). History of Spain Literature. Nueva York, 3 vols. [Con edición traducida y añadida de Pascual Gayangos y Enrique de Vedia, Madrid, 1851-1856, 4 vols.]

Valbuena Prat, A. (1964). Historia de la literatura española. Barcelona: Gustavo Gili, t. III, cap. LXIV especialmente.

ZaVAla, I. M., ed. (1998). Breve historia feminista de la literatura española (en lengua castellana), vol. V: La literatura escrita por mujer. Desde el siglo XIX hasta la actualidad. San Juan de Puerto Rico / Barcelona: Universidad de Puerto Rico / Anthropos.

\section{SOBRE DRAMATURGOS ${ }^{9}$}

Adams, N. B. (1922). The Romantic Dramas of García Gutiérrez. Nueva York: Instituto de España.

AgUilar PIÑAL, F. (1976). Bibliografía fundamental de la literatura española. Siglo XVIII. Madrid: Sociedad General Española de Librería.

9 Constatar una bibliografía exhaustiva sobre los dramaturgos sería una labor que excede los límites de este trabajo. Por ello, solamente realizaré una selección de libros muy generales - más algunos (pocos) artículos- sobre diversos autores. 
- (1981-1995). Bibliografía de autores españoles del siglo XVIII. Madrid: CSIC, 8 vols. [I: A-B (1981); II: C-Ch (1983); III: D-F (1984); IV: G-K (1986); etc.]

- (1987). Un escritor ilustrado: Cándido M. ${ }^{a}$ Trigueros. Madrid: CSIC.

Alcalá Galiano, A. (1886). Memorias. Madrid: Rubiños.

AlCÁzAR Simón, M. ${ }^{a}$ A. (1996). La obra teatral de José Jackson Veyán (paradigma del género chico). Madrid: UNED (Memoria de Investigación dirigida por M. ${ }^{a}$ Pilar Espín Templado).

Alonso CoRTÉs, N. (1917-1920). Zorrilla. Su vida y sus obras. Valladolid: Ayuntamiento, 3 vols. [Otra edición en Valladolid: Santarén, 1943.]

ANónIMo (1933a). Rosario de Acuña en la Escuela. Madrid: De Lamo Hermanos.

- (1933b). ¿Quién fue Rosario de Acuña? Madrid: Artes Gráficas Municipales.

ARDERfUS, F. (1914). De mis recuerdos. Narraciones históricas. Madrid.

Ávila Arellano, J. y Menéndez OnRubia, C. (1987). El Neorromanticismo español y su época. Epistolario de José Echegaray a María Guerrero. Madrid: CSIC.

AzORIN (1947). Rivas y Larra. En sus Obras completas, II. Madrid: Aguilar.

BALlew, H. L. (1957). The Life and Works of Dionisio Solis. Chapell Hill: University of North Carolina.

BARCEló JIMÉneZ, J. (1956). Vida y obra de Federico Balart. Murcia: Diputación.

BARJA, C. (1933). Literatura española. Libros y autores modernos. Siglos XVIII y XIX. Los Angeles: Campbell's Books Store. [Otra edición en Nueva York: Las Américas, 1964, 2. ${ }^{\mathrm{a}}$ ed.]

Bastinos, J. A. (1914). Arte dramático español contemporáneo. Bosquejo de autores y artistas que han sobresalido en nuestro teatro. Barcelona: Imprenta Elzeviriana.

BENAVENTE, J. (1958). Recuerdos y olvidos. En Obras completas, XI. Madrid: Aguilar. 
Benftez, R., ed. (1979). Mariano José de Larra. Madrid: Taurus.

BENSOussan, A. (1982). José Yxart (1852-1895). Théâtre et critique à Barcelone. Lille: Université de Lille III, 2 vols.

Bensoussan, M. (1993). «El teatro de aficionados de Narcís Oller». Lenguaje y Textos 3, 81-89.

BESER, S. (1960). «Siete cartas de Leopoldo Alas a José Yxart». Archivum 10, 385-397.

- (1966). «Índices de colaboraciones de Leopoldo Alas en la prensa barcelonesa». Archivum 16, 157-211.

- (1968). Leopoldo Alas, crítico literario. Madrid: Gredos.

Blanco, A. (1989). «Domesticity, Education and the Woman Writer: Spain 1850-1880». En Cultural and Historical Grounding for Hispanic and Luso-Brazilian Feminist Criticism, H. Vidal (ed.), 371394. Minneapolis, Minnesota: Institute for the Study of Ideologies and Literature.

Blasco, E. (1880). Malas costumbres. Apuntes de mi tiempo seguidos de algunos bocetos biográficos y poesías. Madrid: Oficinas de La Ilustración Española y Americana.

- (1886). Mis contemporáneos. Madrid. [Reimpresión en Obras Completas, Madrid, 1903-1906, vol. XIII.]

- (1894). Recuerdos: notas íntimas de Francia y España. Madrid: Fernando Fe.

- (1904). Memorias intimas. En Obras Completas, vol. IV. Madrid.

Blasco, J. et alii, eds. (1995). Actas del Congreso sobre José Zorrilla. Una nueva lectura. Valladolid: Universidad / Fundación Jorge Guillén.

Bonet, L. (1983). Literatura, regionalismo, lucha de clases: Pereda, Narcís Oller, Ramón D. Perés. Barcelona: Universidad de Barcelona.

BOTREL, J.-F. (1974). «Sobre la condición del escritor en la España del siglo XIX: la constitución de la Asociación de Escritores y Artistas Españoles (1872-1877)». En Movimiento obrero, política y literatura en la España contemporánea, VV. AA., 179-210. Madrid: Edicusa $\left[4 .^{\circ}\right.$ Coloquio de Pau.] 
Bravo-Villasante, C. (1967). Una vida romántica. La Avellaneda. Barcelona: Edhasa.

Burgos, A. M. ${ }^{a}$ (1963). «Vida y obra de Tomás Rodríguez Rubí». Revista de Literatura XXIII, 65-104.

CÁCERES SÁNCHEZ, M. (1991). El almeriense Álvarez de Sotomayor (1880-1947) y la literatura rural en España. Almería: Instituto de Estudios Almerienses.

Caldera, E. (1990a). «Bretón o la negativa del modelo». Cuadernos de Teatro Clásico 5, 141-153.

- (1990b). «La perspectiva femenina en el teatro de Joaquina García Balmaseda y Enriqueta Lozano». En Escritoras románticas españolas, M. Mayoral (ed.). Madrid: Fundación Banco Exterior.

Calvo Aguilar, I. (1954). Antología biográfica de escritoras españolas. Madrid: Biblioteca Nueva.

CARBO, F. et alii (1997). Escalante i el teatre del segle XIX (precedents i pervivència). Barcelona: Publicacions de l'Abadia de Montserrat.

CARdwell, R. y LANDEIRA, R., eds. (1993). José Zorrilla, 1893-1993. Notthingham: University Press.

CARnero, G. (1989). «Recursos y efectos escénicos en el teatro de Gaspar Zavala y Zamora». Bulletin Hispanique 91.1, 21-36.

- (1990). «Francisca Ruiz de Larrea y el inicio gaditano del Romanticismo español». En Escritoras románticas españolas, Marina Mayoral (ed.), 119-130. Madrid: Fundación Banco Exterior.

CARNICER, R. (1969). Entre la ciencia y la magia. Mariano Cubí (En torno al siglo XIX español). Barcelona: Seix-Barral.

CAsalduero, J. (1961). Espronceda. Madrid: Gredos.

- (1962). Vida y obra de Galdós. Madrid: Gredos.

Castañón, L. (1986). «Aportación a la biografía de Rosario de Acuña». Boletín del Instituto de Estudios Asturianos XL, 167-169. [Sobre Rosario de Acuña (1851-1923).]

CAzorla, H. (1989). «Larra, crítico y creador teatral, en busca del héroe». Hispania LXXII.3, 491-497.

Córdoba, D. (1934). Some Aspects of the Dramatic Art of Narciso Serra. University of Carolina (Tesis de doctorado). 
Correa Calderón, E. (1974). «Larra, crítico de teatro». Revista de Ideas Estéticas XXXII, 191-212.

COTARElo y MoRI, E. (1897). Iriarte y su época. Madrid: Sucesores de Rivadeneyra.

- (1899). Don Ramón de la Cruz y sus obras. Ensayo biográfico y bibliográfico. Madrid: Imprenta de José Perales y Martínez.

Couglhin, E. V. (1977). Adelardo López de Ayala. Boston: Twayne Publishers Company.

CRIADO Y DomíngueZ (1889). Literatas españolas del siglo XIX. Madrid: Pérez Dubrull.

Curzon, H. de (1912). Le théâtre de José Echegaray. París: Fischbacher.

DAVIES, C. (1998). Spanish Women's Writing 1849-1996. Londres \& Atlantic Highlands, N.J.: The Atholone Press.

Delgado, S. (1905). Mi teatro. Madrid: Hijos de M. G. Hernández. [Reeedición en Madrid: S.G.A.E., 1960, en el centenario de su nacimiento.]

DÉROZIER, A. (1975). Escritores políticos españoles (1789-1854). Madrid: Turner.

DÍAZ DE Escovar, N. (1916). Intimidades de la farándula. Colección de artículos referentes a la escena, comediantes y escritores dramáticos desde el siglo XVI hasta el día. Cádiz: Editorial España y América.

Díaz de Escovar, N. y LASSo de LA VeGA, F. (1924). Historia del teatro español. Comediantes. Escritores. Curiosidades escénicas. Barcelona: Montaner y Simón, 2 vols.

Diccionario Enciclopédico Hispano-americano de Literatura, Ciencias y Artes. Barcelona: Montaner y Simón, numerosos tomos. [El primero, 1896.]

Díez DE ReVenga, F. J. y DE PACo, M., eds. (1987). Estudios sobre Vicente Medina. Murcia: Academia Alfonso X el Sabio.

DOMÉNECH, F. (1996). Teatro breve de mujeres. Siglos XVII-XX. Madrid: Asociación de Directores de Escena de España.

DURÁN LÓPEZ, F. (1997). Catálogo comentado de la autobiografía española (Siglos XVIII y XIX). Madrid: Ollero \& Ramos. 
ECHEGARAY, J. (1917). Recuerdos. Madrid, 3 vols. [Publicados en las revistas La España Moderna (1894-97) y El Madrid científico. Reimpresión en Madrid, 1949.]

ElíAS DE Molins, A. (1889). Diccionario biográfico y bibliográfico de escritores y artistas catalanes del siglo XIX. Barcelona, 2 vols. [Edición facsímil en Hildesheim / Nueva York: Georg Olms Verlag, 1972.]

Escobar, A. (Marqués de Valdeiglesias) (1949). 70 años de periodismo. Memorias. Madrid: Biblioteca Nueva, 2 vols.

Escobar, J. (1973). Los orígenes de la obra de Larra. Madrid: Prensa Española.

- (1976). «Un episodio biográfico de Larra. Crítico teatral en la temporada de 1834». Nueva Revista de Filología Hispánica XXV, 45-72.

EsGuEVA, M. (1977). «Bibliografía de José Echegaray». En Jornadas de Orientación Bibliográfica, VV. AA., 197-212. Madrid: Fundación Universitaria Española.

Espín TeMPLADo, M. ${ }^{\text {a }}$ P. (1995). El teatro por horas en Madrid (18701910). Madrid: Instituto de Estudios Madrileños / Fundación Jacinto e Inocencio Guerrero.

Espina y Calvo, A. (1926). Notas del viaje de mi vida (1850-1920). Madrid: Espasa-Calpe.

ESQUER TORRES, R. (1965). El teatro de Tamayo y Baus. Madrid: CSIC.

FÁBREGAS, X. (1971). Ángel Guimerà: les dimensions d'un mite. Barcelona: Edicions 62.

FERNÁNDEZ BREMON, J. (1882). Autores dramáticos contemporáneos. Madrid: Forfanet.

FERNÁNDEZ CABEZón, R. (1984). Lances y batallas: Gaspar Zavala y Zamora y la comedia heroica. Valladolid: Aceña.

Fernández de CóRdobA, F. (Marqués de Mendigorría). Mis memorias intimas. Madrid: B.A.E., t. 193. [Hay otras ediciones.]

FERNÁNDEZ de MoRATín, L. (1967). Diario (Mayo 1780-Marzo 1808). Madrid: Castalia (Edición de René y Mireille Andioc).

- (1973). Epistolario. Madrid: Castalia. 
FERNÁNDEZ-GUERRA, A. (1882). Hartzenbusch, estudio biográfico crítico. Madrid: Imprenta de la Compañía de Impresores y Libreros.

FERRERAS, J. I. (1979). Catálogo de novelas y novelistas del siglo XIX. Madrid: Cátedra. [Para adaptaciones teatrales.]

FERRERES, R. (1967). Eduardo Escalante, el hombre y su obra. Valencia: Prometeo.

Finkenthal, S. (1980). El teatro de Galdós. Madrid: Fundamentos.

FloRes GARCÍA, F. (1879). Galería de tipos, retratos y cuadros de costumbres. Madrid: Librería J. Rodríguez.

FLYNN, G. (1973). Manuel Tamayo y Baus. Boston: Twayne.

- (1976). «Una bibliografía anotada sobre Manuel Bretón de los Herreros». Berceo 91, 167-193.

- (1978). Manuel Bretón de los Herreros. Boston: Twayne.

- (1980). «Las cartas íntimas de Ventura de la Vega». En Actas del VI Congreso de la Asociación Internacional de Hispanistas, 255-257. Toronyo: University of Toronto.

Fornielles AlCARAz, J. (1989). Trayectoria de un intelectual de la Restauración: José Echegaray. Almería: Caja Almería.

Fradejas Lebrero, J. (1987). Antonio Ros de Olano. Madrid: Ayuntamiento.

- (1994). Narciso Serra (mi calle). Madrid: Ayuntamiento / Instituto de Estudios Madrileños.

- (1995). Narciso Serra, poeta y dramaturgo. Madrid: Ayuntamiento / Instituto de Estudios Madrileños.

GARCÍA BARRÓN, C. (1987). Vida, obra y pensamiento de Manuel de la Revilla. Madrid: Porrúa.

GARCía PEREs, D. (1890). Catálogo razonado de los escritores portugueses que escribieron en castellano. Madrid.

Garelli, P. (1983). Bretón de los Herreros e la sua «formula comica». Ímola: Galeati.

Garrido Gallardo, M. Á. (1998). «Marcelino Menéndez Pelayo». En Historia de la literatura española. Siglo XIX (II), V. García de la Concha (dir.) y L. Romero Tobar (coord.), t. 9, 872-886. Madrid: Espasa Calpe. 
GIES, D. T. (1975). Agustín Durán. A Biography and Literary Appreciation. Londres: Tamesis Books.

- (1991). «Hacia un catálogo de los dramas de Dionisio Solís (1774-1834)». En The Eighteenth Century in Spain. Essays in honour of I. L. McClelland. Bulletin of Hispanic Studies 68, 197-210.

- (1993). «Dionisio Solís, entre dos/tres siglos». En EntreSiglos (Roma: Bulzoni) 2, 163-170.

Gil Novales, A. (1992). Diccionario biográfico del Trienio Liberal. Madrid: El Museo Universal.

Gilbert, S. M. y Gubar, S. (1998). La loca del desván (La escritora y la imaginación literaria del siglo XIX). Madrid: Cátedra / Universidad de Valencia / Instituto de la Mujer (Traducción de Carmen Martínez Gimeno).

GÓmez de AVellaneda, G. (1907). Autobiografía y cartas de la ilustre poetisa, hasta ahora inéditas. Huelva (Edición de L. Cruz de Fuentes). [Con el título de Memorias inéditas de la Avellaneda, La Habana: Siglo XX, 1914; con anotaciones de Domingo Figuerola. Como Diálogo de amor, Madrid: Aguilar, 1928; con prólogo y edición de A. Ghiraldo. Como Poesías y epistolario de amor y amistad, Madrid: Castalia / Instituto de la Mujer, con edición de Elena Catena. Autobiografía editada por Nora Catelli en su obra, El espacio autobiográfico (Barcelona: Lumen, 1991).]

Gómez SANTos, M. (1952). Leopoldo Alas, Clarín. Ensayo bio-bibliográfico. Oviedo: Instituto de Estudios Asturianos.

GoNZÁlEZ BLANCo, A. (1917). Los dramaturgos españoles contemporáneos. Valencia: Cervantes.

GoNZÁleZ Ollé, F. (1976). Manual bibliográfico de estudios españoles. Pamplona: EUNSA.

Gual, A. (1960). Mitja vida de teatre. Memóries d'Adrià Gual. Barcelona: AEDOS.

GutiérRez GAMERO, E. (1962). Mis primeros ochenta años. Madrid: Aguilar, 3 vols., 2. ${ }^{a}$ ed.

HaLl, H. B. (1952). «Joaquín Dicenta and the Drama of Social Criticism». Hispanic Review XX, 44-66. 
HERRÁN, F. (1880). Echegaray, su tiempo y su teatro. Madrid: Imprenta Fortanet.

Herrera Navarro, J. (1993). Autores teatrales españoles del XVIII. Madrid: Fundación Universitaria Española.

HORMIGón, J. A. (1996). Autoras en la historia del teatro en España (1500-1994). I: Siglos XVII-XIX. Madrid: Asociación de Directores de Escena.

InIESTA, A. (1958). Don Patricio de la Escosura. Madrid: Fundación Universitaria Española.

Iranzo, C. (1978). Juan Eugenio Hartzenbusch. Boston: Twayne.

- (1980). Antonio García Gutiérrez. Boston: Twayne.

JaCKSON Veyán, José. Vid. AlCÁZAR Simón, M. ${ }^{a}$ A.

Jurado de la Parra, J. (1908). Los del teatro. Semisemblanzas de actrices, autores, críticos, actores, músicos y empresas. Madrid: R. Velasco (Prólogo de Sinesio Delgado).

KIRPATRICK, S. (1989). Las Románticas: Women Writers and Subjectivity in Spain, 1835-1850. Berkley: University of California Press. [Las románticas. Escritoras y subjetividad en España, 1835-1850, Madrid: Cátedra, 1991.]

KIRSCHENBAUM, L. (1944). Enrique Gaspar and the social Drama in Spain. Berkley: University of Carolina Press.

LABANDEIRA, A. (1983). «Adiciones a un diccionario de seudónimos literarios españoles». Dicenda 2, 175-184.

- (1986). «Bibliografía de repertorios básicos para la confección de un catálogo de literatos españoles del siglo XIX». En Homenaje a Pedro Sáinz Rodríguez, 169-203. Madrid: Fundación Universitaria Española.

LARRA, M. J. de (1968). Artículos de crítica literaria y artística. Madrid: Espasa-Calpe (prólogo de J. R. Lomba y Pedraja). [1. ${ }^{a}$ ed., 1923.]

- (1982). Artículos sociales, políticos y de crítica literaria. Madrid: Alhambra (Edición de J. Cano Ballesta).

- (1993). Artículos. Madrid: Cátedra, 12 ed. (Edición de E. Rubio Cremades). 
LÁzARo, Á. (1930). Bibliografía de Jacinto Benavente. Madrid: Compañía Iberoamericana de Publicaciones.

LE GeNTIL, G. (1909). Le poète Manuel Bretón de los Herreros et la societé espagnole de 1830 à 1860. París: Librairie Hachette.

LeSLIE, J. K. (1940). Ventura de la Vega and the Spanish Theatre, 1820-1865. Princeton: Princeton University Press.

LisTA, A. (1844). Ensayos literarios y críticos. Sevilla: Calvo Rubio.

LlORENTE FAlCo, T. (1935). Eduardo Escalante, con motivo de su centenario. Valencia.

LÓPEZ, M. (1979). «Los escritores de la Restauración y las polémicas literarias del siglo XIX en España». Bulletin Hispanique 81 (1.2), 51-74.

LÓPEZ DE FunES, E. (1900). García Gutiérrez. Estudio crítico de su obra dramática. Madrid: Suárez y Cádiz.

LoveTt, G. H. (1977). The Duke of Rivas. Boston: Twayne.

Lozano GuIRAO, P. (1958 y 1959). «El archivo epistolar de don Ventura de la Vega». Revista de Literatura 13, 121-172 y 14, 170-197.

- (1965). Vida y obra de Ricardo de la Vega. Murcia: Imprenta Nogués.

MARRAST, R. (1989). José de Espronceda y su tiempo. Literatura, sociedad y política en tiempos del Romanticismo. Barcelona: Crítica. $\left[1 .^{\mathrm{a}}\right.$ ed. francesa, 1974.]

MARTín, F. (1958). The Dramatic Works of Gaspar de Zavala y Zamo$r a$. University of North Caroline (Tesis de doctorado inédita).

MARTIN, G. C. (1974). Revisión crítica de la biografía de Larra: Nuevos documentos. Ann Arbor: University Microfilms International.

- (1977). «Larra y sus escritos sobre teatro». Cuadernos Hispanoamericanos 320-321, 488-492. [Reseña del libro de J. Monleón, Larra, escritos sobre teatro.]

MARTÍN FERnÁNDEZ, M. ${ }^{\mathrm{a}}$ I. (1981). Lenguaje dramático y lenguaje retórico (Echegaray, Cano, Sellés y Dicenta)). Cáceres: Universidad de Extremadura.

MARTÍn LARRAURI, E. (1979). «Un dramaturgo romántico olvidado: Francisco de Paula Martín». Letterature 2, 95-110. 
MARTínez Olmedilla, A. (1949). José Echegaray (El madrileño tres veces famoso): su vida, su obra, su ambiente. Madrid: Edición del Autor.

MAS FerRer, J. (1978). Vida, teatro y mito de Joaquín Dicenta. Alicante: Instituto de Estudios Alicantinos.

MAYBERri, N. y R. (1988). Francisco Martínez de la Rosa. Boston: Twayne.

MAYORAL, M. (1989). «Las románticas». Ínsula 516, 9-10.

MAYORAL, M., ed. (1990). Escritoras románticas españolas. Madrid: Fundación Banco Exterior.

Mellado, F. de P. (1852 y ss.). Enciclopedia Moderna. Dicccionario Universal de Literatura, Ciencias, Artes, Arquitectura, Industria y Comercio. Madrid.

Menarini, P. (1980). «Larra y Moratín: el teatro español en los comienzos del Romanticismo». En Coloquio Internacional sobre Leandro Fernández de Moratín, 3-13. Abano Terme: Piovan Ed.

MENARINI, P. et alii (1982). El teatro romántico español (1830-1850). Autores, obras, bibliografía. Bolonia: Atesa.

MENÉNDEZ OnRUBIA, C. (1983). Introducción al teatro de Galdós. Madrid: CSIC.

- (1984). El dramaturgo y los actores. Epistolario de Benito Pérez Galdós, María Guerrero y Fernando Díaz de Mendoza. Madrid: CSIC.

Mesonero Romanos, R. (1852-1958). «Catálogo cronológico de los Autores Dramáticos, y alfabético de las Comedias de cada uno. Parte Primera: Desde Lope de Vega a Calderón (1588-1635)». En Dramáticos contemporáneos de Lope de Vega, II, XLV-LV. Madrid: BAE (n. $\left.{ }^{\circ} \mathrm{XLV}\right)$. Y «Parte Segunda: Desde Calderón a Cañizares (1635-1740)», I, XXXVII-LIII. Madrid: BAE (n. ${ }^{\circ}$ XLVII).

- (1880) Memorias de un setentón, natural y vecino de Madrid, escritas por.. Madrid: Oficinas de La Ilustración Española y Americana. [Las memorias se editaron, por entregas, en La llustración Española y Americana, en 1878-79. Una nueva edición, con adiciones y notas, apareció en la misma editorial, en 1881, en dos volúmenes, con un «Apéndice» del marqués de Valmar. Posteriormente se han hecho otras ediciones: Madrid: Renacimiento, 1926; 
Madrid, 1948 y 1955; Madrid: Ed. Mediterránea, 1948; Madrid: Vindel, 1950; Madrid: Librería Iberoamericana, 1955; Madrid: Publicaciones Españolas, 1961, 2 vols.; con edición y estudio de Carlos Seco Serrano, se incluyeron en la B.A.E., en el tomo V de las Obras Completas de don Ramón Mesonero Romanos (Madrid: Atlas, 1967) y Las memorias de un setentón (Madrid: Giner, 1955, con prólogo de Enrique Pastor. Otras ediciones en Madrid: Ábaco, 1982 y Madrid: Castalia / Comunidad de Madrid, 1994 (Edición de José Escobar y Joaquín Álvarez Barrientos).]

- (1881). «Los autores dramáticos de 1836 a 1843». La Ilustración Española y Americana XXXIX (15 de noviembre), 151.

MigUEL DE VAL, M. (1906). Los novelistas en el teatro. Tentativas dramáticas de Doña Emilia Pardo Bazán. Madrid: Imprenta y Lit. de Bernardo Rodríguez.

Molins, A. E. de (1972). Diccionario biográfico y bibliográfico de escritores y artistas catalanes del siglo XIX. Hildesheim: G. Olms (Reedición, Varios tomos). [1. ${ }^{\circ}$ ed., Barcelona: Imprenta F. Giró.]

Monleón, J. (1976). Larra, escritos sobre teatro. Madrid: Cuadernos para el Diálogo.

Montero Alonso, J. (1951). Ventura de la Vega. Su vida y su tiempo. Madrid: Editora Nacional.

Muro, M. Á. (1991). El teatro breve de Bretón de los Herreros. Logroño: Instituto de Estudios Riojanos.

Muro, M. Á., ed. (1998). Bretón de los Herreros: 200 años de escenarios. Logroño: Instituto de Estudios Riojanos.

Navas Ruiz, R. (1979). Imágenes liberales. Rivas-Larra-Galdós. Salamanca: Almar.

NomBela, J. (1976 ). Impresiones y recuerdos. Madrid: Giner (Tebas), 1976.

OCHOA Y RoANnA, E. (1840). Apuntes para una biblioteca de escritores contemporáneos. París: Baudry, varios vols.

OJEDA EsCUdERo, P. (1990). Ventura García Escobar (1817-1859). Biografia y obra dramática. Valladolid: Editora Provincial.

Ossorio Y BERNARD, M. (1903-1904). Ensayo de un catálogo de periodistas españoles del siglo XIX. Madrid: Imprenta J. Palacios. 
OviLo y Otero, M. (1859). Manual de biografía y bibliografía de los escritores españoles del siglo XIX. París: Librería de Rosa y Bouret, 2 vols. [Edición facsímil en Hildesheim: G. Olms, 1976.]

Paco, M. de (1974). María del Carmen de Feliú y Codina. Murcia: Nogués.

- (1993). «Vicente Medina en el teatro de fin de siglo». En Literatura de Levante, F. J. Díez de Revenga y M. de Paco (eds.), 123129. Murcia: Fundación Cultural Caja de Ahorros del Mediterráneo.

Pando Fernández de Pinedo, M. Memorias del reinado de Isabel II. Madrid: B.A.E, n. ${ }^{\circ} 174$.

PASCUAL, P. (1994). Escritores y editores en la Restauración canovista (1875-1923). 2 vols.

Penas VARela, E. (1992). Macías y Larra. Tratamiento de un tema en el drama y en la novela. Santiago de Compostela: Universidad.

Peñuelas, M. (1969). Jacinto Benavente. Boston: Twayne.

Pérez Carrera, J. M. (1991). Andrenio. Gómez de Baquero y la crítica literaria de su época. Madrid: Universidad Complutense (Tesis de doctorado).

PÉrez Galdós, Benito (1920). Memorias de un desmemoriado. Madrid: Alhambra. [Aparecidas como artículos en la revista $\mathbf{L a}$ Esfera. Otras ediciones: en Obras inéditas (Madrid: Renacimiento, 1930, vol. 10; en Obras Completas (Madrid: Aguilar, 1973, vol. 3, págs. 1430-1473; y como Recuerdos y memorias, Madrid: Giner, 1975; con prólogo de Fausto Vicente Gella.]

PORPETTA, A. (1986). Escritores y artistas españoles (Historia de una Asociación centenaria). Madrid: Asociación de Escritores y Artistas Españoles.

PoYÁn, D. (1957). Enrique Gaspar. Medio siglo de teatro español. Madrid: Gredos, 2 vols.

Prellezo, J. M. (1976). Francisco Giner de los Ríos y la Institución Libre de Enseñanza. Bibliografía (1876-1976). Roma: Quaderni di Orientamenti Pedagogici.

RANDOLPH, D. A. (1966). Eugenio de Ochoa y el Romanticismo español. Berkeley / Los Angeles, California: University of California Press. 
- (1972). Don Manuel Cañete, cronista literario del Romanticismo y del post-romanticismo en España. Chapell Hill: University of North Carolina Press.

REES, M. A. (1977). French Authors in Spain, 1800-1850. A Checklist. Londres: Grant \& Cutler.

Rincón Martínez, M. ${ }^{a}$ del C. (1987). «Juan de Tasis y el teatro del siglo XIX». Cuadernos de Investigación de la Literatura Hispánica 8, 123-130.

Roca DE Togores, M. (Marqués de Molins), ed. (1881-1882). Manuel Bretón de los Herreros. Madrid: Autores Dramáticos Contemporáneos, 2 vols.

- (1883). Bretón de los Herreros. Recuerdos de su vida y de su obra. Madrid: Imprenta de M. Tello.

RODERGAS, J. (1951). Els pseudònims usats a Catalunya (Recull de 3.000). Barcelona: Millà.

Rodríguez MoÑino, A. (1955). Don Bartolomé José Gallardo (17761852). Estudio biográfico. Madrid: Sancha.

RoDRf́GUEZ SÁNCHEZ, T. (1994). Catálogo de dramaturgos españoles del XIX. Madrid: Fundación Universitaria Española.

Rogers, P. P. y LAPUENTE, F. A. (1977). Diccionario de seudónimos literarios españoles. Madrid: Gredos.

Romero ToBar, L. (1990). «Los álbumes de las románticas». En Escritoras románticas españolas, M. Mayoral (ed.), 73-93. Madrid: Fundación Banco Exterior.

RuBio CREMADES, E. (1982). «Larra, crítico teatral». Anales de la Universidad de Alicante. Historia Contemporánea 1, 113-126.

RUIz GUERRERO, C. (1996). «El siglo XIX. Un millar de románticas y realistas». En su obra, Panorama de escritoras españolas, II, 61128. Cádiz: Universidad.

SACKETT, T. A. (1982). Galdós y las máscaras. Historia teatral y bibliografía anotada. Verona: Facoltà di Economia e Commercio.

San Martín, A. (1870). Confidencias de Arderíus. Historia de un bufo, referida por... Madrid: Imprenta Española. 
SÁnchez Esteban, I. (1934). Mariano José de Larra (Fígaro). Ensayo biográfico redactado en presencia de numerosos antecedentes desconocidos y acompañado de un catálogo completo de sus obras. Madrid: Hernando.

- (1954). Jacinto Benavente y su teatro (estudio biográfico y crítico). Barcelona: Ariel.

SANCho GIL, F. (1886). Elogio de don Manuel Bretón de los Herreros. Zaragoza: Tipografía La Derecha.

SARRAILH, J. (1936). Un homme d'état espagnol: Martínez de la Rosa. Burdeos / París: École des Hautes Études Hispaniques.

SCARI, R. M. (1972). «El teatro como profesión en las reseñas de Larra». La Torre 75-76, 166-172.

- (1991). «El teatro y la moral en el pensamiento de Larra». Cuadernos Americanos 178, 160-165. [Sobre los artículos de crítica teatral (1833-1835).]

SCHINASI, M. (1982). «Cuatro cartas inéditas de Ventura de la Vega». Revista de Literatura 44, 183-191.

Seminario de Biblografía Hispánica de la Facultad De Filosofía Y LETRAS DE MADRID (1968-1975). Veinticuatro diarios (Madrid, 1830-1900). Artículos y noticias de escritores españoles del siglo $X I X$. Madrid: CSIC, 4 vols.

SERRANO Y SANZ, M. (1903-1905). Apuntes para una biblioteca de escritoras españolas desde el año 1401 al 1833. Madrid: Suc. de Rivadeneyra, 2 vols.

SHERMAN, A. F. Jr. (1993). Mariano José de Larra: A Directory of Historical Personages and Literary Figures in his Writings (with Computerized Indices). Ann Arbor: University Microfilms International.

Simón Díaz, J. (v. a.). Bibliografía de la Literatura Hispánica. Madrid: C.S.I.C., varios vols.

- (1980). Manual de bibliografía de la literatura española. Madrid: Gredos.

Simón Palmer, M. ${ }^{a}$ C. (1983). «Escritoras españolas del siglo XIX». En Censo de escritores al servicio de los Austrias y otros estudios bibliográficos, 99-119. Madrid: CSIC. 
- (1989a). «Las románticas y la sociedad de su tiempo». Ínsula 516, 19-20.

- (1989b). «Mil escritoras españolas del siglo XIX». En Crítica y ficción literaria. Mujeres españolas contemporáneas, VV. AA., 39-59. Granada: Universidad.

- (1989c). «La ocultación de la propia personalidad en las escritoras del siglo XIX». En Actas del IX Congreso de la Asociación Internacional de Hispanistas, S. Neumeister (ed.), I, 91-99. Frankfurt am Main: Vervuet.

- (1990a). «Panorama general de las escritoras románticas españolas». En Escritoras románticas españolas, M. Mayoral (ed.), 9-16. Madrid: Fundación Banco Exterior.

- (1990b). «Introducción» a la edición de Rosario de Acuña, Rienzi el Tribuno. El padre Juan, 7-38. Madrid: Castalia / Instituto de la Mujer.

- (1991). Escritoras españolas del siglo XIX. Manual bio-bibliográfico. Madrid: Castalia.

SisCARS, N. (1906). Tamayo. Estudio crítico-biográfico. Barcelona: Tipografía Católica.

SMITH, P. (1972). «Blasco Ibáñez and Drama». Hispanófila (Urbana) $46,35-40$.

SMITH, W. F. (1942). «Contributions of Rodríguez Rubí to the Development of the Alta Comedia». Hispanic Review X, 53-63.

- (1948). «Rodríguez Rubí and the Dramatic Reforms of 1849». Hispanic Review XVI, 311-320.

Sobejano, G. (1972). «Echegaray, Galdós y el melodrama». Anales Galdosianos (anejo), 94-115.

- (1982). «Echegaray: temas y modos». En Historia y crítica de la literatura española. Romanticismo y Realismo, F. Rico (ed.), V, 656-662. Barcelona: Crítica.

Sociedad DE AUTORes Españoles (1913). Catálogo General. Año 1913. Madrid: Velasco Impresor.

Stoudemire, S. A. (1930). The Dramatic Works of Gil y Zárate. Chapel Hill: North Carolina University Press. 
UNA BIBLIOGRAFÍ (SELECTA) PARA LA RECONSTRUCCIÓN DE LA VIDA ESCÉNICA...

Teicmann, R. (1986). Larra: sátira y ritual mágico. Madrid: Playor. [Un análisis antroplógico y psicoanalítico.]

- (1989). The Autor Catalogues of the Biblioteca Nacional. Vol. 1: Catálogo general de libros impresos, hasta 1981; vol. 2: Catálogo general de libros impresos, 1982-1987. Cambridge: Chadwyck-Healey.

UMBRAL, F. (1965). Larra. Anatomía de un dandy. Madrid: Alfaguara.

VAlis, N. V. (1991). «Dos poesías de Almanaque, por Leopoldo Alas». Anales de Literatura Española de la Universidad de Alicante 7, 195-205. [Referencias sobre autores y obras teatrales del momento.]

VAllejo, I. y OJEDA, P. (1994). José Zorrilla. Bibliografía con motivo de un centenario (1893-1993). Valladolid: Ayuntamiento.

VARELA, J. L. (1948). Vida y obra literaria de Gregorio Romero Larrañaga. Madrid: CSIC.

- (1983). Larra y España. Madrid: Espasa-Calpe.

VV.AA. (1981-1984). Autores dramáticos contemporáneos y joyas del teatro español del siglo XIX. Madrid: Imprenta Fortanet, 2 vols.

ViCo, A. (s.a.). Mis memorias. Madrid: Serrano.

Vilches Díaz, A. (1986). Autores y anónimos españoles en los Índices inquisitoriales. Madrid: Universidad Complutense.

WHITAKER, D. S. (1992). «La mujer ilustrada como dramaturga: el teatro de María Rosa Gálvez». En Actas del X Congreso de la Asociación Internacional de Hispanistas, A. Vilanova (ed.), II, 1.5511.559. Barcelona: PPU.

ZABATSKY, D. S. (1982). «An Annoted Bibliography of NineteenhCentury Catalan, Galician and Spanish Author Bibliographies». Hispania (California) LXV (2), 212-224.

ZAMACoIS, E. (1910). «Los novelistas en el teatro». La Ilustración Española y Americana 15 (22 de abril).

ZorRILlA, J. (1880). Recuerdos del tiempo viejo. Barcelona: Imprenta de los Sucesores de Ramírez, 3 vols. [Publicadas en El Lunes del Imparcial, en 1879-80. Otras ediciones: Madrid, 1880, 2..$^{\mathrm{a}}$ ed. aumentada, 2 vols.; Madrid: Gutenberg, 1882, 3 vols.; en Obras 
completas (Valladolid: Santarén, 1943, vol. II, págs. 1.729-2.097, con edición de Narciso Alonso Cortés); Madrid: Publicaciones Españolas, 1961, 2 vols., con prólogo de José Luis Martín; Madrid: Rodríguez Muñoz, 1963.]

\section{SOBRE OBRAS DRAMÁTICAS ${ }^{10}$}

Aguilar Piñal, F. (1972). «Noticia del Índice de Comedias de Manuel Casal y Aguado». Cuadernos Bibliográficos 28, 153-162.

Agulló y Coвo, M. (1995). La colección de teatro de la Biblioteca Municipal de Madrid. Madrid: Ayuntamiento. [Recoge los trabajos: «La colección de teatro de la Biblioteca Municipal de Madrid». Revista de Literatura 71/72 (1969), 169-213; 73/74 (1970), 233-274; y 75/76 (1970), 189-252. Y Revista de la Biblioteca, Archivo y Museo del Ayuntamiento de Madrid 3 (1977), 177-231; 4 (1978), 125-187; 5 (1979), 193-218; 6 (1979), $131-190 ; 7 / 8$ (1980), 223-302; 9/10 (1981), 103-183; y 11/12 (1982), 259-351.]

ARTEAGA, J. de ([1839]). Índice alfabético de comedias, tragedias y demás piezas del teatro español. Manuscrito 14.698 de la Biblioteca Nacional de Madrid.

ARTigas, M. (1930). Catálogo de los manuscritos de la Biblioteca Menéndez Pelayo. Santander: J. Martínez.

AyAlA, M. ${ }^{a}$ Á. (1993). Las colecciones costumbristas (1870-1885). Alicante: Universidad.

BARRERA y LeIRADo, C. A. de la (1860). Catálogo bibliográfico del Teatro antiguo español, desde sus orígenes hasta mediados del siglo XVIII. Madrid: Rivadeneyra. [Ediciones facsimilares en Londres: Tamesis Books, 1968 y Madrid: Gredos, 1969.]

Bellamy-KLEMME (1956). Colección de comedias españolas de los siglos XIX y XX. Boulder: University of Colorado.

10 Tampoco puedo consignar en esta bibliografía, por razones de espacio, una completa nómina de ediciones y estudios de piezas dramáticas de la época. 
UNA BIBLIOGRAFÍ (SELECTA) PARA LA RECONSTRUCCIÓN DE LA VIDA ESCÉNICA...

Cambronero, C. (1902). Catálogo de la Biblioteca Municipal de Madrid. Madrid: Imprenta Municipal.

Catálogo colectivo del patrimonio bibliográfico español. Siglo XIX. Madrid: Dirección General del Libro y Bibliotecas-Arco / Libros.

Catálogo de comedias antiguas y modernas, tragedias, autos sacramentales, piezas en un acto, unipersonales, sainetes y entremeses... que se hallan a la venta en la librería de Cuesta.

(s. a.). Catálogo de las comedias y piezas en un acto, autos sacramentales, monólogos, unipersonales, sainetes y entremeses que se hallan a la venta en su depósito, Plazuela de la Cebada, $n .^{\circ} 96$. Madrid: Imprenta S. M. Marés.

(s. a.). Catálogo de piezas dramáticas publicadas en España durante el siglo XVIII, y autores que las escribieron. Manuscrito 6.146 de la Biblioteca Nacional de Madrid.

(1990). Catálogo colectivo del patrimonio Bibliográfico Español: Siglo XVII / Biblioteca Nacional. Madrid: Ministerio de Cultura / Arco Libros. [Contiene I, A.]

(s. a). Catálogo fotocopiado de Títulos-Materias de la Biblioteca Nacional. Madrid: Biblioteca Nacional, vols. 1-11.

(1913). Catálogo general. Año 1913. Madrid: Sociedad General de Autores Españoles.

COE, A. M. (1935). Catálogo bibliográfico y crítico de las comedias anunciadas en los periódicos de Madrid desde 1661 hasta 1819. Baltimore: The Johns Hopkins University Press / London: Oxford University Press / París: Belles Lettres.

(1789-90-91). Colección de las mejores comedias nuevas que se van a representar en los teatros de esta corte. Madrid: Imprenta Manuel González, 3 vols.

(s. a). Colección de sainetes sueltos, siglos XVIII y XIX. Valencia / Madrid: Varias Imprentas.

COTARElo y MORI, E. (1911). Colección de entremeses, loas, bailes, jácaras y mojigangas desde fines del siglo XVI a mediados del XVIII. Madrid: Bailly-Bailliére, 2 vols.

- (1928). «Editores y galerías de obras dramáticas en Madrid en el siglo XIX». Revista de Archivos, Bibliotecas y Museos (Madrid) 18, 121-139. 
- (1930). Teatro español. Catálogo abreviado de una colección dramática española, hasta fines del siglo XIX, y de obras relativas al teatro español. Madrid: V. e H. de J. Ratés.

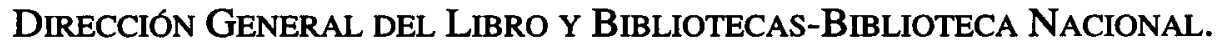
Catálogo colectivo del patrimonio bibliográfico español: Impresos del siglo XIX. Madrid: Arco/Libros, 4 vols.: I (A-Alm), II (AloArb), III (Arc-Az), IV (Índices), hasta el momento. [La obra constará de 30 vols. aproximadamente. Recoge los ejemplares localizados en las bibliotecas españolas.]

ESQUER TORRES, R. (1969). La colección dramática «El teatro moderno». Madrid: CSIC.

FAJARDO Y MONROY, J. I. (1717). Títulos de todas las comedias que en verso español y portugués se han impreso hasta el año de 1716. Manuscrito de la Biblioteca Nacional de Madrid.

FERnÁNDEZ DE MORATÍn, L. (1850). «Catálogo de piezas dramáticas publicadas en España desde principios del siglo XVIII hasta la época presente (1825)». En Obras de D. Nicolás y D. Leandro Fernández de Moratín, 327-334. Madrid: Rivadeneyra $\left(B A E\right.$, n. $^{\circ}$ 2).

FonTANella, L. (1982). La imprenta y las letras en la España romántica. Berna / Frankfurt: Lang.

FREIRE LÓPEZ, A. (1983). Índice bibliográfico de la colección documental del Fraile. Madrid: Servicio Histórico Militar.

FundaCIÓN JUAN MARCH (1986). Catálogo de obras de teatro español del siglo XIX. Madrid: Fundación Juan March.

GARCÍA DE la HuERTA, V. (1785). Catálogo general de comedias, tragedias, autos, zarzuelas, entremeses y otras obras correspondientes al Theatro Hespañol. Madrid: Imprenta Real.

Goenaga, A. y Maguna, J. P. (1971). Teatro español del siglo XIX. Análisis de obras. Nueva York: Las Américas.

González herrán, J. M. y Penas Varela, E. (1992). Cronología de la literatura española. T. 3. Siglos XVIII y XIX. Madrid: Cátedra.

GregG, K. C. (1987). An Index to the "Teatro Español» in the Biblioteca de Palacio. Charlottesville, VA: Biblioteca Siglo de Oro (n. $\left.{ }^{\circ} 7\right)$. 
Gutiérrez Iglesias, F. y SÁez Picazo, F. ((1980). Catálogo de los Manuscritos de la sección de Fondos Modernos de la Biblioteca Menéndez Pelayo. Santander: Diputación Provincial.

KINGS, A. M. (1965). Catalogue of comedias sueltas. University of North Carolina, Library Studies, $n .^{\circ} 4$.

La BARRERA Y LeIRADO, C. A. de (1969). Catálogo bibliográfico y biográfico del teatro antiguo español desde sus orígenes hasta mediados del siglo XVIII. Madrid: Gredos (facsímil).

Lalama, V. de (1867). Índice general, por orden alfabéticvo, de cuantas obras dramáticas y líricas han sido aprobadas por la Junta de Censura y censores de oficio, para todos los teatros del reino y de Ultramar (1850-1866). Madrid: Imprenta de G. Alhambra.

MARTínez, R., ed. (1990). Teatro inédito gaditano del siglo XIX. Madrid: Sílex.

Medel Del CASTILlo (1735). Índice general alfabético de todos los títulos de comedias que se han escrito por varios autores, antiguos y modernos, y los autos sacramentales, y alegóricos, assí de don Pedro Calderón de la Barca como de otros autores clásicos... Madrid: Imprenta de Alfonso de Mora.

MENARINI, P. et alii (1982). El teatro romántico español (1830-1850). Autores, obras, bibliografía. Bolonia: Atesa.

Mesonero Romanos, R. de. Índice alfabético de las comedias, tragedias, autos y zarzuelas del teatro antiguo español, desde Lope de Vega a Cañizares. Madrid: Biblioteca de Autores Españoles, t. XLIX.

Moll, J. (v. a.). «Catálogo de comedias sueltas conservadas en la Biblioteca de la Real Academia Española». Boletín de la Real Academia Española XLIV (1964), 113-168, 309-360, 541-556; XLV (1965), 203-235; XLVI (1966), 125-158.

Montaner, J. (1951). La colección teatral de don Arturo Sedó. Barcelona.

Moratín, L. F. de (1944). «Catálogo de piezas dramáticas...». En Obras de D. Nicolás y D. Leandro Fernández de Moratín, 327-334. Madrid: Atlas (BAE, II). 
Moreno Garbayo, N. (1957). Catálogo de documentos referentes a diversiones públicas, conservados en el Archivo Histórico Nacional. Madrid.

NIPHO, M. (1805). Colección de los mejores papeles poéticos y composiciones dramáticas. Madrid: Cano, 2 vols.

OVILo y OTERo, M. (s. a.). Catálogo biográfico-bibliográfico del teatro moderno español desde el año de 1750 hasta nuestros días. Manuscrito de la Biblioteca Nacional de Madrid, n. ${ }^{\circ} 14.617$.

PALAU y DUlCET, A. (1948-1977). Manual del librero. Barcelona: Ed. Antonio Palau / Londres: Dolphin, vols. 1-28. [Índices (19811987), vols. 1-7.]

PAZ, J. (1934-1935). Catálogo de las piezas de teatro que se conservan en el Departamento de Manuscritos de la Biblioteca Nacional. Madrid: Blass, 2. ${ }^{\mathrm{a}}$ ed., 2 vols.

Rogers, P. P. (1934). «Dramatic Copyright in Spain before 1850». The Romanic Review 25, 35-39.

- (1940). The Spanish Drama. Collection in the Oberling College Library. A descriptive Catalogue. Oberling Coll. P. C.

ROMERo TOBAR, L. (1988). «La Colección General de Comedias de Ortega (Madrid, 1826-1834)». En Varia Bibliographica. Homenaje a Simón Díaz, VV. AA., 599-609. Kassel: Reichenberger.

SÁNCHEZ MARIANA, M. (1986). «Documentos para la historia del teatro español en la sección de Manuscritos de la Biblioteca Nacional». En Homenaje a Luis Morales Oliver, 123-135. Madrid: Fundación Universitaria Española.

- (1989). «Repertorios manuscritos de obras dramáticas conservados en la Biblioteca Nacional». En Estudios sobre Calderón y el Teatro de la Edad de Oro. Homenaje a Kurt y Roswitha Reichenberger, 233-258. Barcelona: PPU.

SERÍs, H. (1948-1954). Manual de bibliografía de la literatura española. Syracuse, N. York: Syracuse University.

Simón PAlmer, M. ${ }^{\text {a }}$ C. (1979). Catálogo de manuscritos de los siglos XVIII-XX de la Biblioteca del Instituto del Teatro de Barcelona. Madrid: CSIC (Cuadernos Bibliográficos, 39).

Sullivan, H. y Bershas, H. (1984). The Wayne State University Collection of Comedias Sueltas. Detroit: Wayne State U. P. 


\section{GÉNEROS TEATRALES}

\section{V.1. Teoría}

GaRCía CASTAÑEDA, S. (1971). Las ideas literarias en España. Berkeley: University of California Press.

GARCíA LoRENZO, L. (1967). «La denominación de los géneros teatrales en España durante el siglo XIX y el primer tercio del siglo XX». Segismundo 5-6, 191-199.

MatTauCH, H. (1990). «Algunas denominaciones nuevas de los géneros literarios». Revista de Literatura 104, 519-525. [Completa el trabajo de García Lorenzo.]

ROMERO TOBAR, L. (1970). La teoría dramática española (18001870). Madrid: Facultad de Filosofía y Letras de la Universidad Complutense. [Resumen de la tesis de doctorado.]

- (1994). «Géneros y espectáculos preexistentes. 1. Teatro y espectáculos musicales. 2. Tragedias. 3. El teatro antiguo español. 4. Teatro sentimental y de espectáculo. 5. La comedia. 6. El teatro menor y la parodia. 6. Las fiestas públicas y otras diversiones». En su obra, Panorama crítico del Romanticismo español. Madrid: Castalia.

\section{V.2. Tipologías}

\section{V.2.1. Drama}

ABELláN, J. L. (1984). Historia del pensamiento español. IV: Liberalismo y Romanticismo (1808-1868), capítulo 11. Madrid: Espasa Calpe.

Alonso CorTés, N. (1941-42). «Sobre el drama romántico». Castilla I, 103-114.

CALDERA, E. (1974). Il dramma romantico in Spagna. Pisa: Università / Giardini. 
- (1991). «Il teatro del pathos e dell'orrore al principio del Ottocento: fedeltà ai canoni del classicismo e presentimenti romantici». EntreSiglos (Roma) 1, 55-74.

- (1992). «Horror y pathos en los dramones de principios del siglo XIX». En Actas del X Congreso de la Asociación Internacional de Hispanistas, A. Vilanova (ed.), 1.220-1.228. Barcelona: PPU.

CRespo MATEllán, S. (1979). La parodia dramática en la literatura española (Esbozo de una historia de la parodia dramática en la literatura española...). Salamanca: Universidad.

FreIRE LÓPEZ, A. M. a (1995). «El teatro se ríe de sí mismo: las parodias de los dramas románticos». Romanticismo (Génova) 5, 113-115.

GIES, D. T. (1984). «Juan de Grimaldi y la máscara romántica». Romanticismo 2, 133-141.

- (1989). «Entre drama y ópera: la lucha por el público teatral en la época de Fernando VII». Bulletin Hispanique 91, 37-60.

- (1991). «Hacia un catálogo de los dramas de Dionisio Solís (17741834)». En The Eighteenth Century in Spain. Essays in honour of I. L. McClelland. Bulletin of Hispanic Studies 68, 197-210.

MARRAST, R. (1978). «Le drame en Espagne à l'époque romantique, de 1834 à 1844: contribution à son approche sociologique». En Romanticisme, Réalisme, Naturalisme en Espagne et en Amérique Latine, VV. AA., 35-45. Lille: Université.

Morley, S. G. (1948). «The Curious Phenomenon of Spanish Verse Drame». Bulletin Hispanique 50, 445-462.

NAVAs RuIz, R. (1979). «El drama romántico: héroes y víctimas». En Imágenes liberales. Rivas. Larra. Galdós, 136-188. Salamanca: Almar.

PICOCHE, J.-L. (1978). «Existe-t-il un drame romantique espagnol?». En Romanticisme, Réalisme, Naturalisme en Espagne et en Amérique Latine, VV. AA., 47-55. Lille: Université.

- (1982). «Los militares y el ejército en el drama romántico». Romanticismo 1, 35-44.

REAL RAMOS, C. (1983). «De los "desarreglados monstruos" a la estética del fracaso (Prehistoria del drama romántico)». Anales de Literatura Española de la Universidad de Alicante 2, 419-445. 
Rogers, P. P. (1929). «The Peninsular War as a Source of Inspiration in the Spanish Drama of 1808-1814». Philological Quarterly VIII, 264-269.

- (1930). «The Drama of Pre-Romantic Spain». The Romanic Review XXI, 315-324.

Romero Tobar, L. (1994). «Los dramas románticos». En su obra, Panorama crítico del Romanticismo español. Madrid: Castalia.

Ruiz RAMÓN, F. (1988). «Imágenes del drama romántico: Ideología y símbolo». En Resonancias románticas. Evocaciones del romanticismo hispánico, VV. AA., 181-194. Madrid: Porrúa.

SÁNCHEZ, R. G. (1976). «Between Macías and Don Juan: Spanish Romantic Drama and the Mythology of Love». Hispanic Review XLIV, 27-44.

SEbold, R. P. (1986). «Nuevos Cristos en el drama romántico español». Cuadernos Hispanoamericanos 431, 126-132.

SHAw, D. L. (1997). «El teatro (II): El drama romántico como modelo literario e ideológico». En Historia de la literatura española. Siglo $X I X(I)$, V. García de la Concha (ed.) y G. Carnero (coord.), t. 8, 314-351. Madrid: Espasa Calpe.

SMITH, P. (1972). «Blasco Ibáñez and Drama». Hispanófila (Urbana) $46,35-40$.

a) Drama histórico

CAlDERA, E. (1993). «De la tragedia neoclásica al drama histórico romántico: por qué y cómo». En Entre Siglos 2, E. Caldera y R. Froldi (eds.), 67-74. Roma: Bulzoni.

García CASTAÑEdA, S. (1983). «Los hermanos Asquerino o el uso y mal uso del drama histórico». En Teatro romantico spagnolo, VV. AA., 23-42. Bologna: Patron.

GARELLI, P. (1984). «Conquista, conquistatori e conquistati sulla scene romantica spagnola». Quaderni de Filologia e Lingue Romanze (Macerata) 4, 43-64.

GONZÁlEZ DE GARAY, M. ${ }^{\mathrm{a}}$ T. (1983). «De la tragedia al drama histórico: dos textos de Martínez de la Rosa». Cuadernos de Investigación 
Filológica (Logroño) 9, 199-234. [Analiza La viuda de Padilla y La conjuración de Venecia.]

MARTíneZ DE LA RosA, F. (1962). «Apuntes sobre el drama histórico» y «Apéndice sobre la tragedia española». En Obras, vol. I (289-291) y III (91-173). Madrid: Atlas (Edición de C. Seco Serrano).

MARTíneZ TORRÓN, D. (1993). El alba del Romanticismo español (con inéditos reopilados de Lista, Quintana y Gallego). Sevilla: Alfar. [Estudia la evolución del drama histórico en España hasta 1825.]

ROMERO TOBAR, L. (1994). «Marcas del drama histórico». En su obra, Panorama crítico del Romanticismo español, 310-322. Madrid: Castalia.

SAN Vicente, F. (1997). «El teatro (II): Continuidad del drama histórico». En Historia de la literatura española. Siglo XIX (I), V. García de la Concha (ed.) y G. Carnero (coord.), t. 8, 384-399. Madrid: Espasa Calpe.

SARRAILH, J. (1936). «L'histoire et le drama romantique (A propos d'Alfonso el Casto d'Hartzenbusch)». Bulletin Hispanique 38, 19-40.

SCHURLKNIGHT, D. (1983). «El historicismo de Larra y la aristocracia del talento». Cuadernos Americanos 247, 157-165.

b) Drama rural

CÁCERES SÁNCHEZ, M. (1991). El almeriense Álvarez de Sotomayor (1880-1947) y la literatura rural en España. Almería: Instituto de Estudios Almerienses.

MAINER, J.-C. (1968). «José López Pinillos en sus dramas rurales». Papeles de Son Armadans CL, 229-258 (También en su obra, Literatura y pequeña burguesía, Madrid: Edicusa, 1972).

PACo, M. de (1971-1972). «El drama rural en España». Anales de la Universidad de Murcia. Filosofía y Letras XXX (1-2), 141-170. 


\section{V.2.2. Melodrama}

CALDERA, E. (1992). «Horror y pathos en los "dramones" de principios del siglo XIX». En Actas del X Congreso de la Asociación Internaciopnal de Hispanistas, A. Vilanova (ed.), II, 1221-1228. Barcelona: PPU.

DENGLER GASSIN, R. (1986). «El melodrama francés: su proceso de penetración en España, su proyección y acogida en las tablas madrileñas». Récifs $6,138-160$.

DíEZ TABOADA, J. M. ${ }^{a}$ (1998). «El teatro durante la Restauración y el fin de siglo: El melodrama y el realismo. Echegaray y sus imitadores». En Historia de la literatura española. Siglo XIX (II), V. García de la Concha (ed.) y L. Romero Tobar (coord.), t. 9, 109-118. Madrid: Espasa Calpe.

Escobar, J. y Percival, A. (1984). «De la tragedia al melodrama». Romanticismo (Génova) 2, 141-146.

Rubio JiMÉnEZ, J. (1989). «Melodrama y teatro político en el siglo XIX. El escenario como tribuna política». Castilla 14, 129-149.

Sobejano, G. (1978). «Echegaray, Galdós y el melodrama». Anales Galdosianos (anejo), 94-115.

\section{V.2.3. Comedia}

CAldera, E. (1978). La commedia romantica in Spagna. Pisa: Giardini.

GIES, D. T. (1997). «El teatro (II): El teatro clasicista durante el reinado de Fernando VII y el Romanticismo ("La comedia")». En Historia de la literatura española. Siglo XIX (I), V. García de la Concha (ed.) y G. Carnero (coord.), t. 8, 300-307. Madrid: Espasa Calpe.

MAZADE, Ch. de (1847). «La comédie moderne en Espagne: Bretón de los Herreros, Ventura de la Vega, Rodríguez Rubí». Revue des Deux Mondes XIX, 432-461.

SALVAT, Ricard (1995). «La comedia en el siglo XIX: entre el teatro y el espectáculo». En Actas del I Congreso sobre Historia y Crítica 
del Teatro de Comedias. El siglo XIX: ... Y la burguesía también se divierte. El Puerto de Santa María: Ayuntamiento.

a) «Alta Comedia»

CARNERO, G. (1997). «Introducción a la primera mitad del siglo XIX español». En Historia de la literatura española. Siglo XIX (I), V. García de la Concha (ed.) y G. Carnero (coord.), t. 8, XVII-C [Cf. «El teatro, de Moratín a la "alta comedia"», LI-LIV. Madrid: Espasa Calpe.

DíEz TABOADA, J. M. ${ }^{a}$ (1997). «El teatro (II): La "alta comedia"». En Historia de la literatura española. Siglo XIX (I), V. García de la Concha (ed.) y G. Carnero (coord.), t. 8, 399-408. Madrid: Espasa Calpe.

EZQUERRA LAPETRA, F. (1991). «El adulterio como arquetipo de la alta comedia (1847-1892)». En Arquetipos teatrales y convenciones sociales, J. L. Trullo-Herrera (ed.).

SMITH, W. F. (1942). «Contributions of Rodríguez Rubí to the Development of the Alta Comedia». Hispanic Review X, 53-63.

- (1948). «Rodríguez Rubí and the Dramatic Reforms of 1849». Hispanic Review XVI, 311-320.

b) Comedia sentimental

CAÑAs MURILLO, J. (1994). La comedia sentimental, género español del siglo XVIII. Cáceres: Universidad de Extremadura.

GARCía GARRosa, M. ${ }^{\text {a }}$ J. (1990). La retórica de las lágrimas. La comedia sentimental española (1751-1802). Valladolid: Universidad.

Pataky-Kosove, J. L. (1978). The "comedia lacrimosa» and Spanish Romantic Drama (1773-1865). Londres: Tamesis Books. 
c) Comedia de magia

ÁlvArez BARrientos, J. L. (1988). «Aproximación a la incidencia de los cambios estéticos y sociales de finales del siglo XVIII y principios del XIX en el teatro de la época: comedias de magia y dramas románticos». Castilla 13, 17-33.

- (1990). «Público y creencia en la comedia de magia». En Homenaje a Alberto Navarro, VV. AA. Kassel: Reichenberger.

- (1997). «El teatro (I): Las formas teatrales populares». En Historia de la literatura española. Siglo XIX (I), V. García de la Concha (ed.) y G. Carnero (coord.), t. 8, 275-281. Madrid: Espasa Calpe. [Sobre comedias de magia, especialmente.]

Blasco, J. et alii, eds. (1992). La comedia de magia y de santos (siglos $X V I-X I X)$. Madrid: Júcar.

CALdera, E. (1982). «La última etapa de la comedia de magia». En Actas del séptimo Congreso de la Asociación Internacional de Hispanistas, I, 247-253. Roma: Bulzoni.

- (1983). «La magia nel teatro romantico». En Teatro di magia I, E. Caldera (ed.), 185-205. Roma: Bulzoni.

CAldera, E., ed. (1983). Teatro di magia I. Roma: Bulzoni.

- (1991). Teatro di magia II. Roma: Bulzoni.

CARo BARoja, J. (1974). Teatro popular y de magia. Madrid: Revista de Occidente.

Fuente Ballesteros, R. de la (1991-92). «La "teatralidad" de la comedia de magia». Draco (Univ. de Cádiz), 3-4, 167-189.

GIES, D. T. (1990). «Don Juan Tenorio y la tradición de la comedia de magia». Hispanic Review 58, 1-17.

- (1992). «In re magica veritas: Enrique Zumel y la comedia de magia en la segunda mitad del siglo XIX». En La comedia de magia y de santos (siglos XVI-XIX), J. Blasco et alii (eds.), 433461. Madrid: Júcar.

IZQUIERDO IZQUIERDO, L. (1986). «Comedias de magia en Valencia (1800-1850)». Revista de Literatura 96, 387-405. 
- (1992). «Las comedias de magia y de santos (1800-1850)». En La comedia de magia y de santos (siglos XVI-XIX), J. Blasco et alii (eds.), 411-420. Madrid: Júcar.

Oliva, C. y MAestre, R. (1992). «Espacio y espectáculo en la comedia de magia de mediados del siglo XIX». En La comedia de magia y de santos (siglos XVI-XIX), J. Blasco et alii (eds.), 421-432. Madrid: Júcar.

d) Comedia histórica

CARRIÉRE, M. T. (1981). «El palco de la reina, "comedia histórica" al margen del Romanticismo». Iris (Montpellier) 2, 3-21.

SMITH, W. F. (1950). «The historical Play in the Theatre of Tomás Rodríguez Rubí». Bulletin of Hispanic Studies 27, 221-228.

\section{V.2.4. Tragedia}

Aguilar Piñal, F. (1993). «La tragedia Tarfira (1826) del conde de Cantillana». Boletín de la Real Academia Sevillana de Buenas Letras 21, 57-64.

Cacho Blecua, J. M., ed. (1984). «Ataúlfo, tragedia inédita del duque de Rivas». El Crotalón 1, 393-465.

CAldERA, E. (1993). «De la tragedia neoclásica al drama histórico romántico: por qué y cómo». En Entre Siglos 2 (Roma: Bulzoni), 67-74.

EsCobAR, J. y PeRCIVAL, A. (1984). «De la tragedia al melodrama». Romanticismo (Génova) 2, 141-146.

FERNÁNDEZ CABEZón, R. (1984). «Ataúlfo visto por dos trágicos: Agustín de Moreto y el duque de Rivas». Castilla 8, 95-100.

GIES, D. T. (1997). «El teatro (II): El teatro clasicista durante el reinado de Fernando VII y el Romanticismo ("La tragedia")». En 
Historia de la literatura española. Siglo XIX (I), V. García de la Concha (ed.) y G. Carnero (coord.), t. 8, 307-313. Madrid: Espasa Calpe.

GonZÁlez DE GARAY, M. ${ }^{\mathrm{a}}$ T. (1983). «De la tragedia al drama histórico: dos textos de Martínez de la Rosa». Cuadernos de Investigación Filológica (Logroño) 9, 199-234.

MARTÍNEZ TORRÓN, D. (1989). «Roger de Flor, tragedia inédita e incompleta de Alberto Lista». En Homenaje a Antonio Vilanova, VV. AA., II, 387-411. Barcelona: Universidad.

\section{V.2.5. Teatro político}

BoAl, A. (1974). Teatro del oprimido y otras poéticas políticas. Buenos Aires: Ediciones de la Flor.

CALDERA, E. (1985). «L'Inquisizione e il fanatismo religioso nel teatro spagnolo del primo Ottocento». Letterature 8, 27-42.

CALDERA, E., ed. (1992). Teatro politico spagnolo del primo Ottocento. Roma: Bulzoni.

Calderone, A. (1984). «El lenguaje del liberalismo y del absolutismo en el teatro político». En Romanticismo 2. Atti del III Congresso sul Romanticismo spagnolo e ispanoamericano. Il linguaggio romantico, 38-46. Génova: Facoltá di Magistero.

CARNero, G. (1988). «Un ejemplo de teatro revolucionario en la España napoleónica». España Contemporánea I (2), 49-66.

- (1991). «Temas políticos contemporáneos en el teatro de Gaspar Zavala y Zamora». En Teatro politico spagnolo del primo Ottocento, E. Caldera (ed.), 19-39. Roma: Bulzoni.

Castellón, A. (1994). El teatro como instrumento político en España, 1895-1914. Madrid: Endymión (Prólogo de Ricardo Doménech).

Castillo, A. (1977). «El teatro en la Revolución de Septiembre». Tiempo de Historia 34, 60-71.

DÉROZIER, A. (1975). Escritores políticos españoles (1789-1854). Madrid: Turner. 
FÁBREGAS, X. (1968). Teatro català d'agitaciò politica. Barcelona: Edicions 62.

FREIRE LÓPEZ, A. (1997). «El teatro (II): El teatro político durante el reinado de Fernando VII». En Historia de la literatura española. Siglo XIX (I), V. García de la Concha (ed.) y G. Carnero (coord.), t. 8, 293-300. Madrid: Espasa Calpe.

GIES, D. T. (1988). Theatre and Politics in Nineteenth-Century Spain: Juan de Grimaldi as Impresario and Government Agent. Cambridge: Cambridge University Press.

- (1992). «Hacia un mito anti-napoleónico en el teatro español de los primeros años del siglo XIX». En Teatro politico spagnolo del primo Ottocento, E. Caldera (ed.), 43-62. Roma: Bulzoni.

LAFARGA, F. (1990). «El teatro de la revolución y la revolución en el teatro: el caso de España hasta 1835». En Cultura hispánica y Revolución francesa, VV. AA., 129-146. Roma: Bulzoni.

- (1991). «Teatro político español (1805-1840): ensayo de un catálogo». En Teatro politico spagnolo del primo Ottocento, E. Caldera (ed.), 167-251. Roma: Bulzoni.

LARRAZ, E. (1974). «La satire de Napoleón Bonaparte et Joseph dans le théâtre espagnol: 1808-1814». En Hommage à André JouclaRuau, VV. AA., 126-137. Aix-en-Provence: Université.

- (1979). «Joseph Robrenyo et le premier théâtre catalan politique». En Hommage des hispanistes a Noël Salomon, VV. AA., 475-486. Barcelona: Laia.

- (1987). La Guerre d'Independence espagnole au théâtre. Anthologie. Aix-en-Provence: Université.

- (1988). Théâtre et politique pendant la Guerre d'Independence espagnole: 1808-1814. Aix-en-Provence: Université.

- (1992). «El teatro de propaganda política de Francisco de Paula Martí durante la Guerra de la Independencia y el Trienio Liberal». En Teatro politico spagnolo del primo Ottocento, E. Caldera (ed.), 105-124. Roma: Bulzoni.

RUBIo JiMÉnEZ, J. (1989). «Melodrama y teatro político en el siglo XIX. El escenario como tribuna política». Castilla 14, 129-149.

- (1994). «José Gutiérrez de Alba y los inicios de la revista política en el teatro». Crítica Hispánica (Johnson City) 16.1, 129-140. 
- (1995). «Teatro y política: Las aleluyas vivientes de José María Gutiérrez de Alba». Crítica Hispánica 17.1, 127-141.

- (1997). «El teatro (II): El teatro político durante el reinado de Isabel II y el Sexenio revolucionario». En Historia de la literatura española. Siglo XIX (I), V. García de la Concha (ed.) y G. Carnero (coord.), t. 8, 409-414. Madrid: Espasa Calpe.

RuIz Silva, C. (1985). «Política y guerras civiles en la obra de García Gutiérrez». Cuadernos Hispanoamericanos 415, 91-100.

SERRANO, C. (1983). «Notas sobre el teatro obrero a finales del siglo XIX». En El teatro menor en España a partir del siglo XVI, L. García Lorenzo (ed.), 263-277. Madrid: CSIC.

\section{V.2.6. Teatro menor (satírico, bufo y por horas)}

ÁlVAREZ BARRIENTOS, J. (1998). «Los bufos y otras formas musicales». En Historia de la literatura española. Siglo XIX (II), V. García de la Concha (ed.) y L. Romero Tobar (coord.), t. 9, 170-172. Madrid: Espasa Calpe.

ANDURA VARELA, F. (1992). «Del Madrid teatral del XIX: la llegada de la luz, el teatro por horas, los incendios, los teatros de verano». En Cuatro siglos de teatro en Madrid, Andrés Peláez (ed.), 85-115. Madrid: Consorcio para la Organización de Madrid Capital Europea de la Cultura.

ARDERíus, F. (1869). Teatro del Circo. Los Bufos de Arderíus, Tercera campaña (1868 a 1869). Madrid: s.e.

- (1914). De mis recuerdos. Narraciones históricas. Madrid.

CuRET, F. (1967). Teatre català. Barcelona: Aedos.

Espín TeMPLAdo, M. ${ }^{a}$ P. (1987). «El sainete del último tercio del siglo XIX: culminación de un género dramático histórico en el teatro español». Epos III, 97-122.

- (1995). El teatro por horas en Madrid (1870-1910). Madrid: Instituto de Estudios Madrileños. [Para este tipo de teatro $\mathrm{cf}$. la bibliografía reseñada por la autora.] 
FÁBREGAS, X. (1978). Historia del teatre català. Barcelona: Millà.

FuENTE Ballesteros, R. de la (1985). «En torno al Astracán». Castilla 9-10.

GARCIA LORENZO, L., ed. (1981). El teatro menor en España a partir del siglo XVI. Madrid: CSIC.

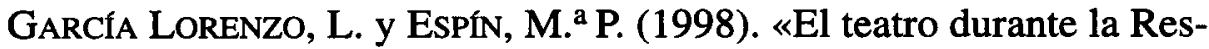
tauración y el fin de siglo: El teatro menor». En Historia de la literatura española. Siglo XIX (II), V. García de la Concha (ed.) y L. Romero Tobar (coord), t. 9, 132-142. Madrid: Espasa Calpe.

GarRido Gallardo, M. Á. (1983). «Notas sobre el sainete como género literario». En El teatro menor en España a partir del siglo XVI, L. García Lorenzo (ed.), 13-22. Madrid: CSIC.

Granja, A. de la y LoBATO, M. ${ }^{\text {a }}$ L. (1999). Bibliografía descriptiva del teatro breve español (siglos XV-XX). Madrid / Frankfurt am Main: Iberoamericana / Vervuert.

HuERTAS VÁzQUEZ, E. (1993). El teatro de los bufos madrileños. Madrid: Ayuntamiento.

IZQUIERDO IZQUIERDO, L. (1990). «El teatro menor en Valencia (18001850) (Comedias en un acto, piezas en un acto y sainetes)». Revista de Literatura 103, 101-127.

Membrez, N. J. (1987). The "Teatro por horas»: History, Dynamics and Comprehensive Bibliography of a Madrid Industry. 1867-1922 (género chico, género ínfimo and early Cinema). Santa Bárbara: Diss. University of California, 3 vols.

- (1989-90). «The "género ínfimo" in Madrid (1989-1922)». Siglo XX / XXe Century VII, 1-6.

Nicholson, H. S. (1939). «An Eighteenth Century "Entremés de costumbres"». Hispanic Review VII, 295-309.

ROMERo FERRER, A. (1990). «La literatura del género chico: hacia una bibliografía crítica». Draco. Revista de Literatura Española 2, 231-262.

- (1993). El género chico. Introducción al teatro corto fin de siglo (de su incidencia gaditana). Cádiz: Universidad.

Salaün, S. (1983). «El género chico o los mecanismos de un pacto cultural». En El teatro menor en España a partir del siglo XVI, Luciano García Lorenzo (ed.), 251-261. Madrid: CSIC. 
UNA BIBLIOGRAFÍA (SELECTA) PARA LA RECONSTRUCCIÓN DE LA VIDA ESCÉNICA...

San Martín, A. (1870). Confidencias de Arderíus. Historia de un bufo, referida por... Madrid: Imprenta Española.

VERSTEEG, M. (1999). «Los morcilleros de los teatros por horas». Gestos 14 (28), 65-79.

ZABALA, A. (1985). «Génesis de un significante de la jerga teatral: astracán, astracanada». Boletín de la Real Academia Española 65, 431-458.

\section{V.2.7. Diversiones populares y parateatro}

Álvarez Barrientos, J. y Cea Gutiérrez, A., eds. (1987). Actas de las Jornadas sobre teatro popular en España. Madrid: CSIC.

AMorós, A. (1999). «Teatro popular». En Historia de los espectáculos en España, Andrés Amorós y José M. ${ }^{\mathrm{a}}$ Díez Borque (eds.), 135145. Madrid: Castalia.

Blas Vega, J. (1987). Los cafés cantantes de Sevilla. Sevilla: Editorial Cinterco.

BoAL, A. (1972). Categorías de teatro popular. Buenos Aires: Ediciones CEPE.

Caro Baroja, J. (1969). Ensayo sobre la literatura de cordel. Madrid: Revista de Occidente.

- (1974). Teatro popular y de magia. Madrid: Revista de Occidente.

- (1980). Temas castizos. Madrid: Istmo.

- (1984). El estío festivo (Fiestas populares de verano). Madrid: Taurus.

Deleito y PiñUela, J. (1954). También se divierte el pueblo (Recuerdos de hace tres siglos). Romerías, bailes, Carnaval. Madrid: Espasa-Calpe, 2. ${ }^{a}$ ed.

- (1959). El rey se divierte. Madrid: Espasa-Calpe.

GARAMENDI AzCoRRA, M.A. (1991). El teatro popular vasco. Semiótica de la representación. San Sebastián: Diputación Foral de Guipúzcoa. 
INZENGA, J. (1898). Cantes y bailes populares de España. Madrid: A. Romero.

MARCo, J. (1977). Literatura popular en España en los siglos XVIII y $X I X$. Madrid: Taurus, 2 vols.

Pedrell y SABAté, F. (1922). Cancionero musical español. Valls: Eduardo Castell, 4 vols.

RetanA, Á. (1967). Historia de la canción española. Madrid: Tesoro.

REYes, M. de los (1989). «El teatro mecánico de la Plaza de Gavidia (Sevilla, 1859)». En Homenaje a Antonio Gallego Morell, C. Argente et alii (eds.), III, 109-126. Granada: Universidad.

SALAüN, S. (1990). El cuplé (1900-1936). Madrid: Espasa-Calpe.

SANTOS TARDón, M. ${ }^{a}$ E. (1989). «Apuntes sobre una obra de teatro popular La obra de la Iglesia de Pinarnegrillo». Revista de Folklore (Valladolid) 107, 167 y ss.

Simón Palmer, M. ${ }^{a}$ C. (1987). «Diversiones populares madrileñas en el siglo XIX». En Actas de las Jornadas sobre teatro popular en España, J. Álvarez Barrientos y A. Cea Gutiérrez (eds.), 185-192. Madrid: CSIC.

VAREY, J. E. (1997). «El teatro (I): Actividades de entretenimiento y formas parateatrales. Acróbatas, títeres, espectáculos ópticos, autómatas, circo». En Historia de la literatura española. Siglo XIX (I), V. García de la Concha (ed.) y G. Carnero (coord.), t. 8, 237-244. Madrid: Espasa Calpe.

VV.AA. (1997). Diccionario de literatura popular española. Salamanca: Colegio de España.

ZúÑIGA, Á. (1954). Historia del couplé. Barcelona: Barna.

\section{V.2.8. Títeres}

Aladro, C. L. (1976). La Tía Norica de Cádiz. Madrid: Editora Nacional.

AMADÉs, J. (1933). «Titel.les i ombres chineses». Biblioteca de Tradicions Populars VIII. 
ARTís, A. (1912). «El Pi, titel.laire dels Quatre Gats». Teatre Català I (Barcelona), p. 26.

CAmbronero, C. (1913-1914). Crónicas del tiempo de Isabel II (Publicadas en La España Moderna, en varios números de los dos años. Aparecieron también como vol. aparte).

CAPMany, A. (1921). «De marionetes i titel.les». La Revista. Quaderns de Publicació Quinzenal 7, 146-147.

Caro Baroja, J. (1987). «Los títeres en el teatro». En Actas de las Jornadas sobre teatro popular en España, J. Álvarez Barrientos y A. Cea Gutiérrez (eds.), 109-123. Madrid: CSIC.

FuENTES, E. de (1899). «En Titel.la». Quatre Gats 3, 2.

GASCH, S. (1949). Títeres y marionetas. Barcelona: Argos.

LARreA, A. de (1950). «Siglo y medio de marionetas. La Tía Norica de Cádiz». Revista de Dialectología y Tradiciones Populares 6, 583-620.

Lloret Esquerdo, J.; García Juliá, C.O. y Casado Garretas, A. (1999). Documenta Titeres 1. Alicante: Festitíteres 99. [Contiene al final una bibliografía de gran interés.]

MAGNIN, Ch. (1852). Histoire des marionettes en Europe.

PORRAS, F. (1981). Titelles. Teatro popular. Madrid: Editora Nacional.

VAREY, J. E. (1957). Historia de los títeres en España desde sus orígenes hasta mediados del siglo XVIII. Madrid: Revista de Occidente.

- (1959). Títeres, marionetas y otras diversiones populares de 1758 a 1859. Madrid: Instituto de Estudios Madrileños.

- (1960). «Los títeres en Cataluña en el siglo XIX». Estudios Escénicos V, 47-78.

- (1972). Los títeres y otras diversiones populares de Madrid: 1758-1840. Londres: Tamesis Books.

- (1996). Cartelera de los títeres y otras diversiones populares de Madrid: 1758-1840. Estudio y documentos. Londres / Madrid: Tamesis Books.

VV.AA. (1977). Les grands tradicions populars: ombres i titelles. Barcelona: Edicions 62. 
V.2.9. Pantomimas, bailes, danzas

Albaladejo IMBERnón, N., ed. (1992). Tradición y danza en España. Madrid: INAEM.

AviÑoA, X. (1987). «La danza en el Gran Teatro del Liceo. Vida coreográfica ochocentista». En Historia de la danza en Cataluña, $\mathrm{P}$. Llorens (ed.), 72-105. Barcelona: Caja de Barcelona.

BERTRÁN, M. J. (1910). Entre el telar y el foso. Valencia: Sempere.

Biosca, A. (1832). Arte de danzar. Barcelona.

CAmbronero, C. (1913-1914). Crónicas del tiempo de Isabel II (Publicadas en La España Moderna, en varios números de los dos años. Aparecieron también como vol. aparte).

CAPMANY, A. (1947). Un siglo de baile en Barcelona. Barcelona: Ediciones Librería Milla.

CAyAmeres, F. e Iglesies, J. (1971). La dansarina Roseta Mauri (1850-1923). Reus: Asociación de Estudios Reusenses.

Guest, I. (1974). Fanny Cerrito. The Life of a romantic Ballerina. Londres: Dance Books Ltd.

RuIZ MAYORDOMO, M. ${ }^{a}$ J. (1999). «Espectáculos de baile y danzas: siglo XIX». En Historia de los espectáculos en España, Andrés Amorós y José M. ${ }^{a}$ Díez Borque (eds.), 319-334. Madrid: Castalia.

VV.AA. (1992). Encuentro Internacional «La Escuela Bolera». Madrid: Ministerio de Cultura.

V.2.10. «Fantasmagoria» (con efecto de luces)

VAREY, J. E. (1955). «Robertson's Phantasmagoria in Madrid 1821». Theatre Notebook IX, 89-95; y XI (1957), 82-91. 


\section{V.2.11. Carnaval}

a) Estudios generales

Agromayor, L. (1978). España en fiestas. Madrid: Aguilar.

CARo Baroja, J. (1979). El carnaval. Análisis histórico-cultural. Madrid: Taurus.

Cox, H. (1983). Las fiestas de locos. Ensayo sobre el talante festivo y la fantasía. Madrid: Taurus.

DíAZ, J. (1999). «Espectáculos de la fiesta: Edad moderna y contemporánea». En Historia del espectáculo en España, Andrés Amorós y José M. ${ }^{a}$ Díez Borque (eds.), 239-259. Madrid: Castalia.

Gaignebet, C. (1984). El Carnaval. Ensayos de mitología popular. Barcelona: Alta Fulla.

GaRCÍA VALDÉs, C.C. (1997). «Carnaval y teatro». RILCE. Revista de Filología Hispánica 13, 25-55.

HeERs, J. (1988). Carnavales y fiestas de locos. Barcelona: Península.

Huerta Calvo, J., ed. (1989). Formas carnavalescas en el arte y la literatura. Barcelona: Serbal.

- (1999). Teatro y Carnaval. Cuadernos de Teatro Clásico 12 (Número monográfico). [Al final aparece una «Bibliografía del teatro carnavalesco», a la que remito.]

Lerouge, J. y Simón, J.Y. (1984). Le Carnaval. París: Berger-Lerault.

\section{b) Estudios en diversas zonas de España}

ANDRÉs APARICIO, S. (1990). Antropología de una fiesta granadina: el cascamorras (Guadix, Baza, Puebla de don Fadrique, Huéscar, Orce). Granada: Universidad.

ANÓNIMO (1869). El carnaval en Bilbao. Bilbao (folleto). 
ARRónIZ, M. R. (1858). El carnaval de Murcia de 1854. Murcia.

ARrónIZ, M.R. (1985). El carnaval de Velilla de la Reina. León: Diputación Provincial.

Blanco Fernández, R. (1985). El carnaval de Velilla de la Reina. León. Diputación Provincial.

Cea Gutiérez, A. (1987). «Del rito al teatro: restos de representaciones litúrgicas en la provincia de Salamanca». En Jornadas sobre el teatro popular en España, J. Álvarez Barrientos y A. Cea Gutiérrez (eds.), 25-51. Madrid: CSIC.

Esteva i CruAÑas, L1. (1985). El carnaval de Guixolenc del 1879. San Feliu de Guixols: Ajuntament.

FERNÁNDEZ DE LARRINJA, K. (1997). Mujer, ritual y fiesta. Género, antropología y teatro de carnaval en el valle de Soule. Pamplona: Lamia.

Fraguas, A. (1951). «Farsas de carnaval en Touro (Coruña)». Cuadernos de EStudios Gallegos VI, 431-441.

GARMENDiA, J. (1973). El carnaval vasco. San Sebastián: Sociedad Guipuzcoana de Estudios y Publicaciones.

Gomarín Guirado, F. (1987a). El carnaval en el Valle de Polaciones (Cantabria). Santander: Artes Gráficas Bedia.

(1987b). «Mascaradas y teatralizaciones en las Vinajeras de Cantabria». En Jornadas sobre el teatro popular en España, J. Álvarez Barrientos y A. Cea Gutiérrez (eds.), 139-163. Madrid: CSIC.

Gomarín Guirado, F. y Haya MarTínez, J.M. (1987). Juicio y muerte del Carnaval en la Villa de Santoña (Cantabria). Santander: Librería Estudio.

HÉRELLE, G. (1923). «Études sur le théâtre basque. Les tragicomedies de Carnaval». Revue International des Études Basques 14, 541-557.

HoRNILLA, T. (1988). Zamalzain el chamán y los magos del carnaval vasco: los ritos de iniciación. San Sebastián: Txertoa.

MoNTESINO GoNZÁLEZ, A., ed. (1986). Literatura satírico-burlesca del carnaval santanderino (1875-1899). Santander: Tantín.

NúÑEZ LENDOIRo, J.R. El antroido en las Mariñas dos Condes. Betanzos: Ayuntamiento. 
Palomar i Abadía, S. (1985). El carnaval urbá (Reus, 1859-1919). Reus: Agrupaçió de Colles del Carnaval.

Rodríguez PASCUAL, F. (1987). «Mascaradas de invierno en la provincia de Zamora». En Jornadas sobre el teatro popular en Espa$\tilde{n} a$, J. Álvarez Barrientos y A. Cea Gutiérrez (eds.), 122-138. Madrid: CSIC.

SADA, J.M. (1991). Carnavales donostiarras. De los origenes a nuestros días. San Sebastián: Txertoa.

Santos Perdomo, A. y Solórzano Sánchez, J. (1983). Historia del carnaval de Santa Cruz de Tenerife. Santa Cruz de Tenerife: Ayuntamiento.

VALENCIANO GAYA, L. (1981). Las mascaradas murcianas del siglo $X I X$. Bando, testamento y entierro de la sardina. Murcia: Academia Alfonso X el Sabio.

VV.AA. (1975). Madrid en sus diarios. Madrid: CSIC, 5 vols.

\section{V.2.12. Circo}

ARMERo, J. M. ${ }^{a}$ y PERNAS, R. (1985). Cien años de circo en España. Madrid: Espasa Calpe.

ARMIÑÁN, J. de (1958). Biografía del circo. Madrid: Escelicer.

Bost, P. (1931). Le cirque et le music-hall. París: Au Sans Pareil.

Castagnino, R. (1959). Centurias del circo criollo. Buenos Aires: Editorial Perrot.

- (1969). El circo criollo: datos y documentos para su historia 1757-1924. Buenos Aires: Plus Ultra.

- (1981). Circo, teatro gauchesco y tango. Buenos Aires: Instituto Nacional de Estudios de Teatro.

Castilla, A. (1986). La otra cara del circo. Madrid: Albia.

DALMAU, A. R. (1947). El circo en la vida barcelonesa. Barcelona: Millà.

GASCH, S. (1959). El circo. Barcelona: Barna.

- (1961). El circo por dentro. Barcelona: Destino. 
Gómez DE LA SERNA, R. (1956). El circo. Madrid: Imprenta Latina.

Pernas, R. (1999). «Circo». En Historia de los espectáculos en Espa$\tilde{n} a$, Andrés Amorós y José M. ${ }^{a}$ Díez Borque (eds.), 519-528. Madrid: Castalia.

TudelA, M. (1975). El techo de lona. Barcelona: Plaza \& Janés.

\section{TEATRO MUSICAL}

ALIER, R. (1982). El libro de la zarzuela. Madrid: Daimon.

- (1983). «La verbena de la Paloma»: estudio, análisis y cometarios sobre el libreto de Ricardo de la Vega y la música del maestro Tomás Bretón. Madrid: Daimón.

AlIER, R. et alii (1986). Diccionario de la zarzuela. Madrid: Daimón.

Álvarez CAÑibano, A., ed. (1995). Imágenes para la lírica. El teatro musical español a través de la estampa. 1850-1936. Madrid: Centro de Documentación Musical.

AMORós, A. (1987). «El estudio teatral de la zarzuela». En La zarzuela de cerca, A. Amorós (ed.), 9-20. Madrid: Espasa-Calpe.

- (1991). Luces de candilejas: Los espectáculos en España (1899-1939). Madrid: Espasa Calpe.

AMORós, A., ed. (1987). La zarzuela de cerca. Madrid: Espasa-Calpe.

ARDERíus, F. (1862a). La ópera y la zarzuela española. Breves consideraciones sobre el arte lírico dramático... Madrid: Imprenta Española.

- (1862b). La gran ópera y la zarzuela. Madrid: Montoya y Cía.

ARNAO, A. (1875). Dramas líricos. Madrid: Medina y Navarro.

Arnau, J. y Gómez, C. M. ${ }^{\text {a }}$ (1979). Historia de la zarzuela. Madrid: Zacosa.

ARTIS, J. (1946a). El Gran Teatro del Liceo. En Barcelona histórica y monumental, vol. VIII. 
- (1946b). Primer centenario de la Sociedad del Gran Teatro del Liceo, 1847-1947. Barcelona: Montaner y Simón. [Otra edición: Barcelona: Quintilla y Cardona, 1950.]

ASENJO BARBIERI, F. (1986). Legado Barbieri. Madrid: Fundación Banco Exterior, 2 vols.

- (1864a). La zarzuela. Madrid: José M. Ducazcal. Èdición facsímil en Madrid: Música Mundana, 1985.]

- (1864b). Contestación al maestro D. Rafael Hernando. Madrid: José M. Ducazcal.

- (1874). Discurso leído en la Academia de Bellas Artes de San Fernando el 10 de mayo de 1874 ... sobre la unión de las Bellas Artes. Madrid: Manuel Tello.

- (1877). El Teatro Real y el teatro de la Zarzuela. Madrid: José M. Ducazcal. [Edición facsímil en Madrid: Música Mundana, 1985.]

BARCE BENITO, R. (1985). Fronteras de la música. Madrid: Real Musical.

- (1987). «La ópera y la zarzuela en el siglo XIX». En Actas del Congreso Internacional «España en la música de Occidente», vol. 2. Madrid: Ministerio de Cultura /INAE.

- (1995). «El sainete lírico (1880-1915)». En La música española en el siglo XIX, E. Casares y C. Alonso (eds.), 195-244. Oviedo: Universidad.

BARCE BENITO, R., ed. (1994). Actualidad y futuro de la zarzuela. Madrid: Caja de Madrid / Alpuerto.

BARRERA MASAVER, A. (1983). Crónicas del género chico y de un Madrid divertido. Madrid: El Avapiés (3. ${ }^{a}$ ed., 1993).

BECKER, D. (1989). «El teatro lírico en tiempos de Carlos II: comedia de música y zarzuela». Diálogos Hispánicos VIII, 409-434.

Benot, E. (1894). Teatro escogido de D. Ricardo de la Vega. Madrid: Hernando.

BERTRÁN, M. J. (1905). Los maestros cantores de Nuremberg. Barcelona: Hijos de Jaime Jepús.

- (1931). El Gran Teatro del Liceo de Barcelona, 1837-1903. Barcelona: Oliva de Vilanova. 
Blas Vega, J. (1987). Los cafés cantantes de Sevilla. Madrid: Cinterco. [Dedica tres capítulos a los años 1847-1880, 1881-1900 y 1900-1936.]

BONZI, L. y BUSQUETS, L. (1995). Compagnie teatrali italiani in Spagna (1885-1913). Roma: Bulzoni.

BORREL, F. (1890). El Tanhäuser de Ricardo Wagner. Madrid: Rubiños.

- (1912). El wagnerismo en Madrid. Madrid: José M. Ducazcal.

- (1913). Los maestros cantores de Nuremberg (boceto crítico). Madrid: José M. Ducazcal.

BORRel VIDAL, J. (1945). Sesenta años de música (1876-1936). Impresiones y comentarios de un viejo aficionado. Madrid: Dossat.

Bretón, Tomás (1885). Más en favor de la ópera nacional. Madrid: Est. Tip. de Gregorio Juste.

- (1904). La ópera nacional y el Teatro Real de Madrid. Madrid: Casa Dotesio.

- (1905). La música y su influencia social. Madrid: Colonial.

- (1906). La ópera nacional. Madrid: s.e. [Edición facsímil en Madrid: Música Mundana, 1985.]

- (1995). Diarios. Madrid: Acento / Fundación Caja de Madrid, 2 vols. (Edición de Jacinto Torres Mulas).

Bretón DE los HerReros, M. (1828). Contra el furor filarmónico o más bien contra los que desprecian el teatro español. Sátira. Madrid: D. M. de Burgos.

CÁRMENA Y'MLlán, L. (1878). Crónica de la ópera italiana en Madrid desde el año 1738 hasta nuestros días. Madrid: Manuel Minuesa de los Ríos. [Prólogo del maestro Francisco Asenjo Barbieri, en el que trata desde los orígenes hasta 1738.]

CASARes Rodicio, E. (1986). Biografias y documentos sobre música y músicos españoles (legado Barbieri). Madrid: Fundación Banco Exterior (Edición, transcripción e introducción).

- (1994). Francisco Asenjo Barbieri. I. El hombre y el creador y 2. Escritos. Madrid: Instituto Complutense de Ciencias Musicales.

- (1999). «Teatro musical: zarzuela, tonadilla, ópera, revista...». En Historia de los espectáculos en España, Andrés Amorós y José M. ${ }^{a}$ Díez Borque (eds.), 147-174. Madrid: Castalia. 
UNA BIBLIOGRAFÍ (SELECTA) PARA LA RECONSTRUCCIÓN DE LA VIDA ESCÉNICA...

CASAREs, E. y Alonso Celsa (1995). La música española en el siglo $X I X$. Oviedo: Universidad.

Catálogo de la Biblioteca Musical (1946). Madrid: Ayuntamiento.

Cattaneo, M. ${ }^{\mathrm{a}}$ T. (1988). «Il libretto spagnolo: un percorso verdiano del drama al melodrama». En Forme del Melodrammatico. Parole e Musica 1700-1800, VV. AA., 21-34. Milán: Guerini e Associati.

ChaPI, Ruperto (1995). Memorias y escritos. En el segundo volumen de Ruperto Chapí, de Luis G. Iberni. Madrid: Instituto Complutense de Estudios Musicales, 2 vols.

CORTIzo, E. (1993). La restauración de la zarzuela en el Madrid del $X I X$. Madrid: Universidad Complutense (Tesis de doctorado).

COTARELO Y MORI, E. (1917). Orígenes y establecimiento de la ópera en España hasta 1800. Madrid: Imprenta de la Revista de Archivos, Bibliotecas y Museos.

- (1934). Historia de la zarzuela, o sea del drama lírico en Espa$\tilde{n} a$, desde su origen a fines del siglo XIX. Madrid: Imprenta de la Revista de Archivos, Bibliotecas y Museos.

Deleito y Piñuela, J. (s. a.). Estampas del Madrid teatral fin de siglo. I. Español. Comedia. Princesa. Novedades. Lara. Madrid: Saturnino Calleja.

- (1949). Origen y apogeo del género chico. Madrid: Revista de Occidente.

- (1954). También se divierte el pueblo (Recuerdos de hace tres siglos). Romerías, Verbenas, Bailes, Carnaval. Madrid: EspasaCalpe, 2. ${ }^{\mathrm{a}}$ ed. [Madrid: Alianza, 1988).

- (1968). Sólo Madrid es Corte. Madrid: Alianza, 3. ${ }^{\mathrm{a}}$ ed.

- (1988). El rey se divierte. Madrid: Alianza.

Delgado CABreRA, A. (1987). Libretos de ópera franceses del siglo XIX: una escritura olvidada. Madrid: Universidad Complutense (Tesis de Doctorado).

- (1990). «Censura y sátira en el Segundo Imperio. Aspectos críticos de la opereta clásica francesa». Anuario Centro Asociado de Las Palmas (UNED) 6, 19-24.

- (1991). «La leyenda del Conde Ory: el problema de los orígenes y las fuentes literarias». Epos VII, 409-422. 
- (1992). «A propósito de Le comte Ory: Farmoutier, Rossini, Mozart». Epos VIII, 485-488.

Díaz de Escovar, N. y LASSo de la Vega, P. (1924). Historia del teatro español. Comediantes. Escritores. Curiosidades escénicas. Barcelona: Montaner y Simón.

DOMÉNECH RICO, F., ed. (1998). La zarzuela chica madrileña: «La Gran Vía», "La verbena de la Paloma», "Agua, azucarillos y aguardiente», «La Revoltosa». Madrid: Castalia / Comunidad de Madrid.

DUFOURCQ, N. (1974). Breve historia de la música. México: FCE, $2 .^{a}$ ed.

DUMESNIL, R. (1957). Historia del teatro lírico. Barcelona: Vergara.

ESPERANZA y Sola, J. M. ${ }^{a}$ (1906). Treinta años de crítica musical. Madrid: Tip. de la Viuda e Hijos de Tello.

EsPín TeMPLADO, M. ${ }^{a}$ P. (1987a). «La zarzuela: esquema de un género español» (21-35) y «Jacinto Benavente, autor de género chico» (163-205). En La zarzuela de cerca, A. Amorós (ed.). Madrid: Espasa-Calpe.

- (1987b). «El sainete del último tercio del siglo XIX: culminación de un género dramático histórico en el teatro español». Epos III, 97-122.

- (1988). El teatro por horas en Madrid (1870-1910). Madrid: Universidad Complutense, 2 vols. [Tesis de doctorado. Cf. Espín, 1995.]

- (1992). «El casticismo del género chico». En Casticismo y literatura en España, Ana-Sofía Pérez Bustamente y Alberto Romero Ferrer (eds.), 25-58. Cádiz: Universidad.

- (1995). El teatro por horas en Madrid (1870-1910). Madrid: Instituto de Estudios Madrileños / Fundación Jacinto e Inocencio Guerrero.

FALla, M. de (1972). Escritos sobre música y músicos. Madrid: Espasa-Calpe, 3. ${ }^{a} \mathrm{ed}$.

FARGAS y SOlER, A. (1853). Diccionario de música. Barcelona: Verdaguer.

FERNÁNDEZ-CiD, A. (1975). Cien años de teatro musical en España (1875-1975). Madrid: Real Musical. 
FuENTE BALleSteros, R. de la (1990). «La pervivencia de la comedia áurea en la zarzuela». Cuadernos de Teatro Clásico 5, 209-217.

Fuentes Pérez, A. (1987). «Bibliografía crítica de la zarzuela». En La zarzuela de cerca, A. Amorós (ed.), 231-268. Madrid: EspasaCalpe.

FundaCión JuAN MARCh (1991). Catálogo de libretos españoles del siglo XIX. Madrid: Fundación Juan March.

GALLEGO, A. (1982). «Introducción al estudio de la ópera española en el siglo XIX». Cuadernos de Música 1-2.

GAMOND, P. (1988). Guía ilustrada de compositores de ópera. Madrid: Mondadori.

GARAYOA, M. (1982). La zarzuela. Madrid: Prensa Española.

Garcia de la Vega, J. (1959). El género lírico. Madrid: Publicaciones Españolas.

GARCía LoRenzo, L., ed. (1993). Ramos Carrión y la zarzuela. Zamora: Institución Florián de Ocampo / I.E.Z.

Gies, D. T. (1989). «Entre drama y ópera: la lucha por el público teatral en la época de Fernando VII». Bulletin Hispanique 91, 37-60.

Gómez Amat, C. (1984). Historia de la música española. Siglo XIX. Madrid: Alianza.

GOMEZ GARCIA, J. (1956). Los problemas de la ópera española. Madrid: Campano.

Gómez LABAD, J. M. ${ }^{a}$ (1983). El Madrid de la zarzuela: visión regocijada de un paseo en cantables. Madrid: Juan Piñeiro (Antología).

GonZÁlez ARACo, M. (1897). El teatro Real por dentro, memorias de un empresario. Madrid: Imprenta de los Hijos de José Ducazcal. [2. ${ }^{a}$ ed. en 1892 y reimpresiones en 1907,1930 y 1949.$]$

HaCTHOUN, A. (1975). «Estado de los estudios sobre el género chico». Revista de Estudios Hispánicos IX, 359-369.

HAMEL, F. H. (1970). Enciclopedia de la música. Barcelona-México: Grijalbo, 3 vols.

HeRnÁNDEZ GiRBal, F. (1994). Cien cantantes españoles de ópera y zarzuela de los siglos XIX y XX. Madrid: Lira. 
HuERTAS VÁZquEZ, E. (1989a). Teatro musical español en el Madrid Ilustrado. Madrid: El Avapiés.

- (1989). Música y bailes escénicos españoles. Madrid: Instituto de Estudios Madrileños / CSIC.

- (1993). El teatro de los bufos. Madrid: Instituto de Estudios Madrileños / CSIC.

IBERNI, L. G. (1985). Ruperto Chapí. Madrid: Instituto Complutense de Estudios Musicales.

IGLESIAS DE SouZA, L. (1992-1997). Teatro lírico español. La Coruña: Diputación Provincial, 4 vols. [Catálogo de óperas y zarzuelas. El vol. 1 (1992) abarca las letras A-E; el vol. II (1993), etc.]

Iglesias MARTínez, N., ed. (1986-1991). Catálogo del teatro lírico español en la Biblioteca Nacional. Madrid: Ministerio de Cultura, 3 vols.

INZENGA, José (1876). Impresiones de un artista en Italia. Madrid: Víctor Sáiz.

- (1898). Cantes y bailes populares de España. Madrid: A. Romero.

JANÉS NADAL, A. (1983). La obra de Richard Wagner a Barcelona. Barcelona: Universitat de Barcelona / Fundació Vives i Casajona.

JuAN DE Águlla, J. de (1973). Ruperto Chapí y su obra lírica. Alicante: Diputación Provincial.

Jurado de la Parra, J. (1908). Los del Teatro. Semisemblanzas de actrices, autores, críticos, actores, músicos y empresas. Madrid: Ruiz Velasco Impresor (Prólogo de Sinesio Delgado).

KLOTZ, V. (1995). Zarzuelas y operetas. Un completo recorrido por un género popular de la música. Madrid: Javier Vergara Editor.

LACAL, L. (1900). Diccionario de la Música. Madrid, 3. ${ }^{2}$ ed.

LALAMA, V. (1867). Indice general, por orden alfabético, de cuantas obras dramáticas y líricas han sido aprobadas por la Junta de Censura y censores de oficio, para todos los teatros del reino y de Ultramar (1850-1866). Madrid: Imprenta de G. Alhambra.

LAVIGNAC, A., ed. (1913). Enciclopédie de la musique et dictionnaire $d u$ Conservatoire. París: Delagrave, 11 vols. 
LeÓN Tello, F. (1998). «El teatro durante la Restauración y el fin de siglo. Apéndice: El teatro musical español durante el siglo XIX». En Historia de la literatura española. Siglo XIX (II), V. García de la Concha (ed.) y L. Romero Tobar (coord), t. 9, 150-183. Madrid: Espasa Calpe. [Sobre ópera, zarzuela y género chico, con un enclave de J. Álvarez Barrientos, «Los bufos y otras formas musicales», 170-172.]

Llopis Carbonell, C. (1992). La zarzuela en sus distintas etapas. Alcoy: Edición del Autor.

LÓPEZ-CALÓ, J. (1983). Historia de la música española. Madrid: Alianza, varios vols.

LóPez-ChaVARri ANDúJAR, E. y Doménech PRAT, J. (1978). Cien años de música valenciana. 1878-1978. Valencia: Caja de Ahorros.

Lozano Guirao, P. (1963). Vida y obra de Ricardo de la Vega. Murcia: Imprenta Nogués.

LUZURIAGA, G. (1993). Del absurdo a la zarzuela: glosario dramático, teatral y crítico. Ottawa: Girol Books Inc.

MARTín de SAgarmínaga, J. (1997). Diccionario de cantantes líricos españoles. Madrid: Acento / Fundación Caja de Madrid. [Semblanzas biográficas de más de 200 cantantes, características artísticas y, en su caso, referencias discográficas de intérpretes comprendidos entre 1870 y 1980 .]

Martínez Olmedilla, A. (1947). Los teatros de Madrid (Anecdotario de la farándula madrileña). Madrid: Ed. J. Ruiz Alonso.

- (1950). El maestro Barbieri y su tiempo (El madrileño que dignificó la tonadilla). Madrid: Imprenta Sáez / Ediciones Españolas.

MARTínez RÜCKER, C. (1990). La herencia de Wagner. Córdoba: Diario de Córdoba (Prólogo de Tomás Bretón).

Membrez, N. J. (1987). The «Teatro por horas». History, Dynamics and Comprehensive Bibliography of a Madrid Industry, 1867-1922 (género chico, género ínfimo and Early Cinema), 3 vols. [Tesis de doctorado, Microfilms Internacional.]

Mesonero Romanos, R. de (1967). «La filarmonía». En Obras completas, C. Seco Serrano (ed.), I, 175-178. Madrid: Atlas (BAE CXCIX). 
Mituana, R. (1905). Discantes y contrapuntos (crítica e historia). Valencia: F. Sempere y Cía.

- (1909). Para música vamos. Valencia.

- (1922). Ensayos de crítica musical. Madrid.

Moreno Mengíbar, A. (1994). La ópera en Sevilla (1731-1992). Sevilla: Universidad.

MuÑoz, M. (1945). Historia del Teatro Real. Madrid: Tesoro.

- (1946). Historia de la zarzuela y del género chico. Madrid: Tesoro.

- (1965 y 1970). Historia del teatro dramático en España: II. La ópera y el Teatro Real; y III. La zarzuela y el género chico. Madrid: Tesoro / Siglo XX, 3 vols.

NiEVA, F. (1990). Esencia y paradigma del género chico. Madrid: RAE.

Pedrell y Sabaté, F. (1891). Por nuestra música... Barcelona: Heinrich y Cía. [Edición facsímil en Madrid: Música Mundana, 1985.]

- (1922). Cancionero musical español. Valls: Eduardo Castell, 4 vols.

Peña, J. y ANglÉs, H. (1954). Diccionario de la música. Barcelona: Labor, 2 vols.

Peña y GoñI, A. (1875). Nuestra música: Barbieri. Madrid: José M.

Ducazcal.

- (1878). Impresiones musicales. Colección de crítica y literatura musical. Madrid: Minuesa de los Ríos.

- (1881). La ópera española y la música dramática en España en el siglo XIX. Apuntes históricos. Madrid: El Liberal / Zuzaya. [Reeditado parcialmente luego por Eduardo Rincón, España, desde la ópera a la zarzuela, Madrid: Alianza, 1967.]

- (1885). Contra la ópera española. Madrid.

- (1894). Cajón de sastre. Madrid: Viuda de Ducazcal.

- (1895). Cuatro cosas. Madrid: Revista de Navegación y Comercio. 
UNA BIBLIOGRAFÍA (SELECTA) PARA LA RECONSTRUCCIÓN DE LA VIDA ESCÉNICA...

Perales de la Cal, R. (1985). Papeles Barbieri. Madrid: Alpuerto.

Pérez, M. (1985). Diccionario de la música y los músicos. Madrid: Istmo, 3 vols.

Pérez Martínez, J. (1884). Anales del Teatro y de la Música. Año Primero 1883-1884. Madrid: Librería Gutenberg.

PÉREZ VIDAL, J. (1956). Galdós, crítico musical. Madrid: Biblioteca Atlántida.

PlazA, S. (1990). «La zarzuela, género olvidado o malentendido». Hispania (Los Angeles) LXXIII, 22-31.

Pouillain, C. (1982). «Apuntes sobre la vida musical en España en la época romántica». Iris 3, 189-215.

PRATs Esquembre, V. (1984). Ruperto Chapi, un hombre excepcional. Alicante: Publicación de la Asociación para la Promoción de los Subnormales.

Querol Roso, L. (1958-78). Breve historia de la música. Madrid, 2 vols.

REGIDOR ARRIBAS, R. (1991). La voz en la zarzuela. Madrid: Real Musical.

- (1996). Aquellas zarzuelas... Madrid: Alianza.

RetanA, Á. (1967). Historia de la canción española. Madrid: Tesoro.

Rfú, J. (1840). Ópera española... Barcelona: Joaquín Verdaguer.

RodrígueZ ARNÁEZ, J. M. (1992). Lucrecia Arana, jarrera castiza: la reina del género chico. Haro, La Rioja: Asociación Cultural Manuel Bartolomé Cossío.

Romero Ferrer, A. (1990). «La literatura del género chico: hacia una bibliografía crítica». Draco. Revista de Literatura Española 2, 231262.

- (1992). «Pervivencia y recursos del casticismo en la dramaturgia corta finisecular: el género chico». En Casticismo y literatura en España, Ana-Sofía Pérez-Bustamante y Alberto Romero Ferrer (eds.), 61-95. Cádiz: Universidad.

- (1993). El género chico. Introducción al estudio del teatro corto fin de siglo (de su incidencia gaditana). Cádiz: Universidad. 
Romero TOBAR, L. (1994). «Teatro y espectáculos musicales». En su obra, Panorama crítico del Romanticismo español. Madrid: Castalia.

RuBIo JiMÉNEZ, J. (1988). «El teatro musical: de la ópera al género ínfimo. El género chico». En El teatro en el siglo XIX. Historia del

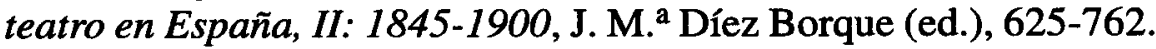
Madrid: Taurus.

RuIz AlbénIz, V., Chispero (¿1953?). Teatro Apolo. Historial, anecdotario y estampas madrileñas de su tiempo (1873-1929). Madrid: Prensa Castellana.

Rurz Silva, C. (1989). «El teatro y la ópera: un aspecto de la relación música-literatura». Ínsula 514, 5-6.

SAGARDÍA, Á. (1958a). La zarzuela y sus compositores. Madrid: Conferencias y Ensayos.

- (1958b). Federico Chueca. Pamplona: Diputación Foral de Navarra.

- (1968). Gaztambide y Arrieta. Madrid: Publicaciones Españolas.

- (1972). El compositor José Serrano, vida y obra. Madrid: Organización Sala Editorial.

- (1979). Ruperto Chapí. Madrid: Espasa-Calpe.

- (1982). Amadeo Vives. Barcelona: Nou Art Thor.

SALAüN, S. (1981). «El género chico o los mecanismos de un producto cultural». En El teatro menor en España a partir del siglo XVI, L. García Lorenzo (ed.), 251-261. Madrid: CSIC.

- (1989). «El género ínfimo: mini-culture et culture de masses». Bulletin Hispanique 91, 147-167.

- (1990). El cuplé (1900-1936). Madrid: Espasa-Calpe.

SalAzAR, A. (1930). La música contemporánea en España. Madrid: La Nave. [Edición facsímil en Oviedo: Universidad, 1982.]

- (1953). La música de España: la música en la cultura española. Buenos Aires: Espasa-Calpe.

SALDONI, B. (1868-1881). Diccionario biográfico-bibliográfico de efemérides de músicos españoles. Madrid, 4 vols. [Edición facsímil en Madrid: Ministerio de Cultura-Centro de Documentación Musical, 4 vols.] 
SÁnchez Salcedo, Á. (s.a). Francisco Asenjo Barbieri, su vida y sus obras. Madrid.

- (s.a). Ruperto Chapí, su vida y sus obras. Córdoba: Hesperia.

- (1924). Tomás Bretón, su vida y sus obras. Madrid: Biblioteca Clásica Española.

SENTAURENS, J. (1986). «Les neveux du Capitaine Grant: Jules Verne sur le tréteaux de la zarzuela». En Les productions populaires en Espagne (1850-1920), 165-193. Burdeos: CNRS.

SoPEÑA, F. (1967). Historia crítica del Conservatorio de Madrid. Madrid: Ministerio de Educación y Ciencia.

- (1976). Historia de la música española contemporánea. Madrid: Rialp.

SORIANO FUERTES, M. (1855-59). Historia de la música española desde la venida de los fenicios hasta el año de 1850. Barcelona: Narciso Ramírez, 4 vols.

SUBIRÁ, J. (1924a). El hispanismo y el italianismo musicales en la época de la tonadilla. Madrid: Revista de la Biblioteca, Archivo y Museo del Ayuntamiento.

- (1924b). Lo histórico y lo estético en la zarzuela. Madrid: Imprenta Aguirre.

- (1928-30). La tonadilla escénica. Sus obras y sus autores. Madrid: Tipografía Archivos, 3 vols.

- (1930). La participación musical en el teatro antiguo español. Barcelona: Instituto de Musicología.

- (1945). Historia de la música teatral en España. Barcelona: Labor. [Sintetiza el autor el libro de José Bilbao, Teatro Real. Recuerdos de las cinco temporadas del empresario Arana (1850-1900).]

- (1946). La ópera en los teatros de Barcelona. Estudio histórico-cronológico desde el siglo XVIII al XX. Barcelona: Millà, 2 vols. [Hay una edición reducida en Madrid: Alba, 1978.]

- (1949a). Historia y anecdotario del Teatro Real. Madrid: Plus Ultra. [Edición facsímil de Luis Suñén, Madrid: Acento / Fundación Caja de Madrid, 1997.] 
- (1949b). El compositor Iriarte (1750-1791) y el cultivo español del melólogo (melodrama). Barcelona: CSIC.

- (1950). El Teatro del Real Palacio (1849-1851). Con un bosquejo preliminar sobre la música palatina desde Felipe $V$ hasta Isabel II. Madrid: CSIC.

- (1953). Historia de la música española e hispanoamericana. Barcelona: Salvat.

- (1958). «El postrer capítulo de la Historia de la zarzuela (Último decenio del siglo XIX)». Boletín de la Real Academia Española XXXVIII, 55-92.

- (1967). Cien óperas. Autores, personajes, argumentos. Madrid: Prensa Española.

- (1971). Temas musicales madrileños (Evocaciones históricas). Madrid: Instituto de Estudios Madrileños.

- (1973). Variadas versiones de libretos operísticos. Madrid: CSIC.

Turina Gómez, J. (1997). Historia del Teatro Real. Madrid: Alianza.

VAlencia, A. (1962). El género chico (Presentación y selección de la antología de textos). Madrid: Taurus.

VALVERDE, S. (1979). El mundo de la zarzuela. Cuatro siglos del género lírico español. Madrid: Palabras.

VV.AA. (1985). Primer Seminario Internacional de Zarzuela. Madrid: Centro Español del Instituto Internacional del Teatro.

- (1986-1991). Catálogo del teatro lírico español en la Biblioteca Nacional. Libretos. Madrid: Ministerio de Cultura, 3 vols. (Dirección y prólogo de Nieves Iglesias Martínez. Contiene 7.436 fichas de libretos impresos - sin incluir manuscritos y publicaciones menores- desde las primeras óperas y zarzuelas del s. XVII hasta nuestros días).

- (1989). La zarzuela. Barcelona: Salvat (Vol. de índices de libretistas y autores).

- (1996). Actas del Congreso Internacional de la Zarzuela en España e Hispanoamérica. Madrid: SGAE.

VÁZQUEZ, M. (1884). Cartas a un amigo sobre la música en Alemania. Madrid: Biblioteca Clásica. 
VELA, F. (1965). «El género chico». Revista de Occidente, septiembre, 364-369.

Velaz DE MEDRANo, E. (1857). Álbum de la zarzuela dirigido por Don Eduardo Velaz de Medrano con la colaboración de poetas y compositores distinguidos. Madrid: Antonio Aoix.

VERSTEEG, M. (1992). «Aspectos de lo cómico en el "género chico"». Diálogos Hispánicos (Amsterdam) 10, 122-138.

Vidal Corella, V. (1973). El maestro Serrano y los felices tiempos de la zarzuela. Valencia: Prometeo.

Villalba Muñoz, L. (1914). Últimos músicos españoles del siglo $X I X$. Madrid: Ildefonso Alier.

Villarín, J. (1990). El Madrid del cuplé. Madrid: Comunidad de Madrid.

YXART, J. (1896). El arte escénico en España. Barcelona: La Vanguardia, t. II. [Reedición en Barcelona: Alta Fulla, 1987, 2 vols.]

ZaBALA, A. (1960). La ópera en la vida teatral valenciana del siglo XVIII. Valencia: Institución Alfonso el Magnánimo.

ZAMORA VicENTE, A. (1966). «El género chico levanta la cabeza». En su obra, Lengua, literatura, intimidad, 91-97. Madrid: Taurus.

ZuRITA Rodríguez, M. (1920). Historia del género chico. Madrid: Prensa Popular.

\section{ADAPTACIONES, REFUNDICIONES Y TRADUCCIONES}

Aguilar Piñal, F. (1990). «Las refundiciones en el siglo XVIII». Cuadernos de Teatro Clásico 5, 33-41.

AlBERICH, J. (1970). «El papel de Shakespeare en Un drama nuevo de Tamayo». Filología Moderna (Madrid) 10, 301-322.

Allen, J. T. (1983). The Reconstruction of a Spanish Golden Age Playhouse. El Corral del Príncipe, 1583-1744. Gainesville: University of Florida Press.

Álvarez BARrIentos, J. (1997). «El teatro (I): Traducciones, adaptaciones y refundiciones». En Historia de la literatura española. 
Siglo XIX (I), V. García de la Concha (ed.) y G. Carnero (coord.), t. 8, 275-267. Madrid: Espasa Calpe.

Bensoussan, A. (1975). «Émile Zola sur la scène espagnole: De L'Assommoir a Germinal, de Juan José a Daniel, de Joaquín Dicenta». En Melanges offerts à Charles Vincent Aubrun, 69-78. París: Éditions Hispaniques.

BRETón DE LOS HERRERos, M. (1999). Obra selecta. Teatro largo original. Logroño: Instituto de Estudios Riojanos / Universidad de la Rioja (Edición de Miguel Ángel Muro). [Vol. I: Marcela o ¿a cuál de los tres? Muérete iy verás! El pelo de la dehesa y La escuela del matrimonio; vol. II: Teatro breve original y traducido. Teatro refundido: Una de tantas, Un paseo a Bedlam (traducción) y Desde Toledo a Madrid (refundición); vol. III: Poesía, prosa. Bretón académico, edición de M. Á. Muro y Bernardo Sánchez Salas, que contiene varios artículos sobre teatro.]

CALDERA, E. (1974). Il dramma romantico in Spagna. Pisa: Università, págs. 9 y ss.

- (1980). «Da Menschenhass und Reue a Misantropia y arrepentimiento: storia di una traduzione». Studi Ispanici (Pisa), 187-209.

- (1981). «L'influenza di Shakespeare sul romanticismo spagnolo (a proposito di Romeo y Julieta di Solís-Ducis». Letterature III, 41-56.

- (1984). «La pata de cabra y Le pied de mouton». En Studia historica et philologica in honorem M. Batllori, VV. AA., 567-575. Roma: Pliegos de Cordel.

- (1990). «Bretón o la negación del modelo». Cuadernos de Teatro Clásico 5, 141-153.

CAlvet LoRA, R. M. ${ }^{\text {a }}$ (1989). «La imagen de Francia a través del teatro de Alejandro Dumas hijo». En Imágenes de Francia en las letras hispánicas, F. Lafarga (ed.), 317-326. Barcelona: PPU.

- (1990). «Versiones españolas de las obras teatrales de Alejandro Dumas (hijo). I: La dame aux camélias (1852-1930)». Epos VI, 355-375.

- (1991a). «Versiones españolas de las obras teatrales de Alejandro Dumas (hijo). II». Epos VII, 423-451. 
- (1991b). «Las versiones españolas del teatro francés en la segunda mitad del siglo XIX: Émile Augier». En Traducción y adaptación cultural: España-Francia, M. ${ }^{\mathrm{a}}$ Luisa Donaire y Francisco Lafarga (eds.), 561-577. Oviedo: Universidad.

Cobos Castro, E. (1981). Medio siglo de teatro francés en Madrid (1870-1920). Córdoba: Librería Andaluza [Edición de la autora].

- (1995). «Teatro y traducción en el siglo XIX: el papel evaluador de la crítica teatral». Investigación Franco-Española (Córdoba) $12,11-52$.

- (1998). Traducciones al castellano de obras dramáticas francesas (1830-1930). Córdoba: Universidad.

CORBIERE, A. (1927). Juan Eugenio Hartzenbusch and the French Theatre. Filadelfia: Pennsylvania University Press.

Davis, L. E. (1973). «Oscar Wilde in Spain». Comparative Literature $25,136-152$.

Dengler Gassin, R. (1986a). «El melodrama francés: su proceso de penetración en España, su proyección y acogida en las tablas madrileñas». Récifs 6, 138-160.

- (1986b). «El teatro francés en Madrid (1830-1850)». Resúmenes de Tesis de Doctorado, 1-24. Salamanca: Universidad.

- (1987). «El teatro de Victor Hugo a través de la prensa madrileña, 1835-1850». Studia Zamorensia 8, 222-233.

- (1989). «El drama romántico francés en Madrid (1830-1850)». En Imágenes de Francia en las letras hispánicas, F. Lafarga (ed.), 307-315. Barcelona: PPU.

- (1991a). «Alcance de las traducciones de obras francesas en los repertorios teatrales madrileños entre 1830 y $1850 »$. En Estudios humanísticos en homenaje a Luis Cortés Vázquez, Roberto Dengler (ed.), 161-169. Salamanca: Universidad.

- (1991b). «Algunas consideraciones a propósito de Hernani, drama de Victor Hugo (1830), versión castellana de Eugenio de Ochoa». En Traducción y adaptación cultural España-Francia, VV. AA., 337-346. Oviedo: Universidad.

Díaz-Plaja, G. (1963). «Strindberg en España». Estudios Escénicos (Barcelona) 9, 103-112. 
DONAIRE, M. ${ }^{\text {a }}$ L. y LAFARGA, F., eds. (1991). Traducción y adaptación cultural: España-Francia. Oviedo: Universidad.

DURNERIN, J. (1983a). «Larra, traducteur de Scribe et de Ducange». En Écriture des marges et mutations historiques, 41-52. París: Belles Lettres / Université de Besançon.

- (1983b). «Fascinación y repulsa por Dumas en el Larra crítico y creador». En Revisión de Larra, Albert Dérozier (ed.), 143157. Besançon: Université.

FLYNN, G. (1977). «The refundiciones of Manuel Bretón de los Herreros». Estudios Ibero-Americanos (Río Grande) 3, 257-266.

GABBERT, Th. A. (1937). "Notes on the Popularity of the Drama of Victor Hugo in Spain during the Years 1835-1845». Hispanic Review 5, 176-178.

GANElin, Ch. (1991). «Rewriting the Comedia: A Prolegomenon to a Study of the Refundición». Hispania (Wallingford) 74, 240-249.

- (1994). Rewriting Theatre. The Comedia and the XIXth Century Refundition. Lewisburg: Bucknell University Press.

GIES, D. T. (1990). «Notas sobre Grimaldi y el "furor de refundir" en Madrid (1820-1833)». Cuadernos de Teatro Clásico 5, 111-124.

GIES, D. T., ed. (1986). Juan de Grimaldi, «La pata de la cabra». Roma: Bulzoni.

GREGERSEN, H. (1936). Ibsen and Spain. Nueva York: Harvard University Press.

Hespelt, E. H. (1932). «The Translated Dramas of Mariano José de Larra and their Originals». Hispania XV, 117-134.

JIMÉNEZ MoRAles, M. ${ }^{\mathrm{a}}$ I. (1998). «Larra, crítico y traductor teatrales». En el prólogo a su edición de M. José de Larra, Un desafio. Drama en tres actos y en prosa arreglado al teatro español, 12-19. Madrid: Instituto de Estudios Madrileños.

Juliá MaRTínez, E. (1918). Shakespeare en España: Traducciones, imitaciones, influencias de las obras de Shakespeare en la literatura española. Madrid.

LAFARGA, F. (1983). Las traducciones españolas del teatro francés (1700-1835) I. Bibliografía de impresos. Barcelona: Universidad. 
- (1988a). Las traducciones españolas del teatro francés (17001835) II: Catálogo de manuscritos. Barcelona: Universidad de Barcelona.

- (1988b). «Acerca de las traducciones españolas de dramas franceses». En Coloquio Internacional sobre Teatro español del siglo XVIII, 227-237. Abano Terme: Piovan Editore.

- (1989). «Sobre el Teatro nuevo español (1800-1801); ¿español?». En Fidus interpres. Actas de las Primeras Jornadas Nacionales de Historia de la Traducción, J. C. Santoyo et alii (eds.), II, 23-32. León: Universidad / Diputación.

- (1991). «¿Adaptación o reconstrucción? Sobre Beaumarchais traducido por Bretón de los Herreros». En Traducción y adaptación cultural España-Francia, VV. AA., 159-166. Oviedo: Universidad.

LAMOND, M. (1961). «Notes on Scribe's one-act Comedies-Vaudevilles in Spain, 1820-1850». Romance Notes II.2, 89-93.

LAVAUD, J.-M. (1977). «Ibsen et le théâtre d'idées à Madrid à la fin du XIXe». En Théâtre et societé, VV. AA., 61-74. Pau: Université.

LORENZ, Ch. M. (1941). «Translated Plays in Madrid Theaters (18081818)». Hispanic Review IX, 376-382.

LoveTT, G. (1972). «Francophobia in Nineteenth-Century Spanish Letters». Kentucky Romance Quarterly XIX, 285-299.

MENARINI, P. (1980). «El problema de las traducciones en el teatro romántico». En Actas del VII Congreso de la Asociación Internacional de Hispanistas, II, 751-759. Roma: Bulzoni.

MONLEÓN, J. (1976). «Larra, autor y traductor». En Larra, escritos sobre teatro, 75-87. Madrid: Edicusa.

Olivares, D. (1989). «El tema de Inés de Castro en Francia y en España: la Inés de La Motte y la Inés de Bretón». En Imágenes de Francia en las letras hispánicas, F. Lafarga (ed.), 281-286. Barcelona: PPU.

PAR, A. (1935). Shakespeare en la literatura española. Madrid: Victoriano Suárez, 2 vols.

- (1936). Representaciones shakesperianas en España. Madrid y Barcelona: Suárez y Balmes. 
PARKer, A. y PeErs, E. A. (1933). «The Influence of Victor Hugo on Spanish Drama». Modern Language Review XXVIII, 205-216.

PeERS, E. A. (1993). «The Vogue of Alfieri in Spain». Hispanic Review I, 122-140.

Pérez-Bustamante, A. S., ed. (1998). Sección «Don Juan en el teatro». En Don Juan Tenorio en la España del siglo XX. Literatura y cine, 27-310. Madrid: Cátedra. [Es de sumo interés la bibliografía final sobre esta obra de Zorrilla y diversas versiones.]

ReEs, M. A. (1977). French Authors in Spain, 1800-1850. A Checklist. Londres: Grant \& Cutler.

ROMERo TOBAR, L. (1994). «Traducciones y difusión de los textos impresos». En su obra, Panorama crítico del Romanticismo espanol. Madrid: Castalia.

Rubio JiméneZ, J. (1998). «El teatro durante la Restauración y el fin de siglo: "Los novelistas en el teatro" y "El teatro durante la Restauración y el fin de siglo: Las traducciones del teatro europeo del fin de siglo"». En Historia de la literatura española. Siglo $X I X$ (II), V. García de la Concha (ed.) y L. Romero Tobar (coord.), t. 9, 118-121 y 142-146, respectivamente. Madrid: Espasa Calpe.

SANTA, A. (1994). «Siglo XIX: el teatro». En Historia de la literatura francesa, Javier del Prado (ed.), 1.003-1.041. Madrid: Cátedra.

Saura Sánchez, A. (1991). «Las fuentes francesas del Edipo de Martínez de la Rosa». Investigación Franco-Española (Córdoba) $5,11-46$.

SCHNEIDER, F. (1927). «Kotzebue en España: apuntes bibliográficos e históricos». Modern Philology (Chicago) 25, 179-194.

SENTAURENS, J. (1986). "Les neveux du capitaine Grant: Jules Verne sur les tréteaux de la 'zarzuela'». En Les productions populaires en Espagne 1850-1920, 165-193. París: Ed. du CNRS.

SiguÁn BoeHMER, M. (1985). «L'ideari d'Adrià Gual en el marc de la renovació del teatre català i la introducció de G. Hauptmann a Catalunya». En Homenatge a Antoni Comas, VV. AA., 435-446. Barcelona: Universidad de Barcelona.

STOUdEMIRE, S. A. (1933). «Gil y Zárate Translations of French Plays». Modern Language Notes (Baltimore) 48, 321-325. 
UMBRAL, F. (1988). «Larra, crítico teatral. Dos glosas al Anthony de Dumas». Cuadernos de Música y Teatro 2, 105-110. [Traducido por Eugenio de Ochoa, en Madrid: Imprenta José M. ${ }^{a}$ Repullés, 1836.]

Vellón LAHOZ, J. (1990). «El proceso de refundición como práctica ideológica: La dama duende de Juan José Fernández Guerra». Cuadernos de Teatro Clásico 5, 99-109.

- (1996). «Moralidad y censura en las refundiciones del teatro barroco: No hay cosa como callar, de Bretón de los Herreros». Revista de Literatura 115, 159-168.

\section{PERVIVENCIA DEL TEATRO CLÁSICO}

Adams, N. B. (1936). «Siglo de Oro Plays in Madrid: 1820-1850». Hispanic Review IV, 342-357.

AlleGRA, G. (1975). «Spagna schlegeliana: Böhl von Faber e il nuovo calderonismo». Annali dell'Instituto Universitario Orientale (Sezione Romanza, Nápoles) 17.1, 5-29.

Álvarez BARrientos, Joaquín (1995). «Revisando el teatro clásico español. La refundición de comedias en el siglo XIX». En El siglo XIX... Y la burguesía también se divierte (Actas del I Congreso de Historia y crítica del teatro de comedias), VV.AA., 27-39. El Puerto de Santa María, Cádiz: Fundación Pedro Muñoz Seca / Ayuntamiento.

Ávila Arellano, J. y Menéndez Onrubia, C. (1988). «Teatro Español. Siete meses de lucha por el arte. Homenaje a los clásicos. En torno a un texto desconocido de Galdós». Revista de Literatura 99, 171-204.

BEHLER, E. (1981). «The Reception of Calderón among the German Romantics». Studies in Romanticism (Boston) 20, 437-460.

BöHL DE FABER, J. N. y RUIZ de LARREA, F. (1818). Pasatiempo crítico en que se ventilan los méritos de Calderón. Cádiz: Imprenta Carreño.

Cabrales Artega, J. A. (1985). «Notas sobre la Edad Media en el teatro español entre 1870 y 1900». Boletín de la Biblioteca Menéndez Pelayo 61, 285-313. 
- (1986). La Edad Media en el teatro español entre 1875 y 1936. Madrid: Fundación Juan March. [Resumen de la beca de Investigación.]

CALDERA, E. (1983). «Calderón desfigurado. Sobre las representaciones calderonianas en la época prerromántica». Anales de Literatura Española de la Universidad de Alicante 2, 57-81.

- (1990). «Bretón o la negación del modelo». Cuadernos de Teatro Clásico 5, 141-153.

CARNero, G. (1978). Los orígenes del romanticismo reaccionario español: el matrimonio Böhl de Faber. Valencia: Universidad. [Para la polémica calderoniana.]

- (1982). «Juan Nicolás Böhl de Faber y la polémica dieciochesca sobre el teatro». Anales de la Universidad de Alicante-Historia Moderna 2, 291-317.

- (1990). «El teatro de Calderón como arma ideológica en el origen gaditano del Romanticismo español». Cuadernos de Teatro Clásico 5, 125-139.

Correa, G. (1970-1971). «Pérez Galdós y la tradición calderoniana». Cuadernos Hispano-Americanos 250-252, 221-241.

Dízz Borque, J. M. ${ }^{\text {a }}$, ed. (1989). Actor y técnica de representación del teatro clásico español. Londres: Tamesis Books. [Cf. especialmente los trabajos de F. Ruiz Ramón, L. García Lorenzo, R. Doménech, A. Marsillach y J. L. Pellicena sobre el actor en el teatro clásico actual.]

DURÁN, A. (1994). Discurso sobre el influjo que ha tenido la crítica moderna en la decadencia del teatro antiguo español, y sobre el modo con que debe ser considerado para juzgar convenientemente de su mérito popular. Málaga: Ágora (edición de D. L. Shaw). [1. ${ }^{\mathrm{a}}$ ed., 1828.]

EgIDO, A. (1988). «Sobre la demonología de los burladores (de Tirso a Zorrilla)». Cuadernos de Teatro Clásico 2, 37-54.

EsCOBAR, J. (1990). «El teatro del Siglo de Oro en la controversia ideológica entre españoles castizos y críticos. Larra frente a Durán». Cuadernos de Teatro Clásico 5, 155-170.

FERNÁNDEZ CABEZÓN, R. (1984). «Ataúlfo visto por dos trágicos: Agustín de Moreto y el duque de Rivas». Castilla 8, 95-100. 
- (1989). «Pervivencia de Calderón de la Barca en los albores del siglo XIX: El soldado exorcista de Gaspar Zavala y Zamora». En El teatro español a fines del siglo XVII. Historia, cultura y teatro en la España de Carlos II, J. Huerta Calvo, H. den Boer y F. Sierra (eds.), II, 623-635. Amsterdam: Rodopi. [Sobre la influencia de El Dragoncillo, de Calderón.]

FERNÁNDEZ DE MORATÍN, L. (1918). «Discurso histórico sobre los orígenes del teatro español». En Obras, 150-225. Madrid: Sucesores de Hernando.

FUENTE BALlesteros, R. de la (1990). «La pervivencia de la comedia áurea en la zarzuela». Cuadernos de Teatro Clásico 5, 209-217.

Ganelin, Ch. (1990). «Tirso de Molina'a Marta la piadosa: Recast and Reception». Gestos 10, 57-75.

- (1991). «Rewriting the Comedia: A Prolegomenon to a Study of the Refundición». Hispania (Wallingford) 74, 240-249.

- (1994). Rewriting Theatre. The Comedia and the XIXth Century Refundition. Lewisburg: Bucknell University Press.

García Lorenzo, L. (1976). «Berceo y el teatro romántico». Berceo 90, 69-82.

- (1995). «La recepción del teatro clásico en la España última». En La comedia, Jean Canavaggio (ed.), 435-460. Madrid: Casa de Velázquez.

GIES, D. T. (1990). «Notas sobre Grimaldi y el "furor de refundir" en Madrid (1820-1833)». Cuadernos de Teatro Clásico 5, 111-124.

IzQUIERDo AlBerCA, M. J. (1983). «Doña Francisquita» y «La villana». Dos zarzuelas basadas en textos de Lope de Vega. Madrid: Fundación Juan March.

- (1987). «Doña Francisquita: Lope de Vega de nuevo en solfa». En La zarzuela de cerca, A. Amorós (ed.), 129-161. Madrid: Espasa-Calpe.

José PRAdes, J. de (1960). «El teatro de Lope de Vega en los años románticos». Revista de Literatura XVIII, 235-248.

MENÉndez ONRUBiA, C. (1990). «El teatro clásico durante la Restauración y la Regencia (1875-1900)». Cuadernos de Teatro Clásico 5, 187-207. 
Menéndez OnRubia, C. y Ávila Arellano, J. (1988). «Teatro español. Siete meses de lucha por el arte. Homenaje a los clásicos. En torno a un texto desconocido de Benito Pérez Galdós». Revista de Literatura 99, 171-204.

Miguel y Canuto, J. C. de (1995). «Dionisio Solís, aventador de comedias lopianas: notas para una poética». En El siglo XIX... Y la burguesía también se divierte, M. S. Pérez Bustamante et alii (eds.), 115-130. El Puerto de Santa María (Cádiz): Ayuntamiento.

Muñoz Carabantes, M. (1992). Puesta en escena y recepción del teatro clásico y medieval en España (1939-1989). Madrid: Universidad Complutense (Tesis de Doctorado).

Palacios Fernández, E. (1990). «El teatro barroco español en una carta de Bernardo de Iriarte al conde de Aranda (1767)». Cuadernos de Teatro Clásico 5, 43-64.

PAR, A. (1935). Shakespeare en España. Barcelona: Victoriano Suárez.

Pitollet, C. (1909). La querelle caldéronienne de J. N. Böhl von Faber et J. J. de Mora. París: Felix Alcan.

PoNS, J-L. (1940). «Larra y Lope de Vega». Bulletin Hispanique XLII, 123-131.

\section{REVISTAS}

- (1983). Pipirijaina 24.

- (1987). «Debate sobre la representación actual de los clásicos» y «Debate sobre festivales». Separatas de Primer Acto 217 y 219 , respectivamente.

- (1987). Ínsula 492. [Trabajos de L. García Lorenzo, César Olico, Maria Grazia Profeti y Arturo Ramoneda sobre teatro clásico español en los escenarios.]

- (Desde 1987). Boletín de la Compañía Nacional de Teatro Clásico.

- (1990). Cuadernos de Teatro Clásico 5. Número monográfico sobre Clásicos después de los clásicos. [En el teatro de los siglos XVIII y XX. Cf. los demás números desde 1988.]

RODRf́GueZ SÁNCHEZ DE LEÓN, M. a J. (1990). «El teatro español del Siglo de Oro y la preceptiva poética del siglo XIX». Cuadernos de Teatro Clásico 5, 77-98. 
UNA BIBLIOGRAFIA (SELECTA) PARA LA RECONSTRUCCIÓN DE LA VIDA ESCÉNICA...

ROMERO TOBAR, L. (1981). «Calderón y la literatura española del siglo XIX». Letras de Deusto XI, 101-124.

RuBio JiMÉNEZ, J. (1990). «Notas sobre el teatro clásico español en el debate sobre el realismo escénico». Cuadernos de Teatro Clásico 5, 171-186.

SÁNCHEZ MARIANA, M. (1998). «Las ediciones del teatro». En Historia de la literatura española. Siglo XIX (II), V. García de la Concha (ed.) y L. Romero Tobar (coord.), 862-864. Madrid: Espasa Calpe.

SCHINASI, M. (1986). «The History and Ideology of Calderón's Reception in Mid-Nineteenth-Century Spain». Neophilologus (Amsterdam) 70, 381-396.

SHIElDS, A. K. (1933). The Madrid Stage 1820-1833. Chapel Hill: University of North Carolina Press. [Tesis de doctorado.]

Simón Díaz, J. (1963). «Los clásicos españoles en la prensa diaria de Madrid, 1830-1900». Revista de Literatura 23 (45-46), 209-240 y 24 (47-48), 201-237.

Sullivan, H. (1982). "Calderón's Reception in Spain during the Romantic Era, 1800-1850». Ottawa Hispanica (Ottawa) 4, 27-54.

Torres NebrerA, G. (1993). «Macías, de Lope a Larra: tratamiento teatral de un mito». Cuadernos para la Investigación de la Literatura Hispánica 17, 30-40.

VV.AA. (1846). «Literatura dramática». Revista Literaria de «El Español» I, 14-16. [Reseña de un debate sobre la conveniencia de imitar a los autores del XVII.]

- (1982). V Jornadas de Teatro Clásico Español. El trabajo con los clásicos en el teatro contemporáneo (Almagro, 1982). Madrid: Ministerio de Cultura.

VELlóN LAHOZ, J. (1990). «El proceso de refundición como práctica ideológica: La dama duende de Juan José Fernández Guerra». Cuadernos de Teatro Clásico 5, 99-109.

- (1994). De Trigueros a Solís. El lenguaje dramático de las refundiciones. Valencia: Universidad (Tesis de doctorado inédita).

- (1996). «Moralidad y censura en las refundiciones del teatro barroco: No hay cosa como callar, de Bretón de los Herreros». Revista de Literatura 115, 159-168. 


\section{PRÁCTICAS ESCÉNICAS ${ }^{11}$}

\section{IX.1. Aspectos generales ${ }^{12}$}

Amorós, A. (1991). Luces de candilejas. Los espectáculos en España (1898-1939). Madrid: Espasa Calpe (Prólogo de Eduardo Haro Tecglen).

BASTús, J. (1848). Curso de declamación o arte dramático. Barcelona: J. J. Olivares.

Bretón De Los Herreros, M. (1852). Progresos y estado actual del arte de la declamación en los teatros de España. Madrid: Establecimiento Tipográfico de Mellado.

CAldera, E. (1999). «Siglo XIX». En Historia de los espectáculos en España, Andrés Amorós y José M. ${ }^{a}$ Díez Borque (eds.), 87-103. Madrid: Castalia.

CALdERONe, A. (1988). «El teatro en el siglo XIX (1808-1844). La representación». En Historia del teatro en España, J. M. ${ }^{a}$ Díez Borque (ed.), II, 566-610. Madrid: Taurus.

CAPo Celada, A. (1865). Tratado de declamación. Madrid: Imprenta del Colegio de Sordomudos y de Ciegos.

Carbayo Picazo, A. (1955). «Los estudios de Preceptiva y Métrica españolas en los siglos XIX y XX». Revista de Literatura 8, 23-56.

CARNER, S. (1890). Tratado de arte escénico. Barcelona: Establecimiento Tipográfico de La Hormiga de Oro.

ClaIRON, H. (1800). Reflexiones de Mmme. Clairon, actriz de la comedia francesa sobre el arte de la declamación. Madrid: Oficina de Gerónimo Ortega (Traducción de J.D.M.).

ENCISO CASTRILLÓN, F. (1832). Principios de literatura acomodados a la declamación. Madrid: Repullés.

11 Para completar los aspectos aquí tratados remito, especialmente, al epígrafe $\mathrm{X}$ («Teatro regional»).

12 Para más datos, vid. «La Representación» (Dramaturgos, Actores, Directores, Empresas, Lugares de representación, Escenografía, Público, etc.) en el vol. de J. M. ${ }^{\mathrm{a}}$ Díez Borque (ed.), Historia del teatro en España, II. Siglo XVIII. Siglo XIX (Madrid: Taurus, 1988, 566-624 y 705-762). 
UNA BIBLIOGRAFIA (SELECTA) PARA LA RECONSTRUCCIÓN DE LA VIDA ESCÉNICA...

FUNES, E. (1894). La declamación española. Sevilla: Tipografía de Díaz y Carballo.

GARCf́ MARf́n, L. (1860). Manual de teatros y espectáculos públicos. Madrid: González.

GIES, D. T. (1996). El teatro en la España del siglo XIX. Cambridge: Cambridge University Press (Traducción de Juan Manuel Seco). [Traducción de The Theatre in Nineteenth Century Spain. Cambridge: Cambridge University Press, 1994.]

Gómez de Hermosilla, J. (1826). Arte de hablar en prosa y verso. Madrid: Imprenta Real, 2 vols.

JuRAdo de la PARRA, J. (1908). Los del Teatro. Semisemblanzas de actrices, autores, críticos, actores, músicos y empresas. Madrid: Ruiz Velasco Impresor (Prólogo de Sinesio Delgado).

LATORRE, C. (1839). Noticias sobre el arte de la declamación. Madrid: Imprenta de Yenes.

LuZÁn, I. (1974). Poética. Madrid: Cátedra.

M. M. (1848). Manual de declamación. Barcelona: Imprenta Pons y Cía.

NAVARRO TOMÁs, T. (1976). La voz y la entonación en los personajes literarios. México: Colección Málaga.

Oliva, C. y Torres Monreal, F. (1992). Historia básica del arte escénico. Madrid: Cátedra, $2 .^{\mathrm{a}} \mathrm{ed}$.

PRIETO, A. (1835). Teoría del arte cómico y elementos de oratoria y declamación para la enseñanza de los alumnos del Real Conservatorio de María Cristina. Ms. 2.804 de la Biblioteca Nacional de Madrid.

ROMEA, J. (1858). Ideas generales sobre el Arte del Teatro, para uso de los alumnos de clase de declamación del Real Conservatorio de Madrid. Madrid: Abienzo.

- (1859). Manual de declamación. Madrid: Abienzo.

- (1866). Los héroes en el teatro. Reflexiones sobre la manera de representar la trajedia. Madrid: Imprenta Francisco Abienzo.

ROMERO TOBAR, L. (1994). «Tradición y cambio en las estructuras de la vida teatral. 1. Las empresas. 2. Edificios. 3. Los actores. 4. Escenografía». En su obra, Panorama crítico del Romanticismo español. Madrid: Castalia. 
Rubio JimÉNEZ, J. (1988b). «El realismo escénico a la luz de los tratados de declamación de la época». En Realismo y Naturalismo en España en la segunda mitad del siglo XIX, Yvan Lissorgues (ed.), 257-286. Barcelona: Anthropos.

- «Don Juan Tenorio, drama de espectáculos». Cuadernos de Investigación Filológica, XV.1-2, 5-24.

SALVAT, Ricard (1995). «La comedia en el siglo XIX: entre el teatro y el espectáculo». En El siglo XIX... Y la burguesía se divierte (Actas del I Congreso sobre historia y crítica del teatro de comedias), Ana S. Pérez-Bustamante et alii (eds.), 229-236. El Puerto de Santa María: Fundación Pedro Muñoz Seca / Ayuntamiento.

SEgond, L. A. (1856). El libro de los oradores y actores. Madrid: Imprenta de Pedro Moreno (Traducción de Juan de Castro).

TALMA, F. J. (1879). Reflexiones sobre el arte teatral vertidas al castellano por Enrique Sánchez de León. Madrid: Montoya.

VAlladARES y SAAVEDRA, R. de (1848). Nociones acerca de la historia del teatro, desde su nacimiento hasta nuestros días, antecediéndola algunos principios de poética, música y declamación. Madrid: Rivadeneyra.

\section{IX.2. Actores y Compañías}

ÁlVAREZ BARRIENTOS, J. (1988). «El actor español en el siglo XVIII: formación, consideración social y profesionalidad». Revista de Literatura 50, 445-466.

- (1997). «El teatro (I): El mundo teatral desde la muerte de Fernando VII ("Actores, compañías, empresarios")». En Historia de la literatura española. Siglo XIX (I), V. García de la Concha (ed.) y G. Carnero (coord.), t. 8, 255. Madrid: Espasa Calpe.

Amorós, A. (1990). «Un actor: Isidoro Máiquez». Cuadernos Hispanoamericanos 475 , 95-102.

ARJONA y LAf́NEZ, J. (1896). La insigne artista Teodora Lamadrid. Madrid: Hijos de M. G. Hernández. 
Ávila Arellano, J. y Menéndez OnRubia, C. (1987). El Neorromanticismo español y su época. Epistolario de José Echegaray a María Guerrero. Madrid: CSIC.

BASTINOS, J. A. (1914). Arte dramático español contemporáneo. Bosquejo de autores y artistas que han sobresalido en nuestro teatro. Barcelona: Imprenta Elzeviriana.

BELDA, J. (s. a.). Máiquez, actor, guerrillero y hombre de amor. Biografía. Madrid: Nuestra Raza.

Bensoussan, A. (1982). José Yxart: 1852-1895. Théatre et critique à Barcelone. Lille: Université de Lille III / Atelier National de Reproduction des Theses, 2 vols.

BIEDER, M. (1981). «The Modern Woman on the Spanish Stage: The Contributions of Gaspar and Dicenta». Estreno 7, 25-28.

Bohígas TARragó, P. (1946). Compañías dramáticas extranjeras en Barcelona. Barcelona: Instituto del Teatro.

BONZI, L. y BUSQUETS, L. (1995). Compagnie teatrali italiane in Spagna (1885-1913). Roma: Bulzoni.

BRETÓN DE LOS HeRreros, M. (1965). «Diferentes sistemas de los actores para la representación de los dramas». En Manuel Bretón de los Herreros. Obra dispersa: «El Correo Literario y Mercantil», J. M. Díez Taboada y Juan M. Rozas (eds.), 117-118. Logroño: Instituto de Estudios Riojanos. [Aparecido en la citada publicación, el 5 de septiembre de 1831.]

BUSQUETS, L. (1987). «Companyes teatrals italianes en la Barcelona modernista». Revista de Cataluña 14, 93-111.

Calvo Revilla, L. (1920). Actores célebres del teatro del Príncipe o Español. Siglo XIX. Manera de representar de cada actor, anécdotas y datos biográficos. Madrid: Imprenta Municipal.

CARALT, R. (1944). Siete biografías de actores célebres (I. Máiquez, C. Latorre, J. Romea, J. Valero, R. Calvo, A. Vico, T. Bonaplata). Barcelona: Castell Bonet.

CARRIËRE, M.-T. (1980). «Acerca de las pensiones de actores en la Cruz y el Príncipe a mediados del siglo XIX». En Homenaje a Jean-Louis Flecniakoska, I, 119-141. Montpellier: Université Paul Valéry. 
CASTRo, J. de (1856). El libro de los oradores y actores. Madrid: Imprenta de Pedro Moreno.

CATAlina, M. (1877). Los actores. Madrid: Imprenta Central a cargo de V. Sáiz.

CHICOTE, E. (¿1943?). La Loreto y este humilde servidor (Recuerdos de la vida de dos comediantes madrileños). Madrid: Aguilar (Prólogo de Carlos Arniches y epílogo de F. José de Larra).

- (1952). Cuando Fernando VII gastaba paletó. Recuerdos y anécdotas del año de la nanita. Madrid: Inst. Edit. Reus.

- (1955). Biografía de Loreto. Madrid: Instituto Reus.

Cobos Castro, E. (1991). «La actriz María Tubau y los personajes femeninos del teatro de Sardou». Estudios de Investigación Franco-Española 4, 153-171.

Colao, A. (1980). Máiquez, discípulo de Talma. Cartagena: Ayuntamiento.

COQUELIN, C. (1890). «El arte del actor». La Ilustración Artística 4VI-1890, 82-87 y 11-VIII-1890, 99-102.

- (1910). El arte del actor. Barcelona: Millà (Traducción de Luis Castillo Buniach).

COTARElo Y MORI, E. (1896-1888). Estudios sobre el arte escénico en España. M. ${ }^{a}$ Rosario Ladvenante y Quirante, primera dama de los teatros de la Corte. Madrid: s.e., 2 vols.

- (1897). María Rosario Fernández «La Tirana». Madrid: Rivadeneyra.

- (1902). Isidoro Máiquez y el teatro de su tiempo. Madrid: Imprenta de José Perales y Martínez.

Deleito y PIÑUela, J. (s.a.). Estampas del Madrid teatral fin de siglo. Madrid: Saturnino Calleja.

DíAZ DE Escovar, N. (1916). Intimidades de la farándula. Colección de artículos referentes a la escena, comediantes y escritores dramáticos desde el siglo XVI hasta el día. Cádiz: Editorial España y América.

Díaz de Escovar, N. y LASSo de LA VeGA, F. (1924). Historia del teatro español. Comediantes. Escritores. Curiosidades escénicas. Barcelona: Montaner y Simón, 2 vols. 
DíEZ DE REVENGA, F. J. (1968). «El teatro de la época realista y el actor Julián Romea». En Julián Romea, primer centenario (1868-1968), VV. AA., 87-96. Murcia: Ayuntamiento.

DuFfey, Frank M. (1942). «Juan de Grimaldi and the Madrid Stage». Hispanic Review X, 147-156.

ESPINA, A. (1935). Romea o el comediante. Madrid: Espasa-Calpe. [Sobre el actor (1813-1868) y el teatro de su época.]

- (1967). «Julián Romea, un príncipe de la escena». En Seis vidas españolas (último capítulo). Madrid: Taurus.

Ezama GIL, Á. (1989). «Un artículo olvidado de Clarín sobre María Guerrero». Boletín del Instituto de Estudios Asturianos 130, 263-274.

FERNÁNDEZ DE CÓRDOBA, F. (1966). Mis memorias íntimas, II. Madrid: Atlas ( $B A E$, CXCIII). Edición de Manuel Artola Gallego.

FERRER DEL Río, Á. (1868). «Don Julián Romea y su época en el teatro». Revista de España (Madrid) III (12), 608-627.

- (1899). Gente de bastidores (118 retratos). Madrid: Rivadeneyra.

García Castañeda, S. (1983). «Los hermanos Asquerino o el mal uso del drama histórico». En Teatro romantico spagnolo, VV. AA., 2342. Bologna: Patron.

García de Villanueva y ParRa, M. (1788). Manifiesto por los teatros españoles y sus actores. Madrid: Ibarra.

GARCÍA SÁNCHEZ, R. (1980). «Los comediantes del siglo XIX: Un drama nuevo». Hispanic Review XIVIII, 435-447.

GARCÍA VALERo, V. (1910). Crónicas retrospectivas del teatro por un viejo cómico. Madrid: Gutenberg.

- (1913). Dentro y fuera del teatro. Crónicas retrospectivas; historias, costumbres, anécdotas y cuentos. Madrid.

GIES, D. T. (1985). «Larra, Grimaldi and the Actors of Madrid». En Studies in the Spanish Eighteenth Century Spanish Literature and Romanticism in Honor of John Dowling, D. y L. J. Barnette (eds.), 113-122. Newark: Juan de la Cuesta.

- (1988). Theatre and Politics in Nineteenth Century Spain. Juan de Grimaldi as «empresario» an Goverment Agent. Cambridge: Cambridge University Press. 
- (1997). «El teatro (I): El mundo teatral hasta la muerte de Fernando VII ("Actores, compañías y empresarios" y "La actividad de Juan de Grimaldi")». En Historia de la literatura española. Siglo XIX (I), V. García de la Concha (ed.) y G. Carnero (coord.), t. 8, 245-249 y 254. Madrid: Espasa Calpe.

GIES, T. G., ed. (1986). Juan de Grimaldi, "La pata de la cabra». Roma: Bulzoni [Sobre el equipo de actores y Concepción Rodríguez, gran actriz y mujer de Grimaldi].

GRIMALDI, J. de (1835). «Concepción Rodríguez». El Artista II, 193-196.

GUERRA y Alarcón, A. (1884). Curso completo de declamación o enciclopedia de los conocimientos que necesitan adquirir los que se dedican al arte escénico. Madrid: Imprenta de F. Maroto.

Jurado De la ParRa, J. (1908). Los del teatro. Semisemblanzas de actrices, autores, críticos, actores, músicos y empresas. Madrid: R. Velasco (Prólogo de Sinesio Delgado).

LARRAZ, E. (1979). «Joseph Robrenyo et le premier théâtre catalan politique». En Hommage des hispanistes a Noël Salomon, VV. AA., 475-486. Barcelona: Laia.

- (1980). «Le statut des comédiens dans la société espagnole du début de XIXe siècle». En Culture et societé en Espagne et en Amérique Latine au XIX ${ }^{e}$ siècle, Claude Dumas (ed), 27-40. Lille: Université de Lille III.

LASERNA, J. (1914). Figuras del teatro. Madrid: Renacimiento.

LEDESMA, J. (1929). Julián Romea. Breves apuntes biográficos. Murcia: Tipografía San Francisco.

LloRdÉn, A. (1974, 1975, 1976). «Compañías de comedias en Málaga (1752-1800)». Gibralfaro $23,137-158 ; 24,169-200$ y $25,121-$ 164 , respectivamente.

MANZANo, R. (1959). ¿Quién fue María Guerrero? Barcelona: Ediciones G.P.

Martínez Olmedilla, A. (1947). Los teatros de Madrid (Anecdotario de la farándula madrileña). Madrid: José Ruiz Alonso.

MenÉndez OnRubia, C. (1984). El dramaturgo y los actores. Epistolario de Benito Pérez Galdós, María Guerrero y Fernando Díaz de Mendoza. Madrid: CSIC. [Interesante para el estudio de las rutas, 
repertorios, etc. de las Compañías teatrales que, partiendo de Madrid, hacían recorridos por provincias.]

- (1985). «Las "despedidas" de Antonio Vico y la crisis teatral de 1888-1893». Segismundo 41-42, 217-241.

- (1989). «María Guerrero y el teatro de la Restauración (18881894)». Cahiers de l'Université de Pau 20, 177-190.

- (1990). «El teatro clásico durante la Restauración y la Regencia (1875-1900)». Cuadernos de Teatro Clásico 5, 187-207.

Menéndez Onrubia, C. y Ávila Arellano, J. (1987). El Neorromanticismo español y su época. Epistolario de José Echegaray a María Guerrero. Madrid: CSIC.

OEHRLEIN, J. (1986). El actor en el teatro español del Siglo de Oro. Investigaciones sobre la profesión del actor y su papel dentro de la sociedad. Frankfurt: Vervuet.

Olmet, L. A. del y TorRes Bernal, J. de (1920). Los grandes españoles. María Guerrero. Madrid: Renacimiento.

PICOCHE, J.-L. (1970). «Los amantes de Teruel». Introduction, édition critique et synoptique precedée d'une étude sur le monde du théâtre à Madrid entre 1833 et 1850. París: Centre des Recherches Hispaniques, 2 vols. [Trad. ${ }^{\circ}$ castellana, abreviada, en Madrid: Alhambra, 1980).

PoBlet, J. M. (1980). Josep Robrenyo, comediant, escriptor, revolucionari. Barcelona: Edicions 62.

PRIETo, A. (Inédito). Teoría del arte cómico y elementos de oratoria y declamación para la enseñanza de los alumnos del Real Conservatorio de María Cristina. Ms. 2.804 de la Biblioteca Nacional de Madrid.

REVILlA, J. de la (1845). Vida artística de Isidoro Máiquez, primer actor de los teatros de Madrid. Madrid: Medina y Navarro I Imprenta de Miguel Burgos.

REYES, A. de los (1977). Julián Romea. El actor y su entorno (18131868). Murcia: Real Academia Alfonso X el Sabio (Prólogo de Juan Barceló Jiménez).

Rodrigo, A. (1974). Margarita Xirgu y su teatro. Barcelona: Planeta.

- (1984). Xirgu. Barcelona: Nuevo Arte Thor. 
- (1994). Margarita Xirgu. Barcelona: Círculo de Lectores (Prólogo de Ricard Salvat).

Rodríguez CÁnovas, J. (1968). Isidoro Máiquez. Cartagena: Athenas.

Rodríguez CePeda, E. (1970). «Problemas del teatro en 1800 y un documento inédito de Isidoro Máiquez». Revista de Occidente XXIX (87), 357-364.

RODRíGUEZ-Solf́s, E. (1903). Guía artística. Reseña histórica del teatro y la declamación y nociones de poesía y literatura dramática. Madrid: Hijos de E. Álvarez.

Román, Manuel (1995). Los dos primeros volúmenes (de un total de once). [La editorial Royal Books de Barcelona ha iniciado la publicación de una nueva colección, Los Cómicos, en la que se abordarán la trayectoria de las más importantes figuras del cine, el teatro y la televisión en España. Se repasa la trayectoria de María Guerrero, Enrique Borrás, Margarita Xirgu, Rafael Rivelles, Antonio Moreno, etc.]

ROMEA, J. (1858). Ideas generales sobre el Arte del teatro, para uso de los alumnos de la clase de declamación del Real Conservatorio de Madrid. Madrid: Abienzo.

- (1866). Los héroes en el teatro. Reflexiones sobre la manera de representar la tragedia. Madrid.

RuBio, Pepe (1927). Mis memorias. Treinta y nueva años de actor y catorce de profesor numerario de declamación del Real Conservatorio de Madrid. Madrid: Librería Española y Extranjera / F. Beltrán. [Actor muy vinculado a Matilde Rodríguez. Los dos inauguraron el Teatro Cómico, una vez reformado el Salón Capellanes (1897). Fueron pareja de éxito en el Lara y la Comedia.]

RuBio JimÉNEZ, J. (1988). «El realismo escénico a la luz de los tratados de declamación de la época». En Realismo y Naturalismo en España en la segunda mitad del siglo XIX, Y. Lissorgues (ed.), 257286. Barcelona: Anthropos.

- (1993). «Pérez Galdós director artístico del Teatro Español. Contexto y significación». En Actas del IV Congreso Internacional de Estudios Galdosianos, 527-548. Las Palmas: Cabildo Insular de Gran Canaria. 
San Martín, A. (1870). Confidencias de Arderíus. Historia de un bufo, referida por... Madrid: Imprenta Española.

SÁNCHEZ, R. G. (1980). «Los comediantes del XIX. Un drama nuevo». Hispanic Review 48, 435-447.

SÁNCHeZ EsteVAN, I. (1913). Rita Luna. Madrid: Establecimiento Tipográfico Editorial. [Ensayo biográfico-novelesco.]

- (1915). Rita Luna. Madrid: Renacimiento. [Comedia dramática sobre la actriz.]

- (1946). María Guerrero. Barcelona: Iberia.

SÁNCHEZ MARIANA, M. (1989). «Documentos sobre actores y teatros en la sección de manuscritos de la Biblioteca Nacional». En $E l$ mundo del teatro español en su Siglo de Oro: Ensayos dedicados a John E. Varey, J. M. Ruano de la Haza (ed.), 409-435. Ottawa: Dovehouse Editions Canada («Ottawa Hispanic Studies», 3).

SASSONE, F. (s. a). María Guerrero (la grande). Madrid: Escelicer.

SePúlveda, R. (1888). El corral de la Pacheca. Madrid: Fernando Fe (capítulos XVIII-XX).

ShIELDS, A. (1933). The Madrid Stage 1820-1833. Chapel Hill: University of North Carolina (cap. II, índice C: «Actors in Dramatic Companies 1820-1833»).

Sirera, J. L1. y Miralles, Remei (1997). «Representar el sainete valenciano: imágenes textuales y tradición interpretativa». En Del oficio al mito: el actor en sus documentos, Evangelina Rodríguez (ed.), II, 363-408. Valencia: Acadèmia dels Nocturns, Universitat.

SUBIRÁ, J. (1960). El gremio de representantes españoles y La Cofradía de Nuestra Señora de la Novena. Madrid: Instituto de Estudios Madrileños.

TALMA, F. J. (1879). Reflexiones sobre el arte teatral vertidas al castellano por Enrique Sánchez de León. Madrid: Montoya.

TorderA, A. (1997). «Historia e historias del teatro: la actriz Rita Luna». En Del oficio al mito: el actor en sus documentos, Evangelina Rodríguez (ed.), II, 339-359. Valencia: Acadèmia dels Nocturns, Escenes / Universitat de València. 
TORRES MARTíneZ, J. C. de (1979). «Una carta sincera de Rafael Calvo a José Echegaray». Revista de Literatura 41, 191-217.

VALlADARES y SAAVEDRA, R. de (1848). Nociones acerca de la historia del teatro, desde su nacimiento hasta nuestros días, antecediéndola algunos principios de poética, música y declamación. Madrid: Rivadeneyra.

VAREY, J. E. (1954). «Notes on English Theatrical Performers in Spain: Part I (1767-1817)». Theatre Notebook (Londres) 8, 28-29.

- (1956). «Notes on English Theatrical Performers in Spain: Part II (1583-1868)». Theatre Notebook 10, 74-79.

- (1988). «Sobre un posible diccionario de actores españoles». En Varia Bibliographica. Homenaje a Simón Díaz, 641-644. Kassel: Reichenberger.

VV.AA. (1968a). Julián Romea, primer centenario (1868-1968). Murcia: Ayuntamiento.

- (1968b). El teatro en la época realista y el actor Julián Romea. Murcia. Ayuntamiento.

VEGA, J. (1947). Máiquez, el actor y el hombre. Madrid: Revista de Occidente.

Vellón LAHOZ, J. (1995). «Isidoro Máiquez y Dionisio Solís: el actor en la evolución de la dramaturgia en el siglo XIX». En El siglo XIX. y la burguesía también se divierte. Actas del I Congreso de historia y crítica del teatro de comedias, A. S. Pérez Bustamante et alii (eds.), 370-376. El Puerto de Santa María (Cádiz): Fundación Pedro Muñoz Seca / Ayuntamiento.

- (1997). «El "justo medio" del actor: Isidoro Máiquez y sus teóricos». En Del oficio al mito: el actor en sus documentos, Evangelina Rodríguez (ed.), II, 311-337. Valencia: Acadèmia dels Nocturns, Escenes / Universitat de València.

Vico, A. (s.a. [1902]). Mis memorias (Cuarenta años de cómico). Madrid: Serrano Editor.

ZamacoIs, E. (1911). El teatro por dentro. Barcelona: Maucci.

- (1918). La carreta de Tespis. Barcelona: Maucci.

ZERGLIRCOSAC, F. E. (1800). Ensayo sobre el origen y naturaleza de las pasiones, del gesto y de la acción teatral. Madrid: Sancha. 


\section{IX.3. Empresarios}

ÁlVAREZ BARRIENTOS, J. (1997). «El teatro (I): El mundo teatral desde la muerte de Fernando VII ("Actores, compañías, empresarios")». En Historia de la literatura española. Siglo XIX (I), V. García de la Concha (ed.) y G. Carnero (coord.), t. 8, 255. Madrid: Espasa Calpe.

CASTRO, J. de (1865). Comentario joco-serio al pliego de condiciones para la subasta del Teatro Real. Madrid: Antonio Pérez Dubrull.

DufFey, F. M. (1942). «Juan de Grimaldi and the Madrid Stage (18231837)». Hispanic Review X, 147-156. [Y otros trabajos sobre él reseñados en otros epígrafes.]

GIES, D. T. (1986a). «Juan de Grimaldi y el año teatral madrileño, 1823-1824». En Actas del VIII Congreso de la Asociación Internacional de Hispanistas, 607-613. Madrid: Istmo.

- (1986b). «Inocente estupidez: La pata de cabra (1829), Grimaldi and the Regeneration of the Spanish Stage». Hispanic Review $54,375-396$.

- (1988). Theatre and Politics in Nineteenth-Century Spain: Juan de Grimaldi as Impresario and Government Agent. Cambridge: Cambridge University Press.

- (1992). «Grimaldi, Vega y el Teatro Español (1849)». En Actas del X Congreso de la Asociación Internacional de Hispanistas, A. Vilanova (ed.), II, 1.277-1.283. Barcelona: PPU.

- (1997). «El teatro (I): El mundo teatral hasta la muerte de Fernando VII ("Actores, compañías y empresarios" y "La actividad de Juan de Grimaldi")». En Historia de la literatura española. Siglo XIX (I), V. García de la Concha (ed.) y G. Carnero (coord.), t. 8, 245-249 y 254. Madrid: Espasa Calpe.

GonZÁlez ARACo, M. (1897). El Teatro Real por dentro, memorias de un empresario. Madrid: Imprenta de los Hijos de José Ducazcal. [2. a ed. en 1892 y reimpresiones en 1907, 1930 y 1949.].

JuRAdo DE la PARRA, J. (1908). Los del teatro. Semisemblanzas de actrices, autores, críticos, actores, músicos y empresas. Madrid: R. Velasco.

MarTín, G. C. (1988). «Los teatros madrileños bajo Grimaldi y Gaviria». Boletín de la Biblioteca Menéndez Pelayo LXIV, 209-222. 
MemBrez, N. J. (1987). The Teatro por horas: History, Dynamics and Comprehensive Bibliography of a Madrid Industry (1867-1922). Santa Bárbara: Diss. University of California, 3 vols.

ROMERo TOBAR, L. (1972). «Noticias sobre empresas teatrales en periódicos del siglo XIX». Segismundo 15-16, 235-279.

SUBIRÁ, J. (1945). Historia de la música teatral española. Barcelona: Labor. [Sintetiza el libro de José Bilbao, Teatro Real. Recuerdos de las cinco temporadas del empresario Arana.]

\section{IX.4. Puestas en escena}

Alonso Seoane, M. ${ }^{\mathrm{a}}$ J. (1995). «Nuevos datos sobre Abén Humeya y su estreno» [en París]. Investigación Franco-Española (Córdoba) $12,97-109$.

ANDura VARela, F. (1992). «Del Madrid teatral del XIX: la llegada de la luz, el teatro por horas, los incendios, los teatros de verano». En Cuatro siglos de teatro en Madrid, Andrés Peláez (ed.), 85-115. Madrid: Consorcio para la Organización de Madrid Capital Europea de la Cultura.

ARIAS DE Cossío, A. M. ${ }^{a}$ (1991). Dos siglos de escenografía en Madrid. Madrid: Mondadori (Prólogo de Jesús Hernández Perera).

ARmona y Murga, J. A. (1988). Memorias cronológicas sobre la representación en España. Álava: Diputación. [Ed. ${ }^{\circ}$ de E. Palacios, J. Álvarez Barrientos y M. ${ }^{\mathrm{a}}$ C. Sánchez del tratado del autor del s. XVIII.]

Ávila ARELlano, J. (1989). «La Restauración y el espectáculo teatral español en el último cuarto del siglo XIX». Cahiers de l'Université de Pau 20, 165-176.

BABLET, D. (1975). Le décor de théâtre, de 1870 à 1914. París: CNRS.

BERENGUER, Á. (1988). Los estrenos teatrales de Galdós en la crítica de su tiempo. Madrid: Consejería de Cultura de la Comunidad de Madrid.

BERTRÁN, M. J. (1910). Entre el telar y el foso. Valencia: Sempere.

Blanchard, P. (1960). Historia de la dirección teatral. Buenos Aires.

Bravo, I. (1986). L'escenografia catalana. Barcelona: Diputació de Barcelona. 
UNA BIBLIOGRAFÍA (SELECTA) PARA LA RECONSTRUCCIÓN DE LA VIDA ESCÉNICA...

Canals, S. (1896). El año teatral 1895-1896. Crónicas y documentos. Madrid: Tipografía El Nacional. [Con un art. preliminar sobre el público de Jacinto Octavio Picón.]

CARNero, G. (1989). «Recursos y efectos escénicos en el teatro de Gaspar Zavala y Zamora». Bulletin Hispanique 91.1, 21-36.

Desfretieres, B. (1962). Jean-Marie de Grimaldi et l'Espagne. París.

DíAz de Escovar, M. y LASSo de la VeGA, F. (1924). Historia del teatro español. Comediantes. Escritores. Curiosidades escénicas. Barcelona: Montaner y Simón.

GIES, D. T. (1986). Introducción a Juan de Grimaldi, La pata de cabra. Roma: Bulzoni.

GuILlén, E. (1880). «Estadística teatral, 1879». La Raza Latina (Madrid) VII (146), 14-16.

LACE, J. de (1899). Balance teatral de 1898-1899. Madrid: Imprenta de los Hijos de M.G. Hernández.

- (1900). Balance teatral en 1899-1900. Madrid: Imprenta de los Hijos de M.G. Hernández.

MANJARRÉS, J. (1875). El arte en el teatro. Barcelona: Librería de Juan y Antonio Bastinos.

MoYNET, M. J. (1885). El teatro por dentro. Maquinaria y decoraciones. Barcelona (Trad. ${ }^{\circ}$ de Cecilio Navarro).

MUÑOZ-MORILlejo, J. (1923). Escenografía española. Madrid: Real Academia de Bellas Artes de San Fernando / Imprenta Blais.

Oliva, C. y MAESTRE, R. (1992). «Espacio y espectáculo en la comedia de magia de mediados del siglo XIX». En La comedia de magia $y$ de santos, J. Blasco et alii (eds.), 421-432. Madrid: Júcar.

Oliva, C. y Torres Monreal, F. (1990). Historia básica del arte escénico. Madrid: Cátedra. [Especialmente temas V y VI.]

PICOCHE, J. L. (1985). «Les décors du drame romantique espagnol». En L'homme et l'espace dans la littérature, les arts et l'histoire en Espagne et en Amérique Latine au XIXe siècle, C. Dumas (ed.), 95109. Lille: Université de Lille III.

- (1989). «La première représentation de El zapatero y el rey $\left(2 .^{a}\right.$ parte) de Zorrilla». Bulletin Hispanique 91, 61-70. 
Rubio JiméneZ, J. «Don Juan Tenorio, drama de espectáculos». Cuadernos de Investigación Filológica, XV.1-2, 5-24.

- (1990). «Notas sobre el teatro clásico español en el debate sobre el realismo escénico». Cuadernos de Teatro Clásico 5, 171-186.

Salvat, R. (1980). La il.luminació de gas i l'espectacle del XIX a Catalunya. Barcelona: Catalana de Gas y Electricidad. [La iluminación de gas y el espectáculo del siglo XIX en Cataluña. Barcelona: Catalana de Gas y Electricidad, 1981.]

Sánchez Salas, B. (1998). «Representando a Bretón». En Bretón de los Herreros: 200 años de escenarios, M.Á. Muro (ed.), 145-161. Logroño: Instituto de Estudios Riojanos.

Simón PAlmer, M. ${ }^{a}$ C. (1989). El gas y los madrileños (1832-1936). Madrid: Gas Madrid / Espasa Calpe.

TAlma, F. J. (1879). Reflexiones sobre el arte teatral, vertidas al castellano por Enrique Sánchez de León. Madrid: Montoya.

YXART, J. (1987). El arte escénico en España. Barcelona: Alta Fulla, 2 vols. [Reedición.]

ZoLA, E. (1890). El naturalismo en el teatro (Traducción española en La España Moderna, 1890). [Interesante sobre el modo de representar.]

\section{IX.5. Lugares teatrales}

ALIER, R. (1986). El Gran Teatro del Liceo. Madrid: Ediciones Daimón.

ÁlvAREZ BARRIENTOS, J. (1997). «El teatro (I): El mundo teatral desde la muerte de Fernando VII ("Los coliseos isabelinos" y "Los teatros particulares")». En Historia de la literatura española. Siglo XIX (I), V. García de la Concha (ed.) y G. Carnero (coord.), t. 8, 264-265 y 265-267, respectivamente. Madrid: Espasa Calpe.

ANÓNIMO (1845). «Comedias caseras». Semanario Pintoresco Español (Madrid) 22, 1-VI, 170-172.

ARRónIZ, O. (1977). Teatros y escenarios del Siglo de Oro. Madrid: Gredos. 
ARTIS, J. (1946a). El Gran Teatro del Liceo. En Barcelona histórica y monumental, vol. VIII.

- (1946b). Primer centenario de la Sociedad del Gran Teatro del Liceo, 1847-1947. Barcelona: Montaner y Simón. [Otra edición: Barcelona: Quintilla y Cardona, 1950.]

ASENJo BARBIERI, F. (1877). El Teatro Real y el Teatro de la Zarzuela. Madrid: José M. Ducazcal. [Edición facsímil en Madrid: Música Mundana, 1985.]

BAILS, B. (1983). De la arquitectura civil. Murcia: Colegio de Aparejadores y Arquitectos, ed. facsímil (Con escudio de Pedro Navascués Palacio). [1. ${ }^{\mathrm{a}}$ ed., Madrid, 1789.]

Balsalobre Garcí, J. M. ${ }^{\text {a }}$ (1994). «Elementos clásicos e innovadores en los discursos académicos sobre el teatro (1825-1844)». En Los clasicismos en el arte español (Actas del X Congreso del CEHA), 367-371. Madrid: UNED / Departamento de Historia del Arte.

- (1998a). La imagen académica del teatro español decimonónico. El teatro y su censura en la Real Academia de Bellas Artes de San Fernando (1800-1870). Madrid: UNED (Tesis de doctorado en microforma, defendida en 1997).

- (1998b). «La arquitectura teatral a través de las pruebas de pensado en la Real Academia de Bellas Artes de San Fernando». Espacio, Tiempo y Forma (Madrid, UNED), Serie VII, H. ${ }^{a}$ del Arte, 11, 261-286.

Bayón Álvarez, M. (1980). Arquitecturas de papel. Madrid.

BERTRÁN, M. J. (1910). Entre el telar y el foso. Valencia: Sempere.

- (1931). El Gran Teatro del Liceo de Barcelona, 1837-1903. Barcelona: Oliva de Vilanova.

Bretón de los Herreros, M. (1831). «De las comedias caseras». Correo Literario y Mercantil, 2-XI. [También en J. M. ${ }^{a}$ Díez Taboada y J. M. Rozas (eds.), Obra dispersa, Logroño, Instituto de Estudios Riojanos, 1965, 143-144.]

Callent, L. (1897). El incendio en los teatros. Barcelona.

CARner, S. (1890). Tratado de arte escénico. Barcelona: Establecimiento Tipográfico de La Hormiga de Oro. 
CARNERO, G. (1997). «Introducción a la primera mitad del siglo XIX español». En Historia de la literatura española. Siglo XIX (I), V. García de la Concha (ed.) y G. Carnero (coord.), t. 8, XVII-C [Cf. «Literatura y teatro en la esfera familiar», XXV-XXXI.]. Madrid: Espasa Calpe.

Deleito y PiñUela, J. (s. a.). Estampas del Madrid teatral fin de siglo. I. Español. Comedia. Princesa. Novedades. Lara. Madrid: Saturnino Calleja.

FERNÁNDEZ MUÑOZ, Á. L. (1989). Arquitectura teatral en Madrid. Del Corral de Comedias al cinematógrafo. Madrid: El Avapiés.

FORNÉS Y GURREA, M. (1982). El arte de edificar. Madrid: Ediciones Poniente, ed. facsímil (Con estudio de Antonio Bonet Correa). [1. ${ }^{\mathrm{a}}$ ed., Álbum de proyectos originales de Arquitectura acompañado de lecciones explicativas para facilitar el paso a la invención a los que se dedican a este noble arte. Madrid: 1846.]

FREIRE, A. M. ${ }^{2}$ (1996). Literatura y sociedad: los teatros en casas particulares en el siglo XIX. Madrid: Ayuntamiento / Instituto de Estudios Madrileños del CSIC.

GARCÍA MARÍN, L. (1860). Manual de teatros y espectáculos públicos con la reseña histórica y descripción de las salas o circos destinados a ellos, y la distribución y numeración de sus localidades, marcada en sus once planos que se acompañan, esmeradamente litografiados. Madrid: Imprenta de Cristóbal González, 2. ${ }^{\mathrm{a}}$ ed.

GAYA NuÑo, J. A. (1961). La arquitectura española en sus monumentos desaparecidos. Madrid: Espasa-Calpe.

GRASES RIERA, J. (1904). Memoria sobre las reformas más necesarias en los teatros de Madrid para poder garantizar la seguridad de los espectadores. Madrid.

IBERNI, L. G., ed. (1992). Teatro Campoamor. Oviedo: Ayuntamiento.

JUAN MORANT, V. (1992). «Aproximación a la arquitectura de los teatros madrileños de los siglos XVIII y XIX». En Cuatro siglos de teatro en Madrid, Andrés Peláez (ed.), 53-67. Madrid: Consorcio para la Organización de Madrid Capital Europea de la Cultura.

MANJARRÉs, J. (1875). El arte en el teatro. Barcelona: Librería de Juan y Antonio Bastinos.

Martínez Olmedilla, A. (1947). Los teatros de Madrid. Madrid: Ed. J. Ruiz Alonso. 
MuÑoz, M. (1945). Historia del Teatro Real. Madrid: Tesoro.

- (1965 y 1970). Historia del teatro dramático en España: II. La ópera y el Teatro Real; y III. La zarzuela y el género chico. Madrid: Tesoro / Siglo XX, 3 vols.

Planella y Colomina, J. (1840). Exposición completa y elemental del arte de la perspectiva y aplicación de ella al palco escénico. Barcelona: Joaquín Verdaguer.

SÁNCHEZ MARIANA, M. (1989). «Documentos sobre actores y teatros en la sección de manuscritos de la Biblioteca Nacional». En El mundo del teatro español en su Siglo de Oro: Ensayos dedicados a John E. Varey, J. M. Ruano de la Haza (ed.), 409-435. Ottawa: Dovehouse Editions Canada.

SENTAURENS, J. (1989). «Le lieu théâtral à Séville au XIXe siècle. Tradition et modernité». Bulletin Hispanique XCI, 71-110.

Sepúlveda, R. (1888). El Corral de la Pacheca. Apuntes para la historia del teatro español. Madrid: Fernando Fe.

Simón Palmer, M. ${ }^{a}$ C. (1974). «Construcción y apertura de teatros madrileños en el siglo XIX». Segismundo X, 85-124. [Tirada aparte en Madrid: Instituto de Estudios Madrileños, 1975.]

- (1983). «Planos y noticias de algunos teatros madrileños del siglo XIX». En El teatro en Madrid (1583-1925). Del Corral del Príncipe al Teatro de Arte, VV. AA., 53-71. Madrid: Ayuntamiento de Madrid.

Turina Gómez, Joaquín (1997). Historia del Teatro Real. Madrid: Alianza.

VALERA, J. (1958). «Representación dramática en casa de los duques de Medinaceli». En Obras completas, III, 1.273-1.277. Madrid: Aguilar.

VV.AA. (1984). La arquitectura teatral en España. Madrid: Servicio de Publicaciones del MOPU.

- (1986). Teatro Lope de Vega. 5 aniversarios de plata. Valladolid: Caja de Ahorros Provincial.

- (1986). Teatres de Catalunya. Barcelona: Generalitat, 2 vols.

- (1989). Cens años d'espais escénics. Palma de Mallorca: Govern Balear. 
- (1992a). La arquitectura en escena: programa de rehabilitación de teatros españoles del siglo XIX. Madrid: Centro de Publicaciones.

- (1992b). Espais teatrals a la Comunitat Valenciana. Valencia: Generalitat.

\section{IX.6. Público y costumbres}

ANDiOc, R. (1974). «Teatro y público en la época de El sí de las niñas». En Creación y público en la literatura española, 96-110. Madrid: Castalia.

ANÓNIMO (1838). «Reflexiones sobre el teatro y las costumbres actuales». Semanario Pintoresco Español (Madrid) 141, 9-XII, 802-803.

DíAZ DE Escovar, N. (s. a.). Siluetas escénicas del pasado. Colección de artículos históricos de costumbres, anécdotas, biografía, etcétera, del teatro español. Barcelona: Viuda de Luis Tasso.

DfAz de Escovar, N. y LASSo de la VeGA, F. (1924). Historia del teatro español. Comediantes. Escritores. Curiosidades escénicas. Barcelona: Montaner y Simón, 2 vols.

DoAT, J. (1961). Teatro y público. Buenos Aires: Compañía General Editora.

GaRCf́ VALERO, V. (1910). Crónicas retrospectivas del teatro por un cómico viejo. Madrid: Gutenberg.

- (1913). Dentro y fuera del teatro. Crónicas retrospectivas: historias, costumbres, anécdotas y cuentos. Madrid.

GiES, D. T. (1989). «Entre drama y ópera: la lucha por el público teatral en la época de Fernando VII». Bulletin Hispanique 91, 37-60.

Johnson, C. B. (1985). «Madrid's Third "Public" Theatre». En Studies in Eighteenth-Century Spanish Literature and Romanticism in Honor of John Cjarkson Dowling, VV. AA., 99-11. Newark, Delaware: Juan de la Cuesta.

Marco, J. (1986). «Poesía y público en el siglo XIX». En su obra, Literatura popular y proletaria, 125-140. Sevilla: Universidad.

MenÉndez OnRubia, C. (1985). «Las “despedidas" de Antonio Vico y la crisis teatral de 1888-1893». Segismundo 41-42, 217-241. 
MORENO GARBAYO, N. (1957). Catálogo de los documentos referentes a diversiones públicas conservados en el Archivo Histórico Nacional. Madrid: Junta Técnica de Archivos, Bibliotecas y Museos.

Palengue, M. (1990). El poeta y el burgués (Poesía y público 18501900). Sevilla: Alfar. [Por su relación con el tema.]

Picón, J. O. (1896). Estudio preliminar al libro de S. Canals, El año teatral 1895-1896. Crónicas y documentos. Madrid: Tipografía El Nacional.

\section{IX.7. Censura y reglamentación}

ÁlvAREZ BARRIENTOS, J. (1997). «El teatro (I): El mundo teatral desde la muerte de Fernando VII ("Reglamentación, legislación reforma" y "La censura teatral")». En Historia de la literatura española. Siglo XIX (I), V. García de la Concha (ed.) y G. Carnero (coord.), t. 8, 255-261 y 262-264, respectivamente. Madrid: Espasa Calpe.

Caldera, E. (1985). «L'Inquisizione e il fanatismo religioso nel teatro spagnolo del primo Ottocento». Letterature VIII, 27-42.

Cambronero, C. (1896). «Un censor de comedias». Revista Contemporánea 101, 150-159, 292-300, 378, 385, 492-502.

CAstillo y AlBA, E. (1871). De los espectáculos dramáticos y sus relaciones con la moral pública. Madrid.

COTARELO Y MORI, E. (1904). Bibliografía de las controversias sobre la licitud del teatro en España. Madrid: Tipografía de RABM.

CuETo, L. A. (1900). «Sentido moral del teatro». En Estudios de historia y crítica literaria, 315-387. Madrid: Sucesores de Rivadeneyra. [Hay edición de 1868.]

Elton, W. E. (1974). «Autocensura en el drama galdosiano». Estudios Escénicos (Barcelona) 18, 139-154.

GARCía EsCOBAR, V. (1847). «De la censura teatral, I-III». La Luneta 37-39.

GarCía MarTín, L. (1860). Manual de teatros y espectáculos públicos. Madrid: Imprenta de Cristóbal González, $2 .^{\mathrm{a}}$ ed. 
GonZÁleZ, P.A. (1899). La inmoralidad del teatro moderno. Madrid: Imprenta del Asilo de Huérfanos del S.C. de Jesús.

GonZÁlez Palencia, Á. (1934-41). Estudio histórico sobre la censura gubernativa en España, 1800-1833. Madrid: Tipografía de la Revista de Archivos, 3 vols.

JoRNEAU, B. (1980). «Problèmes de censure entre 1844 et $1854 »$. En Culture et societé en Espagne et Amérique Latine au XIXe siècle, $\mathrm{C}$. Dumas (ed.), 63-76. Lille: Université de Lille III.

LALAMA, V. de (1867). Índice general, por orden alfabético, de cuantas obras dramáticas y líricas han sido aprobadas por la Junta de Censura y censores de oficio, para todos los teatros del reino y de Ultramar (1850-1866). Madrid: Imprenta de G. Alhambra.

MARTIN, G. C. (1986 y 1987). «Larra y el teatro: Censura, crítica e historia» I y II. Kentucky Romance Quarterly 33 y 34, 431-437 y 345350 , respectivamente.

MembreZ, N. J. H. (1992). «The Bureaucratization of the Madrid Theater: Government Censorship, Curfews an Taxation (1868-1925)». ALEC 17, 443-449.

Moreno Garbayo, M. (1957). Catálogo de documentos referentes a diversiones públicas conservados en el Archivo Histórico Nacional. Madrid: Archivo Histórico Nacional / Dirección General de Archivos y Bibliotecas.

ROMERo TOBAR, L. (1975a). «Sobre la censura de periódicos en el siglo XIX (Algunos expedientes gubernativos de 1832 a 1849)». En Homenaje a Don A. Millares Carlo, VV. AA., I, 465-500. Las Palmas: Caja Insular de Ahorros.

- (1975b). «Textos inéditos de escritores españoles del XIX relacionados con la censura gubernativa». Cuadernos Bibliográficos del CSIC 32, 89-108.

RUBIO JIMÉNEZ, J. (1984). «La censura teatral durante la época moderada: 1840-1868. Ensayo de aproximación». Segismundo 39-40, 193-231.

Rumeu de ARMAS, A. (1940). Historia de la censura literaria gubernativa en España. Madrid: Aguilar.

SCARI, R. M. (1991). «El teatro y la moral en el pensamiento de Larra». Cuadernos Americanos 178, 160-165. [Sobre los artículos de crítica teatral (1833-1835).] 
SubIRÁ, J. (1932). «La Junta de Reforma de Teatros: sus antecedentes, actividades y consecuencias». Revista de Bibliotecas, Archivos y Museos 9, 19-45.

VELLÓN LAHOZ, J. (1996). «Moralidad y censura en las refundiciones del teatro barroco: No hay cosa como callar, de Bretón de los Herreros». Revista de Literatura 115, 159-168.

ZaVALA, I. M. (1987). «La censura en la semiología del silencio: siglos XVIII y XIX». En Censura y literaturas peninsulares. Diálogos Hispánicos de Amsterdam, VV. AA., 147-157. Amsterdam / Atlanta: Rodopi.

\section{X.- TEATRO REGIONAL ${ }^{13}$}

\section{X.1. Andalucía}

\section{Almería}

NúÑEZ RuIZ, G. (1984). «El teatro en la Almería de Fernando VII». Cuadernos Hispanoamericanos 407, 102-107.

\section{Cádiz}

Actas Capitulares. Cádiz: Archivo Municipal.

Aladro, C. L. (1976). La Tía Norica de Cádiz. Madrid: Editora Nacional.

13 La primera versión de este epígrafe, ahora ampliada, la publiqué como «Teatro regional español en el siglo XIX (Bibliografía)», en José Romera, Antonio Lorente y Ana M. ${ }^{\mathrm{a}}$ Freire (eds.), Ex Libris. Homenaje al profesor José Fradejas Lebrero (Madrid: UNED, 1993, t. II, 705-718). No incluyo los trabajos generales - citados en otros epígrafes- como, por ejemplo, los de J.-F. Botrel, «El teatro en provincias bajo la Restauración. Un medio popular de comunicación», Bulletin Hispanique LXXIX (1977), 381-393; E. Allison Peers, Historia del movimiento romántico español (Madrid: Gredos, 1967, $2 .^{\mathrm{a}}$ ed. ${ }^{\circ}$, vol. I, 375-382); Leonardo Romero Tobar, Panorama crítico del romanticismo español (Madrid: Castalia, 1994, 243 y ss.); José M. ${ }^{a}$ Enguita y José-Carlos Mainer (eds.), Literaturas regionales en España (Zaragoza: Institución Fernando el Católico, 1994), etc. 
Cantos Casenave, M. (1992). «El teatro breve gaditano a mediados del siglo XIX: algunas piezas andaluzas de José Sanz Pérez». En Costumbrismo y literatura en España, Ana-Sofía Pérez-Bustamante y Alberto Romero Ferrer (eds.), 99-116. Cádiz: Universidad.

CARNero, G. (1990a). «El teatro de Calderón como arma ideológica en el origen gaditano del Romanticismo español». Cuadernos de Teatro Clásico 5, 125-139.

- (1990). «Francisca Ruiz de Larrea y el inicio gaditano del Romanticismo español». En Escritoras románticas españolas, Marina Mayoral (ed.), 119-130. Madrid: Fundación Banco Exterior.

Carpetas de los teatros Principal y Balón. Cádiz: Archivo Municipal.

CAstro, A. de (1859). Manual del viajero en Cádiz. Cádiz: Imprenta de la Revista Médica. [Para la historia del Teatro Principal, págs. 134-135.]

Corredor Álvarez, M. a J. (1995). «La música en el Cádiz de las Cortes». En El siglo XIX... Y la burguesía también se divierte, Ana S. Pérez-Bustamante Mourier et alii (eds.), 252-267. El Puerto de Santa María: Fundación Pedro Muñoz Seca / Ayuntamiento.

Guía Rosetty (publicada en Cádiz entre 1855-1902). [Crónica anual detallada de lo acontecido en la ciudad. Cf. especialmente los apartados dedicados a «Teatros» $\mathrm{y}$ «Diversiones públicas».]

LARRAZ, E. (1977). «Teatro y política en el Cádiz de las Cortes». En Actas del $V$ Congreso de la Asociación Internacional de Hispanistas, II, 571-578.

LARReA y PAlacín, A. de (1950). «Siglo y medio de marionetas: la Tía Norica de Cádiz». Revista de Dialectología y Tradiciones Populares IV (Cuaderno 4), 583-620.

- (1977). «La Tía Norica de Cádiz». En Les grans tradicions populars: ombres $i$ titelles, VV. AA., 145-150. Barcelona: Edicions 62.

León y DomíngueZ, J. M. (1897). Recuerdos gaditanos. Cádiz: Tipografía de Cabello y Lozón (cap. III).

MARTíneZ, R., ed. (1990). Teatro inédito gaditano del siglo XIX. Madrid. Sílex. 
UNA BIBLIOGRAFIA (SELECTA) PARA LA RECONSTRUCCIÓN DE LA VIDA ESCÉNICA...

Moreno Criado, R. (1975). Los teatros de Cádiz. Jerez de la Frontera: Gráficas del Exportador.

- (1985). El Gran Teatro Falla. Cádiz: Edición del Autor.

Oficios y Documentos. Cádiz: Archivo de la Academia de Bellas Artes.

Ortega CerPa, D. (1995). «El teatro de La Tía Norica en el siglo XIX». En El siglo XIX... Y la burguesía también se divierte, Ana S. Pérez-Bustamante Mourier et alii (eds.), 315-321. El Puerto de Santa María: Fundación Pedro Muñoz Seca / Ayuntamiento.

Papeles Varios. Cádiz: Biblioteca del Casino Gaditano.

ROMERo FERRER, A. (1993). El género chico. Introducción al estudio del teatro corto fin de siglo (de su incidencia gaditana). Cádiz: Universidad.

Toscano SAN GIL, M. (1985). «El teatro popular: los títeres de la Tía Norica». En Cádiz y su provincia, VV. AA. (Equipo Alfar). Sevilla: Ediciones Gever.

Vilches Dueñas, A. (1984). El teatro en Cádiz de 1867 a 1870. Madrid: UNED. [Memoria de licenciatura, inédita, dirigida por $\mathrm{J}$. Romera Castillo.]

\section{Jerez de la Frontera}

Rutz-Lagos de Castro, M. (1964). Controversias en torno a la licitud de las comedias en la ciudad de Jerez de la Frontera (años 15501825). Jerez de la Frontera: Centro de Estudios Históricos Jerezanos.

\section{Córdoba}

Amo Raigón, P. (1994). «El teatro en Córdoba. Una aproximación a la cartelera teatral de El Defensor de Córdoba en el año 1900». En Teatro siglo $X X$, Joaquín M. ${ }^{a}$ Aguirre et alii (eds.), 65-73. Madrid: Universidad Complutense / Departamento de Filología Española III de la Facultad de Ciencias de la Información. 
Costa Palacios, A. (1984). «Una panorámica del teatro en Córdoba (siglos XVI a XIX)». Axerquia (Revista de Estudios Cordobeses) 11, 247-269.

FERNÁNDEZ ARIZA, C. (1987). El teatro en Córdoba en el trienio constitucional (1820-1823). Córdoba: ICE.

GIL, R. (1892). Apuntes para la historia de la Literatura en esta provincia desde el año 1859, en que se celebraron los primeros juegos florales, hasta el próximo 1891. Córdoba: Imprenta y Papelería Catalana.

Gómez Borrego, M. ${ }^{\mathrm{a}}$ T. (1988). El teatro en Córdoba (1854-1858). Madrid: UNED. [Memoria de licenciatura, inédita, dirigida por $\mathrm{J}$. Romera Castillo.]

MoNTIS, R. de (1929). «El Teatro Principal». En Notas cordobesas, VII, 189-203. Córdoba: Imprenta del Diario de Córdoba.

Padilla Mangas, A. (1996). «Teatro en Córdoba, Jaén y Málaga en el siglo XIX». En El siglo XIX literario en las prensas de Córdoba, Jaén y Málaga. Estudio y aproximación bibliográfica, M. ${ }^{a}$ José Porro Herrera (ed.), 41-61 [especialmente 46-47 y 127-128]. Córdoba: Universidad. [Sobre obras teatrales impresas entre 18501920.]

RAMÍREZ DE ARELlano, R. (1912). Nuevos datos para la historia del teatro español. El teatro en Córdoba. Ciudad Real: Imprenta del Hospicio Provincial. [Hay edición fácsímil publicada en Córdoba: Diputación Provincial, 1997; con una «Introducción» de María José Porro, págs. V-XCIII.]

Ramírez de ARellano, T. (1973). Paseos por Córdoba o sea apuntes para su historia. Córdoba: Librería Duque y León Everest, $2 .^{\mathrm{a}}$ ed.

Ramírez de las Casas-Deza, L. M. ${ }^{a}$ (1843). Historia del teatro en Córdoba. Texto manuscrito.

SÁNCHEZ FERNÁNDEZ, A. (1991). La cultura española desde una provincia: Córdoba (1850 a las vanguardias). Córdoba: Cajasur.

SÁNCHEZ GARCÍA, L. E. (1982). «Iglesia y teatro en Córdoba a fines del siglo XVIII». Boletín de la Real Academia de Córdoba LII (103), 167-192. 


\section{Granada}

Castroviejo, A. (1927). «Notas acerca del teatro en Granada según los programas de beneficios desde 1829 a $1841 »$. En Estudios Eruditos in Memoriam de Adolfo Bonilla San Martín, VV. AA., II, 301317. Madrid.

MUÑoz RENEDo, C. (1972). La representación de moros y cristianos en Zújar (Granada). Madrid: CSIC (Departamento de Dialectología y Tradiciones Populares).

SÁEZ PÉREZ, I. E. (1979). «Notas sobre la historia del teatro en Granada». En Estudios sobre Literatura y Arte dedicados a Emilio Orozco Díaz, VV.AA., III, 239-244. Granada: Universidad.

- (1986). Aportaciones a la historia del teatro en Granada. Granada: Universidad (microfichas).

- (1989). «El teatro Cervantes de Granada». En Homenaje al profesor Antonio Gallego Morell, VV. AA., III, 175-191. Granada: Universidad.

- (1994). «Un aspecto de la historia del teatro en Granada: los arrendamientos». Revista de la Facultad de Humanidades de Jaén. Filología III.1, 61-78. [Desde 1604 al siglo XIX.]

SALVAdOR, Á. (1989). «Granada y su literatura durante la primera mitad del siglo XIX». En Homenaje al profesor Antonio Gallego Morell, VV. AA., III, 193-205. Granada: Universidad.

Tejerizo Robles, G. (1979a). «Pervivencia del teatro tradicional de tema religioso en Granada». En Estudios sobre Literatura y Arte dedicados a Emilio Orozco Díaz, VV.AA., III, 453-468. Granada: Universidad.

- (1979b). Sobre el teatro en Granada. Una comedia inédita del siglo XVIII. Granada: Universidad.

6. Jaén

Caballero Venzalá, M. (1973). Catálogo de la «Exposición bibliográfica y documental de Jaén». Separata del Boletín del Instituto de Estudios Giennenses LXIII-LXIV. 
Padilla Mangas, A. (1996). «Teatro en Córdoba, Jaén y Málaga en el siglo XIX». En El siglo XIX literario en las prensas de Córdoba, Jaén y Málaga. Estudio y aproximación bibliográfica, M. ${ }^{\mathrm{a}}$ José Porro Herrera (ed.), 41-61 [especialmente 47-48]. Córdoba: Universidad. [Sobre obras teatrales impresas entre 1850-1920.]

\section{Málaga}

DLAZ DE EsCovar, N. (1896). El teatro en Málaga. Apuntes históricos de los siglos XVI, XVII y XVIII. Málaga: Imprenta del Diario de Málaga.

LloRDÉn A. (1974, 1975, 1976). «Compañías de comedias en Málaga (1752-1800)». Gibralfaro 23, 137-158; 24, 169-200 у 25, 121-164, respectivamente.

Padilla Mangas, A. (1996). «Teatro en Córdoba, Jaén y Málaga en el siglo XIX». En El siglo XIX literario en las prensas de Córdoba, Jaén y Málaga. Estudio y aproximación bibliográfica, M. ${ }^{a}$ J. Porro Herrera (ed.), 41-61 [especialmente 48-61 y 128-135]. Córdoba: Universidad. [Sobre obras teatrales impresas entre 1850-1920.]

Pino ChICo, E. del (1974). Tres siglos de teatro malagueño. Málaga.

- (1985). Historia del teatro en Málaga durante el siglo XIX (1792-1914). Málaga: Arguval, 2 vols.

\section{Sevilla}

AgUilar Piñal, F. (1964). «Las representaciones teatrales y demás festejos públicos en la Sevilla del rey José». Archivo Hispalense 128, 251-304.

- (1968). Cartelera prerromántica sevillana. Años 1800-1836. Madrid: CSIC (Cuadernos Bibliográficos, XXII).

- (1974). Sevilla y el teatro en el siglo XVIII. Oviedo: Universidad.

Blas Vega, J. (1987). Los cafés cantantes de Sevilla. Sevilla: Editorial Cinterco. 
Bolaños Donoso, P. (1984). «La escuela-seminario teatral sevillana. Nuevas aportaciones». El Crotalón I, 749-767.

Cepedello Boiso, J. (1995). «Teoría del teatro en la prensa sevillana del XIX: La Revista de Ciencias, Literatura y Artes (1855-1860)». En El siglo XIX... Y la burguesía también se divierte (Actas del I Congreso de Historia y crítica del teatro de comedias), A.S. PérezBustamante et alii (eds.), 75-80. El Puerto de Santa María (Cádiz): Fundación Pedro Muñoz Seca / Ayuntamiento.

Chaves, M. (1900). Los teatros de Sevilla en la segunda época constitucional: 1820-23. Sevilla.

DÍAZ FERRUZ, J. (1995). «Valoraciones de la cartelera teatral sevillana (1836-1851)». En El siglo XIX... Y la burguesía también se divierte, Ana S. Pérez-Bustamante Mourier et alii (eds.), 268-279. El Puerto de Santa María: Fundación Pedro Muñoz Seca / Ayuntamiento. [Sintetiza el proyecto de investigación que realiza sobre la cartelera sevillana en los citados años.]

FORD, R. (1980). Manual para viajeros por Andalucía. Madrid. [Cf. en el libro de viajes, las págs. 89-103, para el teatro en Sevilla.]

GonZÁlez De León, F. (v.a., ms.). Crónica sevillana. [De gran interés para la cartelera teatral sevillana. Se conserva manuscrita en el Archivo Municipal de Sevilla, sección XIV, y abarca desde 1800 a 1853.]

- (1973). Noticia artística de todos los edificios públicos de esta Muy Noble Ciudad de Sevilla. Sevilla: Gráficas del Sur, reimpresión.

Moreno Mengíbar, A. (1994). La ópera en Sevilla (1731-1992). Sevilla: Universidad.

ReYes PeÑa, M. de los (1987). «El teatro de Vista Alegre: un coliseo de segundo orden en la Sevilla de la primera mitad del siglo XIX». Archivo Hispalense 214, 93-114.

- (1989). «El Teatro Mecánico de la Plaza de la Gavidia (Sevilla, 1859)». En Homenaje al profesor Antonio Gallego Morell, VV. AA., III, 109-125. Granada: Universidad. 
Reyes Peña, M. de los y Reyes Cano, R. (1984). «Algunas muestras de la relación política-teatro durante el sexenio absolutista en Sevilla (datos para una historia del teatro en Sevilla en el siglo XIX)». Archivo Hispalense 206, 41-61. [Sobre los años 1814-1820.]

Sentaurens, J. (1989). «Le lieu théâtral à Séville au XIXe siècle. Tradition et modernité». Bulletin Hispanique XCI (1), 71-110.

\section{X.2. Aragón}

Alegre Cudós, J. L. (1983). Guía del teatro en la provincia de Zaragoza. Zaragoza: Heraldo de Aragón.

GiméneZ Soler, A. (1927). «El teatro en Zaragoza antes del siglo XIX». Universidad (Zaragoza) 4, 243-296 y 571-647.

GonZÁlez MiRANDA, M. (1971). El teatro en Zaragoza en el siglo XIX. Zaragoza: Ayuntamiento de Zaragoza.

\section{X.3. Asturias}

Álvarez Salas, R. (s. a.). Noticias del teatro en Oviedo en el siglo $X I X$. Oviedo.

Álvarez Solar-QuiNTES, M. (1974). «Noticias del teatro en Oviedo durante la segunda mitad del XIX». Boletín del Instituto de Estudios Asturianos XVIII, 279-289.

Arrones, L. (1994). Teatro Campoamor. Oviedo: Instituto de Estudios Asturianos.

FERNÁNDEZ CONDE, J. (1982). «El teatro en Asturias entre el Medioevo y la Edad Moderna». Cuadernos del Norte 12, 50-53.

IBERNI, L. G., ed. (1992). Teatro Campoamor. Oviedo: Ayuntamiento. 


\section{X.4. Baleares}

\section{Mahón}

MerCadAl BAGUR, D. (1968). Ciento cincuenta años de arte lírico y dramático en el Coliseo de Mahón. Barcelona.

\section{Palma de Mallorca}

Bonet, J. (1982). Els cartells en la vida del teatre Principal. Palma de Mallorca: Consell Insular.

FERNÁNDEZ, Á. R. (1972). «Aportación al estudio del teatro en Mallorca». Mayurqa. Miscelánea de Estudios Humanísticos (Universidad de Barcelona / Estudio General Luliano de Palma de Mallorca) IX, 5-80.

LARraZ, E. (1974). «Le théâtre à Palma de Majorque pendant la Guerre d'Indépendence, 1811-1814». Mélanges de la Casa de Velázquez X, 315-355.

MAS I VIVES, J. (1986). El teatre a Mallorca a l'època romàntica. Barcelona: Curial Edicions (Publicacions de l'Abadia de Montserrat). [Abarca los años 1833-1874.]

Pons Valles, F. (1955). La Casa de las Comedias. Hoy Teatro Principal. Palma de Mallorca: E. Mallorquina de F. Pons.

Sabater Serra, G. (1982). De la Casa de las Comedias al Teatro Principal. Palma de Mallorca: Cort / Consell Insular de Mallorca.

- (1987). Teatro Principal de Palma de Mallorca. Palma de Mallorca: Cort.

SERRÀ CAMPINS, A. (1987). El teatre burlesc mallorquí, 1701-1858. Barcelona: Curial / Publicacions de l'Abadia de Montserrat.

VV.AA. (1989). Cens d'espais escènics. Palma de Mallorca: Govern Balear. 


\section{X.5. Canarias}

\section{General}

B. R. (1847). «Historia del Teatro en estas Islas». La Aurora (Semanario de Santa Cruz de Tenerife) 3 (19 de septiembre), 17-18; 4 (26 de septiembre), 25-26; 5 ( 3 de octubre), 36-37 y 7 (17 de octubre), 49-51 [Cf. especialmente la entrega del $n .^{\circ} 7$ para el siglo XIX. Rafael Fernández Hernández hará una nueva edición: Gobierno de Canarias / Viceconsejería de Cultura.]

FERNÁNDEZ HERNÁNDEZ, M. ${ }^{a}$ del P. (1995). «Compañías y obras: notas para una aproximación al teatro canario del siglo XIX». En El siglo XIX... Y la burguesía también se divierte (Actas del I Congreso de historia y crítica del teatro de comedias), Ana Sofía Pérez-Bustamante Mourier et alii (eds.), 282-287. El Puerto de Santa María (Cádiz): Fundación Pedro Muñoz Seca / Ayuntamiento.

FERnÁndeZ HeRnándeZ, R. (1991). Teatro canario (Siglos XVI al XX). Las Palmas de Gran Canaria: Edirca, 2 vols.

- (1995). «El historiador B. R. o una aproximación desde Canarias al teatro de la primera mitad del siglo XIX». En El siglo XIX... Y la burguesía también se divierte, Ana Sofía Pérez-Bustamante Mourier et alii (eds.), 81-86. El Puerto de Santa María: Fundación Pedro Muñoz Seca / Ayuntamiento.

MARTín Montenegro, S. F. (1991). «Cartelera teatral canaria (18321839)». En Homenaje al profesor Sebastián de la Nuez, VV. AA., 145-163. La Laguna: Universidad.

- (1995). «Comedias, teatros y comediantes en Canarias (18331849)». En El siglo XIX... Y la burguesía también se divierte, A. S. Pérez-Bustamante Mourier et alii (eds.), 288-308. El Puerto de Santa María: Fundación Pedro Muñoz Seca / Ayuntamiento. [Añade la «Cartelera teatral canaria (1840-1849)», págs. 299308.]

Millares TorRes, A. (1857). «[Historia del teatro en estas islas]». El Ómnibus (Las Palmas de Gran Canaria), 26 de septiembre, 1. 
UNA BIBLIOGRAFIA (SELECTA) PARA LA RECONSTRUCCIÓN DE LA VIDA ESCÉNICA...

PAdrón Acosta, S. (1954). El teatro en Canarias. La Laguna: Instituto de Estudios Canarios.

\section{Gran Canaria}

LÓPEZ CABrera, M. ${ }^{a}$ del M. (1995). El teatro en Las Palmas de Gran Canaria (1853-1900). Madrid: UNED (en microforma). [Tesis de doctorado defendida en 1995, dirigida por J. Romera Castillo.]

Rodríguez-DIAZ DE QuinTANA, M. (1978). Los arquitectos del siglo $X I X$. Las Palmas: Colegio de Arquitectos.

\section{La Palma}

AbDo Pérez, A. (1989). «Y estuvo a punto de caer». Revista Cultural "La Graja» (Cabildo Insular de La Palma) 3 (diciembre), 43 y ss.

Arvelo GIL, L. (1993). «Del Oratorio del Hospital de Dolores a Teatro Chico en Santa Cruz de La Palma». En I Encuentro de Geografía, Historia y Arte de Santa Cruz de La Palma, VV. AA., vol. II. Santa Cruz de La Palma: Patronato Municipal para la Commemoración del V. ${ }^{\circ}$ Centenario de la Fundación de Santa Cruz de La Palma.

Fernández MuÑoz, Á. L. e Inglés Musoles, F. M. a (1984). «Restauración y rehabilitación de dos teatros en Santa Cruz de La Palma». En El teatro en Santa Cruz de La Palma, VV. AA. Santa Cruz de La Palma: Ayuntamiento.

Régulo Pérez, J. (1984). «Santa Cruz de La Palma y su vida cultural». En El teatro en Santa Cruz de La Palma, VV. AA. Santa Cruz de La Palma: Ayuntamiento.

Rey, P. y ABdo Pérez, A. (1984). «Una aproximación al teatro en La Palma hasta 1936». En El teatro en Santa Cruz de la Palma, VV. AA. Santa Cruz de la Palma: Ayuntamiento. 
- (1989). «Con la rehabilitación del teatro Chico se ha recuperado parte de la historia de La Palma». En Programa de inauguración del Teatro Chico. Santa Cruz de La Palma: Ayuntamiento.

- (1995). «El teatro Chico de Santa Cruz de la Palma (1869)». En El siglo XIX... Y la burguesía también se divierte, Ana S. PérezBustamante Mourier et alii (eds.), 335-343. El Puerto de Santa María: Fundación Pedro Muñoz Seca / Ayuntamiento.

VV.AA. (1984). El teatro en Santa Cruz de La Palma. Santa Cruz de la Palma: Ayuntamiento.

\section{Tenerife}

MARTínez Viera, F. (1968). Anales del Teatro en Tenerife. Santa Cruz de Tenerife: Impr. Editorial Católica (Prólogo de Domingo Pérez Minik). [2. ${ }^{a}$ ed., Santa Cruz de Tenerife: Ayuntamiento, 1991; con prólogo de Rafael Fernández Hernández.]

\section{X.6. Cantabria}

BALSALOBRE GARCíA, J. M. ${ }^{a}$ (1998). «La arquitectura teatral a través de las pruebas de pensado en la Real Academia de Bellas Artes de San Fernando». Espacio, Tiempo y Forma (Madrid, UNED), Serie VII, H. ${ }^{a}$ del Arte, 11, 261-286. [Cf. epígrafe 1.2.2, «Proyecto de teatro para la ciudad de Santander», 272-277.]

GOMARÍN GUIRADO, F. (1987b). «Mascaradas y teatralizaciones en las

Vinajeras de Cantabria». En Jornadas sobre el teatro popular en España, J. Álvarez Barrientos y A. Cea Gutiérrez (eds.), 139-163. Madrid: CSIC.

SÁNChez Rebanal, F. (1999). El teatro en la ciudad de Santander (1898-1900). Madrid: UNED. [Memoria de Investigación inédita, dirigida por M. ${ }^{a}$ Pilar Espín Templado.] 


\section{X.7. Castilla-La Mancha}

\section{General}

GonzÁlez CASARRubios, C. (1985). Fiestas populares en Castilla-La Mancha. Ciudad Real: Junta de Castilla-La Mancha.

\section{Albacete}

CORTÉS IBÁÑEZ, E. (1991a). «Actividad escénica en Albacete en la segunda mitad del siglo XIX». Cultural Albacete 52, 3-12.

- (1991b). «Parateatro en Albacete (1884-1900)». Cultural Albacete 56, 3-14.

- (1992). «En torno al Teatro Principal de Almansa». Ensayos (Revista de la E.U.F.P. de Albacete) 7, 49-65.

- (1997). «Apuntes sobre la actividad escénica en Albacete». Cultural Albacete (noviembre), 32-33.

- (1999). El teatro en Albacete en la segunda mitad del siglo XIX. Documentos, cartelera y estudio. Albacete: Diputación / Instituto de Estudios Albacetenses «Don Juan Manuel»; con prólogo de J. Romera. [Síntesis de la tesis de doctorado, El teatro en Albacete en la segunda mitad del siglo XIX (defendida en la UNED, 1991; publicada primeramente en microforma: Madrid: UNED, 1993, dirigida por J. Romera Castillo.]

FuSTER RUIZ, F. (1973). «Pequeña historia del teatro en Albacete». Artículos publicados en la edición dominical de La Verdad -en la sección «Semanario de Albacete»-, en junio (días 3, 10, 17 y 24), julio $(1,8,15,22$ y 29$)$ y agosto (5 y 12).

- (1974). Historia del teatro en Albacete. Albacete: Imprenta Artes Gráficas Fuentes (Edición del autor). [Recopilación de artículos periodísticos.]

MATEOS ARCÁngel, A. (1963). «Orto del teatro Circo». Feria (Albacete). 
- (1983a). Evocaciones y recuerdos albaceteños, 109-111 y 122124. Albacete: Diputación.

- (1983b). Del Albacete antiguo (Imágenes y recuerdos), 105107. Albacete: Diputación.

Roa Erostarbe, J. (1891). Crónica de la provincia de Albacete I, 291294. Albacete: J. Collado.

SÁNCHEZ TORRES, F. J. (1916). Apuntes para la historia de Albacete, 155-157. Albacete: Imprenta de Eliseo Ruiz.

\section{Toledo}

ARAGonés de la ENCARNACión, A. (1929). «Aquí fue el templo de la dramática». En Toledo. Páginas de su historia. Toledo: Casa de Rafael Gómez Menor.

MARÍn GAMERo, A. (1871). Memoria dirigida al Ayuntamiento de Toledo para proponer el nombre del Teatro de Rojas al nuevo coliseo que se levantaba. Toledo: Imprenta Cea.

TORRES LARA, A. (1996). La escena toledana en la segunda mitad del siglo XIX. Madrid: UNED. [Tesis de doctorado inédita, dirigida por José Romera Castillo.]

\section{X.8. Castilla y León}

\section{General}

Alonso Ponga, J. L. (1986). Religiosidad popular navideña en Castilla y León. Manifestaciones de carácter dramático. Salamanca: Junta de Castilla y León.

\section{Astorga}

Alonso Luengo, L. (1986). El teatro en Astorga. León: Santiago García. 
3. Ávila

BERNALDo De Quirós Mateo, J. A. (1994). «Recopilación de datos para una historia del teatro en la provincia de Ávila (hasta 1900)». Cuadernos Abulenses 21, 133-168.

- (1998). Teatro y actividades afines en la ciudad de Ávila (Siglos $X V I I, X V I I I$ y XIX). Ávila: Diputación Provincial / Institución Gran Duque de Alba; con prólogo de José Romera Castillo. [Tesis de doctorado, Teatro y actividades afines en Ávila (siglos XVII, XVIII y XIX), defendida en 1993, dirigida por J. Romera Castillo y publicada en microforma en Madrid: UNED, 1994.]

GUTIÉRREZ RoBLEDO, J. L. (1987). «Imágenes de la arquitectura abulense desaparecida en la documentación del siglo XIX». En Los archivos y la investigación. Ciclo de conferencias en homenaje a Carmen Pedrosa, VV. AA., 13-32. Ávila: Archivo Histórico Provincial.

HeRnÁNDEZ de la TORRe y GarCía, J. M. ${ }^{a}$ (1972). Ávila y el teatro. Ávila: Diputación Provincial.

MAYORAL FERNÁNDEZ, J. (1927). Los viejos cosos de Ávila. Escenarios históricos y novelescos. Ávila: Tipografía de Senén Martín.

VICENTE, A. (1985). «Ávila de curas, fiestas y carnavales». Revista de Folklore LIX, 147-152.

\section{Burgos}

Alberdi Elola, L. (1980). Historia del Teatro Principal de Burgos. Burgos: Ayuntamiento.

ARChAGa MARTÍNEZ, C. A. (1997). Actividades dramáticas en el Teatro Principal de Burgos: 1858-1946. Burgos: Ayuntamiento. [Un voluminoso extracto de la tesis de doctorado, presentada en Madrid: Universidad Complutense, 1981.]

Miguel GAllo, I.J. de (1995a). Teatro y parateatro en las fiestas religiosas y civiles de Burgos (1550-1752). Burgos: Ayuntamiento. 
- (1995b). El teatro en Burgos (1550-1752). El patio de comedias. Las compañías y la actividad escénica. Estudio y documentos. Burgos: Ayuntamiento.

\section{León}

Alonso PongA, J. L. (1987). «Anotaciones "socioculturales" a la Pastorada leonesa». En Actas de las Jornadas sobre Teatro Popular en España, J. Álvarez Barrientos y A. Cea (eds.), 9-16. Madrid: CSIC.

FERNÁNDEZ GARCÍA, E. (1997). León y su actividad escénica en la segunda mitad del siglo XIX. Madrid: UNED. [Tesis de doctorado, defendida en 1997, publicada en microforma: Madrid: UNED, 1998, dirigida por J. Romera Castillo.]

MARTínez García, F. (1982). Historia de la literatura leonesa. León: Everest.

TRAPERo, M. (1982). La pastorada leonesa. Una pervivencia del teatro medieval. Madrid: Sociedad Española de Musicología.

\section{Salamanca}

CeA Gutí́rez, A. (1987). «Del rito al teatro: restos de representaciones litúrgicas en la provincia de Salamanca». En Jornadas sobre el teatro popular en España, J. Álvarez Barrientos y A. Cea Gutiérrez (eds.), 25-51. Madrid: CSIC.

ZAMORA VICENTE, A. (1954-55). «Representaciones teatrales en Salamanca de 1832-1834». Boletín de Filología (Chile) 8, 475-480.

\section{Segovia}

GRAU, M. (1958a). «El teatro en Segovia». Estudios Segovianos X, 5-98.

- (1958b). El teatro en Segovia. Segovia: Instituto Diego de Colmenares. [Ampliación del artículo anterior.] 
TANarro, Á.; Martín, A. y Aranguren, F. (1989). Crónica de un teatro. Juan Bravo 1917-1989. Segovia: Diputación Provincial. [Con referencias a estudios sobre época anterior.]

\section{Soria}

Álvarez SolAR-Quintes, M. (1963). «El teatro en Soria a mediados del siglo XIX». Celtiberia (Soria) XIV (26), 264-271.

\section{Valladolid}

Almuiña Fernández, C. (1974). Teatro y cultura en el Valladolid de la Ilustración. Los medios de difusión en la segunda mitad del siglo XVIII. Valladolid: Ayuntamiento.

Alonso Cortés, N. (1923). El teatro en Valladolid. Madrid: Tipografía de la Revista Archivos. [Publicado previamente en $B R A E$, 4-6 (1917-1923).

- (1944). Miscelánea vallisoletana. Valladolid: Imprenta del Colegio de Santiago.

- (1947). El teatro en Valladolid en el siglo XIX. Valladolid: Imprenta Castellana.

DÍEZ GARRETAS, R. (1982). El teatro en Valladolid en la primera mitad del siglo XIX. Valladolid: Institución Cultural Simancas / Diputación Provincial.

SALCEDO, E. (1978). Teatro y sociedad en el Valladolid del siglo XIX. Valladolid: Ayuntamiento.

VALLEJo GonZÁLEZ, I. (1983-84). «El teatro en Valladolid durante el siglo XVIII: Autores y obras más representados». Castilla 6-7, 143150.

VV.AA. (1986). Teatro Lope de Vega. 5 aniversarios de plata. Valladolid: Caja de Ahorros Provincial. 
Vega García-Luengos, G. (1990). «El teatro barroco en los escenarios y en las prensas de Valladolid durante el siglo XVIII». En Teatro del Siglo de Oro. Homenaje a Alberto Navarro González, V. García de la Concha et alii (eds.), 639-673. Kassel: Reichenberger.

\section{Zamora}

Ventura Crespo, C. (1988). Historia del teatro en Zamora. Zamora: Fundación Ramos de Castro.

- (1991). «El Corral de Comedias de Zamora: el edificio, origen y evolución. 1606-1990». En Teatros y vida teatral en el Siglo de Oro a través de las fuentes documentales, L. García Lorenzo y J. E. Varey (eds.), 79-97. Londres: Tamesis Books.

\section{X.9. Cataluña}

\section{Barcelona}

ALIER, R. (1983). «Wagner y el Liceo». Monsalvat 107, 17 y ss.

- (1986). El Gran Teatro del Liceo. Madrid: Ediciones Daimón.

Alier AlXaca, R. y MATA, F. X. (1991). El Gran Teatro del Liceo. Barcelona: Mata.

AMADES, J. (1933). «Titel.les i ombres chineses». Biblioteca de Tradicions Populars VIII.

ARTís, A. (1912). «El Pi, titel.laire dels Quatre Gats». Teatre Català I (Barcelona), p. 26.

ARTIS, J. (1946a). El Gran Teatro del Liceo. En Barcelona histórica y monumental, vol. VIII.

- (1946b). Primer centenario de la Sociedad del Gran Teatro del Liceo, 1847-1947. Barcelona: Montaner y Simón. [Otra edición: Barcelona: Quintilla y Cardona, 1950.] 
AviÑoA, X. (1987). «La danza en el Gran Teatro del Liceo. Vida coreográfica ochocentista». En Historia de la danza en Cataluña, P. Llorens (ed.), 72-105. Barcelona: Caja de Barcelona.

Bensoussan, A. (1982). José Yxart (1852-1895). Théâtre et critique à Barcelone. Lille: Université de Lille III, 2 vols.

BERNAT Y DURÁN, J. (1924). «Los teatros regionales catalán y valenciano». En Historia del teatro español, N. Díaz de Escovar y F. Lasso de la Vega, II, 323-428. Barcelona: Montaner y Simón.

Bertrán, M. J. (1931). El Gran Teatro del Liceo de Barcelona, 18371903. Barcelona: Oliva de Vilanova.

Bohigas Tarragó, P. (1946). Compañías dramáticas extranjeras en Barcelona. Barcelona: Instituto del Teatro.

Bravo, I. (1986). L'escenografia catalana. Barcelona: Diputación de Barcelona.

BUSQUETS, L. (1987). «Companyes teatrals italianes en la Barcelona modernista». Revista de Cataluña 14, 93-111.

CaPMANY, A. (1921). «De marionetes i titel.les». La Revista. Quaderns de Publicació Quinzenal 7, 146-147.

- (1947). Un siglo de baile en Barcelona. Barcelona: Ediciones Librería Milla.

Cayameres, F. e Iglesies, J. (1971). La dansarina Roseta Mauri (1850-1923). Reus: Asociación de Estudios Reusenses.

CIERVo, J. (1944). Federico Soler ( Pitarra»), gran figura barcelonesa. Barcelona: Librería Dalmau.

CuRET, F. (s. a.). El arte dramático en el resurgir de Cataluña. Barcelona: Minerva.

- (1967). Historia del teatre català. Barcelona: Aedos.

Dalmau, A. R. (1947). El circo en la vida barcelonesa. Barcelona: Millà.

FÁBREgAS, X. (1969). Teatre català d'agitaciò politica. Barcelona: Edicions 62.

- (1971). Ángel Guimerà: les dimensions d'un mite. Barcelona: Edicions 62. 
- (1972). Aproximaciò a la historia del teatre català modern. Barcelona: Curial.

- (1978). Historia del teatre català. Barcelona: Millà.

FONT, M. (1928). El teatre català anterior a Pitarra. Barcelona: Barcino.

FuENTES, E. de (1899). «En Titel.la». Quatre Gats 3, 2.

GrAU GUTIÉRREZ, A. M. ${ }^{a}$ (1992). El teatro en Barcelona en la segunda mitad del siglo XIX (1858-1864). Madrid: UNED. [Memoria de Investigación, inédita, dirigida por J. Romera Castillo.]

JANÉs NADAL, A. (1976). «El drama musical de Wagner visto por Joan Maragall y el doctor José de Letamendi». Anuario de Filología II, 587-594.

- (1983). La obra de Richard Wagner a Barcelona. Barcelona: Universitat de Barcelona / Fundació Vives i Casajona.

LAMAÑA, L. (1927). Barcelona filarmónica. Barcelona: Librería Camí.

LARRAZ, E. (1979). «Joseph Robrenyo et le premier théâtre catalan politique». En Hommage des hispanistes a Noël Salomon, VV. AA., 475-486. Barcelona: Laia.

Litvak, L. (1968). «Naturalismo y teatro social en Cataluña». Comparative Literature Studies (Urbana) 5, 279-302.

MARFANY, L. (1983). «El wagnerisme a Catalunya». Serra d'Or 281, 76 y ss.

Mestres Calvet, J. (1946). El Gran Teatro del Liceo visto por su empresario. Barcelona: Vergara.

MiRACle, J. (1958). Gimerà. Barcelona: Aedos.

Molins, A. E. de (1972). Diccionario biográfico y bibliográfico de escritores y artistas catalanes del siglo XIX. Hildesheim: G. Olms (Reedición, varios vols.) [1. ${ }^{\mathrm{a}}$ ed., Barcelona: Imprenta F. Giró.]

PAR, A. (1936). Representaciones shakesperianas en España. Madrid y Barcelona: Suárez y Balmes.

PoBlet, J. M. (1980). Josep Robrenyo, comediant, escriptor, revolucionari. Barcelona: Edicions 62.

PORRAS, F. (1981). Titelles. Teatro popular. Madrid: Editora Nacional. 
SAlVAT, R. (1980). La il.luminació de gas i l'espectacle del XIX a Catalunya. Barcelona: Catalana de Gas y Electricidad.

SiguÁN BoeHMER, M. (1985). «L'ideari d'Adrià Gual en el marc de la renovació del teatre català i la introducció de G. Hauptmann a Catalunya». En Homenatge a Antoni Comas, VV. AA., 435-446. Barcelona: Universidad de Barcelona.

SUBIRÁ, J. (1946). La ópera en los teatros de Barcelona. Estudio histórico-cronológico desde el siglo XVIII al XX. Barcelona: Millà, 2 vols. [Hay una edición reducida en Madrid: Alba, 1978.]

SUERO RocA, M. ${ }^{\text {a }}$ T. (1987). El teatre representat a Barcelona de 1800 a 1838. Barcelona: Institut del Teatre, 2 vols.

VAREY, J. E. (1960). «Los títeres en Cataluña en el siglo XIX». Estudios Escénicos V, 47-78.

VV.AA. (1979). «El teatre al tombant de segle (1874-1909)». L'Avenç $22,17-40$.

- (1983). Wagner i Catalunya (Antología de textos i gràfics sobre la influència wagneriana a la nostra cultura). Barcelona: Edicions del Cotal.

- (1987). Teatres de Catalunya. Barcelona: Generalitat, 2 vols.

YXART, J. (1889). El año pasado. Letras y artes en Barcelona. Barcelona: Librería Española.

- (1894-1896). El arte escénico en España. Barcelona: La Vanguardia, 2 vols. [Reedición en Barcelona: Alta Fulla, 1987.] [Nota: En Tarragona, en noviembre de 1995, se celebró un Col.loqui sobre Josep Yxart i el seu temps, que será editado por el Institut d'Estudis Tarraconenses.]

\section{Figueres}

VV.AA. (1991). Història del teatre a Figueres. Olot: Alzamora.

\section{Girona}

GARCía VidAl, P. (1990). Pastorets a Girona (Crónica de una tradició escènica). Gerona: Ayuntamiento. 


\section{Igualada}

VILA FARRÉ, M. ${ }^{\text {a }}$ R. (1992). El teatro en Igualada en la segunda mitad del siglo XIX (1863-1880). Madrid: UNED. [Memoria de Investigación, inédita, dirigida por J. Romera Castillo.]

\section{Lleida}

RABASA I FontSERRE, J. y RABASA I ReINAT, F. (1985). Historia del teatre a Lleida. Lleida: Institut d'Estudis Ilerdençs.

\section{Palafrugell}

Molinas Falgueras, L. (1987). El teatre a Palafrugell. Parafrugell: Ayuntament.

\section{Tarragona}

BaIXAUli MoRAles, E. (1969). Tarragona musical: un siglo de vida artística (1850-1950). Tarragona.

\section{X.10. Comunidad de Madrid}

\section{Alcalá de Henares}

Coso MARín, M. Á.; Higuera SÁnChez-PARdo, M. y SANZ-BALlesteROS, J. (1989). El Teatro Cervantes de Alcalá de Henares: $1602-$ 1866. Estudio y documentos. Londres: Tamesis Books. 


\section{Madrid}

Adams, N. B. (1926). «Notes on Spanish Plays at the Beginnin of te Romantic Period». Romanic Review XVII, 128-142.

- (1936). «Siglo de Oro Plays in Madrid: 1820-1050». Hispanic Review 4, 342-357.

- (1945). «Notes on Dramatic Criticism in Madrid: 1828-1933». En Studies in Language and Literature, 231-238. Chapel Hill: University of North Carolina Press. [Studies in Philology XLII, 1945, 609-616.]

- (1950). «French Influence on the Madrid Theatre in 1837». En Estudios dedicados a Menéndez Pidal, VV. AA., VII, 135-151. Madrid: CSIC.

Agulló Y COBo, M. (1983). «100 documentos sobre teatro madrileño (1582-1824)». En El teatro en Madrid (1583-1925), VV. AA., 83-137. Madrid: Ayuntamiento de Madrid-Delegación de Cultura.

Alas, L. (1887). «Temporada teatral». Nueva campaña (185-1886), 273-278.

Allen, J. T. (1983). The Reconstruction of a Spanish Golden Age Playhouse. El Corral del Príncipe, 1583-1744. Gainesville: University of Florida Press.

Alonso Seoane, M. ${ }^{a}$ J. (1995). «Nuevos datos sobre Abén Humeya y su estreno». Investigación Franco-Española (Córdoba) 12, 97109.

ANDIOC, R. (1976). Teatro y sociedad en el Madrid del siglo XVIII. Madrid: Fundación Juan March / Cátedra. [2. ${ }^{a}$ ed., 1987. 1. ${ }^{a}$ ed. francesa, 1970.]

- (1982). «Sobre el estreno de Don Álvaro». En Homenaje a Juan López Morillas, VV. AA., 63-86. Madrid: Castalia.

ANDIOC, R. y Coulon, M. (1997). Cartelera teatral madrileña del siglo XVIII (1708-1808). Toulouse: Presses Universitaires du Mirail, 2 vols.

ANDURA VARELA, F. (1992). «Del Madrid teatral del XIX: la llegada de la luz, el teatro por horas, los incendios, los teatros de verano». En Cuatro siglos de teatro en Madrid, Andrés Peláez (ed.), 85-115. 
Madrid: Consorcio para la Organización de Madrid Capital Europea de la Cultura.

ARDERfus, F. (1869). Teatro del Circo. Los Bufos de Arderíus, Tercera campaña (1868 a 1869). Madrid: s.e.

ARIAS DE Cossío, A. M. ${ }^{a}$ (1991). Dos siglos de escenografía en Madrid. Madrid: Mondadori (Prólogo de Jesús Hernández Perera).

ASENJO BARBIERI, F. (1877). El Teatro Real y el Teatro de la Zarzuela. Madrid: José M. Ducazcal. [Edición facsímil en Madrid: Música Mundana, 1985.]

Ávila Arellano, J. y MenÉndez OnRubia, C. (1988). «Teatro Espanol. Siete meses de lucha por el arte. Homenaje a los clásicos. En torno a un texto desconocido de Galdós». Revista de Literatura 99, 171-204.

Balsalobre Garcfa, J. M. ${ }^{\text {a }}$ (1997). La imagen académica del teatro español decimonónico: el teatro y su censura en la Real Academia de Bellas Artes de San Fernando (1800-1870). Madrid: UNED. [Tesis de doctorado.]

Barrera Maraver, A. (1983). Crónicas del género chico y de un Madrid divertido. Madrid: El Avapiés.

Bayón M. y Martín Gómez, J. L. (1988). El Real Coliseo de Carlos III. San Lorenzo del Escorial. Madrid: Consejería de Cultura.

BELORGEY, J. (1988). «Le théâtre espagnol d'inspiration française représenté à Madrid de 1801 à 1808». Crisol 9, 15-34.

BERENGUER, Á. (1988). Los estrenos teatrales de Galdós en la crítica de su tiempo. Madrid: Consejería de Cultura de la Comunidad de Madrid.

Bernáldez Montalvo, J. M. ${ }^{\mathrm{a}}$ (1983). Las tarascas de Madrid. Madrid: Ayuntamiento.

- (1987). «La Tarasca en el Corpus madrileño». En Jornadas sobre el teatro popular en España, J. Álvarez Barrientos y A. Cea Gutiérrez (eds.), 17-24. Madrid: CSIC.

BORRÁs, T. (1973). Madrid. Leyendas y tradiciones. Madrid: Vasallo de Mumbert.

BORREL, F. (1912). El wagnerismo en Madrid. Madrid: Valentín de Asín / José M. Ducazcal. 
Calvo Revilla, L. (1920). Actores célebres del teatro Príncipe o Español. Siglo XIX. Manera de representar de cada actor, anécdotas y datos biográficos. Madrid: Imprenta Municipal.

CAmpo, J. de (1935). Del Corral del Príncipe al Teatro Español. Madrid.

Canals, S. (1896). El año teatral 1895-1896. Crónicas y documentos. Madrid: Tipografía El Nacional. [Con un artículo preliminar sobre el público de Jacinto Octavio Picón.]

CÁRMENA Y Millán, L. (1878). Crónica de la ópera italiana en Madrid desde el año 1738 hasta nuestros días. Madrid: Manuel Minuesa de los Ríos. [Prólogo del maestro Francisco Asenjo Barbieri, que trata desde los orígenes hasta 1738.]

CARrIiere, M.-T. (1980). «Acerca de las pensiones de actores en la Cruz y el Príncipe a mediados del siglo XIX». En Homenaje a Jean-Louis Flecniakoska, I, 119-141. Montpellier: Université Paul Valéry.

CASTro, J. de (1865). Comentario joco-serio al pliego de condiciones para la subasta del Teatro Real. Madrid: Antonio Pérez Dubrull.

Chaulié, D. (1886). Cosas de Madrid. Madrid: Correspondencia de España, 2 vols.

CHICOTE, E. (s. a. [¿1943?]). La Loreto y este humilde servidor (Recuerdos de la vida de dos comediantes madrileños). Madrid: Aguilar (Prólogo de Carlos Arniches y epílogo de Fernando José de Larra).

Сobos CASTRo, E. (1981). Medio siglo de teatro francés en Madrid (1870-1920). Córdoba: Edición de la autora.

CoE, A. M. (1935). Catálogo bibliográfico y crítico de las comedias anunciadas en los periódicos de Madrid desde 1661 hasta 1819. Baltimore: The Johns Hopkins University Press.

- (1947). Entertainments in the little Theatre of Madrid, 17591819. New York: Hispanic Institute in the United States.

- (1952). Carteleras madrileñas (1677-1792, 1819). México.

COTARELO Y MORI, E. (1928). «Editores y galerías de obras dramáticas en Madrid en el siglo XIX». Revista Biblioteca, Archivo y Museo del Ayuntamiento (Madrid) 18, 121-139. 
Deleito y Piñuela, J. (s. a.). Estampas del Madrid teatral fin de siglo. I. Español. Comedia. Princesa. Novedades. Lara. Madrid: Saturnino Calleja.

DENGLER Gassin, R. (1986a). «El melodrama francés: su proceso de penetración en España, su proyección y acogida en las tablas madrileñas». Récifs 6, 138-160.

- (1986b). «El teatro francés en Madrid (1830-1850)». Resúmenes de Tesis de Doctorado, 1-24. Salamanca: Universidad.

- (1987). «El teatro de Victor Hugo a través de la prensa madrileña, 1835-1850». Studia Zamorensia 8, 222-233.

- (1989). «El drama romántico francés en Madrid (1830-1850)». En Imágenes de Francia en las letras hispánicas, F. Lafarga (ed.), 307-315. Barcelona: PPU.

- (1991). «Alcance de las traducciones de obras francesas en los repertorios teatrales madrileños entre 1830 y $1850 »$. En Estudios humanísticos en homenaje a Luis Cortés Vázquez, Roberto Dengler (ed.), 161-169. Salamanca: Universidad.

Desfretieres, B. (1962). Jean-Marie de Grimaldi et l'Espagne. París.

DOMÉNECH RICO, F., ed. (1998). La zarzuela chica madrileña. Madrid: Castalia / Comunidad de Madrid.

DuFFEY, Frank M. (1942). «Juan de Grimaldi and the Madrid Stage (1823-1837)». Hispanic Review X, 147-156.

Espín TEMPlado, M. ${ }^{\mathrm{a}}$ P. (1988). El teatro por horas en Madrid (1870-1910) (Subgéneros que comprende, autores principales y análisis de algunas obras representativas). Madrid: Universidad Complutense, 2 vols. [Tesis de doctorado. Ahora reformulada en El teatro por horas en Madrid (1870-1910), Madrid: Instituto de Estudios Madrileños / Fundación Jacinto e Inocencio Guerrero, 1995.]

FERNÁNDEZ MuÑoz, Á. L. (1989). Arquitectura teatral en Madrid. Del corral de comedias al cinematógrafo. Madrid: El Avapiés (Prólogo de Pedro Navascués Palacio).

Flores GARCí, F. (s.a.). Memorias intimas del teatro. Madrid: Sempere.

Fradejas LeBrero, J. (1992). Geografia literaria de la provincia de Madrid. Madrid: CSIC / Instituto de Estudios Madrileños (2. ${ }^{a}$ ed.). 
García MARTín, L. (1960). Manual de teatros y espectáculos públicos. Madrid: Impr. de Cristóbal González, 2. ${ }^{\mathrm{a}}$ ed.

GARRIDO GARCÍA, R. (1986). Teatro Real: historia, crónica y curiosidades. Madrid: Edición del Autor.

GIES, D. T. (1978). «Juan de Grimaldi y el año teatral madrileño 18231824». En Actas del VIII Congreso de la Asociación Internacional de Hispanistas, 607-613. Madrid: Istmo.

- (1985). «Larra, Grimaldi and the Actors of Madrid». En Studies in the Spanish Eighteenth Century Spanish Literature and Romanticism in Honor of John Dowling, D. y L. J. Barnette (eds.), 113-122. Newark: Juan de la Cuesta.

- (1986). Introducción a Juan de Grimaldi, La pata de la cabra. Roma: Bulzoni.

- (1988). Theatre and Politics in Nineteenth-Century Spain: Juan de Grimaldi as Impresario and Government Agent. Cambridge: Cambridge University Press.

- (1990). «Notas sobre Grimaldi y el "furor de refundir" en Madrid (1820-1833)». Cuadernos de Teatro Clásico 5, 111124.

- (1992). «Grimaldi, Vega y el Teatro español (1849)». En Actas del X Congreso de la Asociación Internacional de Hispanistas, A. Vilanova (ed.), II, 1.277-1.283. Barcelona: PPU.

GIEs, D. T., ed. (1986). Juan de Grimaldi, «La pata de la cabra». Roma: Bulzoni.

GIL, B. y GonzÁlez, A. (1820). Manifiesto que dan los autores en representación de los individuos de los teatros de la Cruz y del Príncipe al respetable público de esta heroica villa. Madrid: Repullés.

GÓMEZ LABAD, J. M. (1983). El Madrid de la zarzuela: visión regocijada de un paseo de cantables. Madrid: Juan Piñeiro.

GómeZ REA, J. (1977). «Las revistas teatrales madrileñas: 17901930». Cuadernos Bibliográficos XXXI, 65-140.

GonZÁlez ARACo, M. (1897). El Teatro Real por dentro, memorias de un empresario. Madrid: Imprenta de los Hijos de José Ducazcal. [2. ${ }^{\mathrm{a}}$ ed. en 1892 y reimpresiones en 1907, 1930 y 1949.]. 
GonZÁlez MAESTRE, F. (1992). Teatro Real: historia viva (18781901). Madrid: Mundimúsica.

GRASES RIERA, J. (1904). Memoria sobre las reformas más necesarias en los teatros de Madrid para poder garantizar la seguridad de los espectadores. Madrid.

GUEREÑA, J.-L. (1980). «Associations culturelles pour ouvriers et artisans à Madrid (1847-1872)». En Culture et societé en Espagne et en Amérique Latine au XIXe siècle, C. Dumas (ed.), 77-91. Lille: Université de Lille III.

Guijarro de Molina, I. y Martínez Sanz, I. (1869). Madrid en día de fiesta. Costumbres contemporáneas. Madrid: J. Peña.

GuILlÉN, E. (1880). «Estadística teatral, 1879». La Raza Latina (Madrid) VII (146), 14-16.

HARTZENBUSCH, J. E. (1847). «Lista de obras dramáticas que se han estrenado en los teatros de Madrid en el año civil de 1846». Revista Literaria de El Español I (2. época), 11-14.

HERAS, D. de las (1898). Madrid en la escena. Madrid: Casa Editorial de M. Núñez Samper (Prefacio de J. Benavente, págs. 5-8).

HerRero Garcta, M. (1963). Madrid en el teatro. Madrid: CSIC / Instituto de Estudios Madrileños.

Herrero SAlgado, F. (1963). Cartelera teatral madrileña. II: Años 1840-1849. Madrid: CSIC (Cuadernos Bibliográficos, IX).

HuERTAS VÁzQUez, E. (1989). Teatro musical español en el Madrid ilustrado. Madrid: El Avapiés.

- (1993). El teatro de los bufos madrileños. Madrid: Ayuntamiento.

Johnson, C. B. (1985). «Madrid's Third "Public" Theatre». En Studies in Eighteenth-Century Spanish Literature and Romanticism in Honor of John Cjarkson Dowling, D. y L.J. Barnette (eds.), 99-11. Newark, Delaware: Juan de la Cuesta.

JUAN MoRANT, V. (1992). «Aproximación a la arquitectura de los teatros madrileños de los siglos XVIII y XIX». En Cuatro siglos de teatro en Madrid, Andrés Peláez (ed.), 53-67. Madrid: Consorcio para la Organización de Madrid Capital Europea de la Cultura. 
UNA BIBLIOGRAFÍA (SELECTA) PARA LA RECONSTRUCCIÓN DE LA VIDA ESCÉNICA...

KANY, C. E. (1929). «Plan de reforma de los teatros de Madrid aprobado en 1799». Revista de Bibliotecas, Archivos y Museos VI, 245-284.

LAVAUD, J.-M. (1977). «Ibsen et le théâtre d'idées à Madrid à la fin du XIXe». En Théatre et societé, VV. AA., 61-74. Pau: Université.

- (1987-88). «Polémique autour d'un hypothétique "théâtre libre". Madrid. 1868». En Mélanges offerts à Maurice Molho, 143-154. París: Éds. Hispaniques.

LOPEZ, F. (1992). «El teatro madrileño durante el reinado de José Bonaparte». En Cuatro siglos de teatro en Madrid, Andrés Peláez (ed.), 69-83. Madrid: Consorcio para la Organización de Madrid Capital Europea de la Cultura.

LORENZ, Ch. M. (1938). «Seventeenth Century Plays in Madrid from 1808-1818». Hispanic Review 6, 324-331.

- (1941). «Translated Plays in Madrid Theaters (1808-1818)». Hispanic Review IX, 376-382.

MARTIN, G. C. (1985). «Querer y no poder, o el teatro español de 1825 a 1836». En Studies in Eighteenth Century Spanish Literature and Romanticism in Honor John C. Dowling, D. y L. J. Barnette (eds.), 123-131. Newark: Juan de la Cuesta.

- (1988). «Los teatros madrileños bajo Grimaldi y Gaviria». Boletín de la Biblioteca Menéndez Pelayo LXIV, 209-222.

MARTín de Sagarmínaga, J. (1997). Diccionario de cantantes líricos españoles. Madrid: Acento / Fundación Caja de Madrid.

Martínez Olmedilla, A. (1947). Los Teatros de Madrid (Anecdotario de la farándula madrileña). Madrid: Ed. José Ruiz Alonso.

MARTORI, J. (1995). La projecció d'Angel Guimerà a Madrid (18911924). Barcelona: Curial / Publicacions de l'Abadia de Montserrat.

MemBrez, N. J. (1987). The «Teatro por horas»: History, Dynamics and Comprehensive Bibliography of a Madrid Industry. 1867-1922 (género chico, género ínfimo and early cinema). Santa Bárbara: Diss. University of California, 3 vols.

— (1989-90). «The "género ínfimo" in Madrid (1898-1922)». Siglo XX / XXe Century VII, 1-6. 
- (1992). «The Bureaucratization of the Madrid Theater: Government Censorships, Curfews and Taxation (1868-1925)». Anales de la Literatura Española Contemporánea 17, 99-123.

MenÉNDEZ OnRubIA, C. (1987). «Representaciones dramáticas entre 1887 y 1893» [en Madrid]. En su obra, Neorromanticismo español y su época. Epistolario de José Echegaray a María Guerrero, 93135. Madrid: CSIC.

Mesonero Romanos, R. de (1844). Manual histórico-tipográfico administrativo y artístico de Madrid. Madrid: Yanes.

- (1861). El antiguo Madrid. Madrid: Mellado.

- (1983). Escenas matritenses. Madrid: Méndez Editores (Reproducción facsímil de las ediciones de 1845 y 1851). [Otra edición en Madrid: Ábaco, 1983.]

MONTANER, J. (1954). El estreno de «La muerte de César» de Ventura de la Vega (1866). Madrid: Real Escuela Superior de Arte Dramático.

Mora Martín, J. (1960). Historia breve del teatro Fontalba. Madrid.

Moreno Carbayo, N. (1957). Catálogo de los documentos referentes a diversiones públicas. Madrid: Archivo Histórico Nacional.

Muñoz, M. (1946). Historia del Teatro Real. Madrid: Tesoro.

- (1965-1970). Historia del teatro dramático en España: II. La ópera y el Teatro Real; y III. La zarzuela y el género chico. Madrid: Tesoro, 3 vols.

PAR, A. (1936). Representaciones shakespearianas en España. Madrid / Barcelona: Victoriano Suárez / Balmes.

Peláez, A., ed. (1992). Cuatro siglos de teatro en Madrid. Madrid: Consorcio para la Organización de Madrid Capital Europea de la Cultura.

PICOCHE, J.-L. (1970). «Los amantes de Teruel». Introduction, édition critique et synoptique precedée d'une étude sur le monde du théâtre à Madrid entre 1833 et 1850. París: Centre des Recherches Hispaniques, 2 vols. [Trad..$^{\circ}$ castellana abreviada, Madrid: Alhambra, 1980.]

PRIETo, A. (inédito). Teoría del arte cómico y elementos de oratoria y declamación para la enseñanza de los alumnos del Real Conserva- 
UNA BIBLIOGRAFIA (SELECTA) PARA LA RECONSTRUCCIÓN DE LA VIDA ESCÉNICA...

torio de María Cristina. Ms. 2.804 de la Biblioteca Nacional de Madrid.

ReVILla, J. de la (1945). Vida artística de Isidoro Máiquez, primer actor de los teatros de Madrid. Madrid: Medina y Navarro.

RomeA, J. (1858). Ideas generales sobre el Arte del Teatro, para uso de los alumnos de clase de declamación del Real Conservatorio de Madrid. Madrid: Abienzo.

ROMERo TOBAR, L. (1972). «Noticias sobre empresas teatrales en periódicos del siglo XIX». Segismundo 15-16, 235-279.

- (1988). «La Colección General de Comedias, de Ortega (Madrid, 1826-1834)». En Homenaje a Simón Díaz, VV. AA., 599-609. Kassel: Reichenberger.

RuIz AlbÉnIz, V., Chispero (¿1953?). Teatro Apolo. Historial, anecdotario y estampas madrileñas de su tiempo (1873-1929). Madrid: Prensa Castellana.

RUMEAU, A. (1939). «Le théâtre à Madrid à la veille du Romanticisme (1831-1834)». En Hommage à Ernest Martinenche. Études Hispaniques et Américaines, 330-346. París: Éd. D’Artrey.

Sárnz De Robles, F. C. (1952). Los antiguos teatros de Madrid. Madrid: Instituto de Estudios Madrileños.

- (1981). El teatro en el Madrid del siglo XIX. Madrid.

San Martín, A. (1870). Confidencias de Arderíus. Historia de un bufo, referida por... Madrid: Imprenta Española.

SÁNCHEZ CARRERA, M. ${ }^{a}$ C. (1989). «El Teatro Real en el reinado de Alfonso XII: la temporada 1879-1880». En La sociedad madrileña durante la Restauración, VV. AA, 241-250. Madrid: Comunidad de Madrid / Revista Alfoz.

SÁNCHEZ SALAS, B. (1998). «Representando a Bretón». En Bretón de los Herreros: 200 años de escenarios, M.Á. Muro (ed.), 145-161. Logroño: Instituto de Estudios Riojanos.

SCHINASI, M. (1988). «The Nacional Theater in Mid-Nineteenh Century Spain, and the Curious Project to Destroy a Block of Houses Facing the Teatro Español». En Resonancias románticas. Evocaciones del Romanticismo español, VV. AA., 195-205. Madrid: Porrúa. 
Seminario de Bibliografía Hispánica de la Facultad de Filosofía Y LETRAS DE MADRID (1961). Cartelera teatral madrileña. I: 1830 1839. Madrid: CSIC (Cuadernos Bibliográficos, III). [Cf. además F. Herrero Salgado (1963).]

- (1961-69). Madrid en sus diarios (1830-1900). Madrid: Instituto de Estudios Madrileños, 5 vols.

SepúlvedA, E. (1887). La vida en Madrid en 1886. Madrid: Fernando Fe.

- (1888). La vida en Madrid en 1887. Madrid: Ricardo Fe.

SePúlveda, R. (1888). El Corral de la Pacheca (Apuntes para la historia del teatro español). Madrid: Librería de Fernando Fe. [Edición facsímil: Madrid: Asociación Libreros de Lance de Madrid, 1993.]

SePúlveda y Planter, E. (1887). La vida en Madrid en 1886. Madrid: Fernando Fe. [Otra edición en Madrid: Asociación Libreros de Lance de Madrid, 1994.]

SHIELDS, A. K. (1933). The Madrid Stage 1820-1830. Chapel Hill: University of North Carolina (Tesis de doctorado inédita).

Simón Díaz, J. (1963). «Los clásicos españoles en la prensa diaria de Madrid». Revista de Literatura XXIII, 209-240.

- (1964). «Los clásicos españoles en la prensa diaria de Madrid». Revista de Literatura XXIV, 201-237.

- (1967). «Las ferias de Madrid en la literatura». Anales del Instituto de Estudios Madrileños, t. II, 249-274.

- (1981). Madrid en su prensa del siglo XIX. Madrid: Instituto de Estudios Madrileños.

Simón Palmer, M. ${ }^{a}$ C. (1974). «Construcción y apertura de teatros madrileños en el siglo XIX». Segismundo X, 85-124. [Tirada aparte en Madrid: Instituto de Estudios Madrileños, 1975.]

- (1983). «Planos y noticias de algunos teatros madrileños del siglo XIX». En El teatro en Madrid (1583-1925). Del Corral del Príncipe al Teatro de Arte, VV. AA., 53-71. Madrid: Ayuntamiento.

- (1987). «Diversiones populares madrileñas en el siglo XIX». En Actas de las Jornadas sobre teatro popular en España, J. Álvarez Barrientos y A. Cea Gutiérrez (eds.), 185-192. Madrid: CSIC. 
- (1989). El gas y los madrileños (1832-1936). Madrid: Gas Madrid / Espasa Calpe.

SoPEÑa IbÁÑ̃z, F. (1967). Historia crítica del Conservatorio de Madrid. Madrid: Ministerio de Educación.

SUBIRÁ, J. (1945). Historia de la música teatral española. Barcelona: Labor. [Sintetiza el libro de José Bilbao, Teatro Real. Recuerdos de cinco temporadas del empresario Arana, que comprende el periodo que va desde 1850 a 1900.]

- (1949). Historia y anecdotario del Teatro Real. Madrid: Plus Ultra. [Edición facsímil de Luis Suñén, Madrid: Acento / Fundación Caja de Madrid, 1997.]

- (1950). El teatro del Real Palacio (1849-1851). Con un bosquejo preliminar sobre la música palatina desde Felipe $V$ hasta Isabel II. Madrid: CSIC.

- (1960). El gremio de representantes españoles y La Cofradía de Nuestra Señora de la Novena. Madrid: Instituto de Estudios Madrileños.

- (1971). Temas musicales madrileños (Evocaciones históricas). Madrid: Instituto de Estudios Madrileños.

Thomason, Ph. B. (1987). The Coliseo de la Cruz: Madrid's firts Enclosed Municipal Playhouse (1735-1859). Universidad de Kentucky (Tesis de doctorado inédita).

Turina Gómez, J. (1997). Historia del Teatro Real. Madrid: Alianza.

VAREY, J. E. (1955-1957). «Robertson's Phantasmagoria in Madrid 1821». Theatre Notebook IX, 89-95; y XI, 82-91.

- (1959). Títeres, marionetas y otras diversiones populares de 1758 a 1859. Madrid: Instituto de Estudios Madrileños.

- (1972). Los títeres y otras diversiones populares de Madrid: 1758-1840. Estudio y documentos. Londres: Tamesis Books.

- (1996). Cartelera de los títeres y otras diversiones populares de Madrid: 1758-1840. Estudio y documentos. Madrid: Támesis.

VV.AA. (1968-75). Veinticuatro diarios de Madrid 1830-1900. Articulos y noticias de escritores españoles del siglo XIX. Madrid: CSIC, 4 vols. 
- (1975). Madrid en sus diarios. Madrid: CSIC, 5 vols.

- (1983). El teatro en Madrid (1583-1925). Del Corral del Príncipe al Teatro de Arte. Madrid: Ayuntamiento-Delegación de Cultura.

\section{X.11. Comunidad Valenciana}

\section{General}

López-Chavarri ANDújar, E. y Doménech Prat, J. (1978). Cien años de música valenciana. 1878-1978. Valencia: Caja de Ahorros.

VV.AA. (1992). Espais Teatrals a la Comunitat Valenciana. Valencia: Generalitat.

\section{Alicante}

LLORET I ESQUERDO, J. (1998). El teatre a Alacant 1833-1936. Valencia: Consell Valencià de Cultura / Generalitat Valenciana.

MARTINEZ, M. (1984). «El sainet a la ciutat d'Alacant». Canelobre 1, 45-52.

Ramos PËrez, V. (1965). El Teatro Principal en la historia de Alicante (1847-1947). Alicante: Ayuntamiento.

- (1966). Literatura alicantina (1839-1939). Madrid: Alfaguara.

Rfos Carratalá, J. A. (1987). Románticos y provincianos (La literatura en Alicante, 1839-86). Alicante: Universidad / Caja de Ahorros Provincial de Alicante.

SANCHIS GuARNER, M. (1980). Els inicis del teatre valencià modern (1845-1874). Valencia: Facultad de Filología. 


\section{Castellón}

JULIÁ MARTÍNEZ, E. (1930). Representaciones teatrales de carácter popular en la provincia de Castellón. Madrid: Tipografía de Archivos.

\section{Valencia}

BERNAT Y DURÁN, J. (1924). «Los teatros regionales catalán y valenciano». En Historia del teatro español, N. Díaz de Escovar y F. P. Lasso de la Vega, II, 323-428. Barcelona: Montaner y Simón.

Centelles, C. (1993). Teatro en la prensa valenciana: 1844-1850. Valencia: Universidad (Tesis de doctorado).

Cubedo Capella, J. (1982). Teatres de la Diputació de València. Valencia: Diputación.

Guastavino Gallent, G. y Guastavino Robba, S. (1974). «Un siglo de teatro valenciano (Materiales para su estudio)». Revista de Archivos Bibliotecas y Museos LXXVII, 149-325.

IZQuIERDo IZQuIERDo, L. (1982). La vida teatral en Valencia (18001850). Pamplona: Universidad de Navarra. [Tesis de doctorado inédita, publicada en parte en BRAE LXIX (1989) y en la Revista de la Institución Alfonso el Magnánimo (Valencia).]

- (1985). «Los bailes en las representaciones dramáticas de Valencia (1800-1850)». En Homenatge a José Esteve Forriol, VV. AA., 103-109. València: Departament de Filologia Clàssica.

- (1986). «Comedias de magia en Valencia (1800-1850)». Revista de Literatura 96, 387-405.

- (1989). «El teatro en Valencia (1800-1832)». Boletín de la Real Academia Española 69, 257-305.

- (1990). «El teatro menor en Valencia (1800-1850) (Comedias en un acto, piezas en un acto y sainetes)». Revista de Literatura 103, 101-127. 
LAMARCA, L. (1840). El teatro en Valencia desde su origen hasta nuestros días. Valencia.

SANCHIS GUARNER, M. (1980). Els inicis del teatre valencià modern (1845-1874). Valencia: Facultad de Filología.

SIRERA, J. Ll. (1984). «El Principal de València i les representacions en valencià durant el segle XIX». Estudis Escènics (Barcelona) $24,77-94$.

- (1986). El Teatre Principal de València. Aproximació a la seva història. Valencia: IVEI / Institució Alfons el Magnànim.

SIRERA, J. Ll. y MiRAlleS, R. (1997). «Representar el sainete valenciano: imágenes textuales y tradición interpretativa». En Del oficio al mito: el actor en sus documentos, Evangelina Rodríguez (ed.), II, 363-408. Valencia: Acadèmia dels Nocturns, Universitat.

ZABALA, A. (1960). La ópera en la vida teatral valenciana del siglo XVIII. Valencia: Institución Alfonso el Magnánimo.

- (1982). El teatro en la Valencia de finales del siglo XVIII. Valencia: Institución Alfonso el Magnánimo.

\section{Vinaroz}

GÓMEz ACEBES, A. (1996). Historia del teatro en Vinarós: de los orígenes a la guerra civil española. Vinarós (Castellón): Antinea.

\section{X.12. Extremadura}

\section{Badajoz}

SANABRIA, J. (1980). "Teatros de Badajoz». Revista Alminar XIX.

SuÁrez Muñoz, Á. (1995). La vida escénica en Badajoz 1860-1886. Madrid: UNED (en microforma). [Tesis de doctorado, defendida en 1994, dirigida por J. Romera Castillo. Publicada porteriormente como El teatro en Badajoz: 1860-1886. Cartelera y estudio (Ma- 
UNA BIBLIOGRAFÍA (SELECTA) PARA LA RECONSTRUCCIÓN DE LA VIDA ESCÉNICA...

drid: Támesis, 1997, Colección «Fuentes para la historia del teatro en España», $n .^{\circ}$ XXVIII).]

Vera Camacho, J. P. y Lebrato Fuentes, F. (1980). «Extremadura: escena y actor». Revista de Estudios Extremeños XXXVI (1), 143192.

VV.AA. (1985). Rehabilitación del Teatro López de Ayala. Badajoz I Madrid: Estudio Dos / Arquitectos.

\section{Cáceres}

VILlaCAMPa, C. G. (1921). «Las representaciones escénicas en Guadalupe». Boletín de la Real Academia Española VIII, 453-456.

\section{X.13. Galicia}

\section{General}

SÁNCHEZ GARCÍA, J. Á. (1995). «Los primeros teatros a la italiana de Galicia. Arquitectura y vida escénica (1804-1832)». En El siglo XIX... Y la burguesía también se divierte, Ana S. Pérez-Bustamante Mourier et alii (eds.), 344-369. El Puerto de Santa María: Fundación Pedro Muñoz Seca / Ayuntamiento.

- (1997). La arquitectura teatral gallega. La Coruña: Fundación Pedro Barrie de la Maza. [Tesis de doctorado: La arquitectura teatral gallega. Estudio histórico de una tipología. Santiago de Compostela: Universidad, 1995.]

SoRAluce Blond, J. R. (1988). «El espacio del espectáculo: los primeros teatros de Galicia». Boletín Académico de la ETSA de La Coruña 9, 26-37. [Además de otros trabajos sobre «El espacio del espectáculo en Galicia: del teatro al salón de variedades», aparecidos en los números 11,12 y 13 de la citada revista.] 


\section{A Coruña}

Díaz PARDEIRO, J. R. (1992). La vida cultural en La Coruña: el teatro (1882-1915). La Coruña: Ayuntamiento / Galicia Editorial.

Vigo Trasancos, A. (1991). «La arquitectura teatral en La Coruña del siglo XVIII (1766-1804)». Revista del Instituto José Cornide 26, 125-151.

\section{Ferrol}

Alonso Torreiro, J. L.; Gainzos Corbeira, A. y Rodríguez DiAz, A. (1986). Los teatros en Ferrol. El teatro Jofré. El Ferrol: Concello de Ferrol / Colegio de Arquitectos de Galicia.

Castelo Álvarez, B. (1995). Pasado y presente del Teatro Jofre. Ferrol: Cuadernos Ferrol-Análisis.

Fonticoba Graña, A. (1981). «El teatro Jofre de Ferrol». Boletín Académico (La Coruña: Escuela Técnica Superior de Arquitectura) 13.

OCAMPO YIGO, M. ${ }^{a}$ E. (1997). La vida escénica en el teatro Jofre de Ferrol (1892-1896). Madrid: UNED. [Memoria de Investigación inédita, dirigida por José Romera Castillo.]

\section{Pontevedra}

APARICIO MORENO, P. (1996). La vida escénica en Pontevedra: 19011903. Madrid: UNED. [Memoria de Investigación inédita, dirigida por Pilar Espín Templado.]

Ruibal Outes, T. (1997). La vida escénica en Pontevedra en la segunda mitad del siglo XIX. Madrid: UNED (en microforma). [Tesis de doctorado defendida en 1997, dirigida por J. Romera Castillo.] 


\section{Santiago de Compostela}

SÁNCHEZ GARCÍA, J. Á. (1993). La arquitectura teatral en Santiago de Compostela, 1768-1946. Sada (La Coruña): Ediciós do Castro.

\section{X.14. La Rioja}

BENITO ARGálz, I. (1997). El teatro en Logroño (1889-1893). Logroño: Universidad de La Rioja. [Memoria de Investigación, inédita, dirigida por M. ${ }^{a}$ Pilar Espín Templado y Miguel Ángel Muro.]

BENITO MARTIN, F. et alii (1994). «Sociedad, cultura y ocio». En Historia de la ciudad de Logroño, J. A. Sesma Muñoz (ed.), t. IV, Edad Moderna (II), Edad Contemporánea (I), 465-469. Zaragoza: Ibercaja / Ayuntamiento de Logroño.

Bravo Vega, J. y Domínguez MatrTo, F. (1999). «El Liceo de Logrono (1868): localización de un nuevo espacio teatral». Signa (UNED, Madrid) 8, 181-200.

CÁseda TEResA, J. (1987). «1841: Un teatro romántico en Calahorra». Berceo 112-113, 23-32.

DOMÍNGUEZ MATrTo, F. (1994). «El teatro en Logroño». En Historia de la ciudad de Logroño, J. A. Sesma Muñoz (ed.), t. IV, Edad Moderna (II), Edad Contemporánea (I), 75-85. Zaragoza: Ibercaja / Ayuntamiento de Logroño.

- (1998). El teatro en La Rioja: 1580-1808. Los patios de comedias de Logroño y Calahorra. Estudio y documentos. Logroño: Servicio de Publicaciones de la Universidad de La Rioja.

GoICOECHEA, C. J. (1947). «Un anuncio teatral» [1870]. Berceo 3, 303.304.

GONZÁlez LATRE, M P. et alii (1999). «Espectáculos y diversiones». En el prólogo a la edición facsímil de El Diluvio. Semanario Festivo Ilustrado (1897-1898), 83-93. Logroño: Gobierno de la Rioja / Instituto de Estudios Riojanos / Ayuntamiento. 
JiMÉnez MARTíneZ, J. (1990). 1879-1979. El teatro Bretón de los Herreros en su primer centenario. Logroño: Ochoa.

Martínez San Celedonio, M. (1978). Historia de Calahorra. Calahorra: Gutenberg.

Sáenz Cenzano, S. (1951). «Apuntes históricos de Logroño. El teatro». Berceo 21, 581-598.

SOMAlo Fernández, M. ${ }^{a}$ Á. (1988). El teatro en Calahorra (18401910). Madrid: UNED. [Memoria de Licenciatura, inédita, dirigida por José Romera Castillo.]

\section{X.15. Murcia}

ARroniz, M. R. (1858). El carnaval de Murcia de 1854. Murcia.

BarCeló Jiménez, J. (1980). Historia del teatro en Murcia. Murcia: CSIC / Academia Alfonso X el Sabio, 2. ${ }^{\mathrm{a}} \mathrm{ed}$.

Cerdán Casado, A. (1986). Historiografía del teatro en Águilas. Águilas: Ayuntamiento.

Crespo, A. (1993). Historia del Teatro de los Infantes, de Murcia. Murcia: Real Academia Alfonso X El Sabio.

Díez de Revenga, F. J. y PACo, M. de (1989). Historia de la literatura murciana, 290-311. Murcia: Universidad / Academia Alfonso X El Sabio / Editora Regional.

Oliva, C. (1999). Breve historia del Teatro Romea de Murcia. Murcia: Ayuntamiento / Concejalía de Cultura y Festejos.

VV.AA. (1968). Julián Romea, primer centenario (1868-1968). Murcia: Ayuntamiento.

\section{X.16. Navarra}

Corella Iraizoz, J. M. (1971). Teatro en Pamplona. Pamplona: Diputación Foral. 
FERNÁNDEZ DE LARRINJA, K. (1997). Mujer, ritual y fiesta. Género, antropología y teatro de carnaval en el valle de Soule. Pamplona: Lamia.

OnRUBia Pascual, F. (1995). «Pervivencia de la comedia decimonónica en la cartelera pamplonesa del primer cuarto del siglo XX». En El siglo XIX... Y también la burguesía se divierte, Ana S. PérezBustamante Mourier et alii (eds.), 309-314. El Puerto de Santa María: Fundación Pedro Muñoz Seca / Ayuntamiento.

\section{X.17. País Vasco}

\section{Bilbao}

Alonso Bocos, M. ${ }^{\text {a }}$ B. (1996). El teatro en Bilbao (1890-1892). Madrid: UNED. [Memoria de Investigación, dirigida por J. Romera Castillo.]

Bacigaluce, C. (1988). Bilbao a escena. Bilbao: Ayuntamiento.

BAlsalobre GARCía, J. M. ${ }^{a}$ (1998). «La arquitectura teatral a través de las pruebas de pensado en la Real Academia de Bellas Artes de San Fernando». Espacio, Tiempo y Forma (Madrid, UNED), Serie VII, H. ${ }^{\mathrm{a}}$ del Arte, 11, 261-286. [Cf. epígrafe 1.2.1, «Proyecto de teatro ideado en 1826 para la ciudad de Bilbao», 268-272.]

Basas, M.; Bacigalupe, C. y CHAO, Á. (1995). Vida y milagros del teatro Arriaga (1890-1990). Bilbao: Ayuntamiento, 2. ${ }^{\mathrm{a}}$ ed. aumentada (Edición de Alfonso Carlos Sáiz-Valdivieso).

EnRique Uralde, R. (1982). Teatro en Bilbao. Bilbao: Caja de Ahorros Vizcaína.

Garamendi Azcorra, M.A. (1991). El teatro popular vasco. Semiótica de la representación. San Sebastián: Diputación Foral de Guipúzcoa.

Hérelle, G. (1923). «Études sur le théâtre basque. Les tragicomédies de Carnaval». Revue International des Études Basques 14, 541-557. 


\section{X.18. Otros}

\section{Tetuán (Marruecos)}

BACAICOA, D. (1953). «El teatro en Tetuán en el año 1860». Revista de Literatura III, 5-6, 79-98.

\section{HISTORIA Y CULTURA}

Abellán, J. L. (1984). Historia del pensamiento español. IV: Liberalismo y Romanticismo (1808-1868). Madrid: Espasa Calpe.

- (1989). Historia crítica del pensamiento español. La crisis contemporánea (1875-1936). Madrid: Espasa Calpe, 2 vols.

Álvarez LÁzaro, P. F. (1985). Masonería y Libre Pensamiento en la España de la Restauración. Madrid: Universidad de Comillas.

ARANGUREN, J. L. L. (1966). Moral y sociedad. Introducción a la moral social española del siglo XIX. Madrid: Edicusa.

ARTOLA, M., ed. (1991). La burguesía revolucionaria (1808-1874). Madrid: Alianza. [Vol. 5 de la Historia de España.]

Bahamonde, Á. y MARTínez, J.A. (1994). Historia de España. Siglo $X I X$. Madrid: Cátedra.

BotREL, J.F. et alii (1997). «Coordenadas y cauces de la vida literaria». En Historia de la literatura española. Siglo XIX (I), V. García de la Concha (ed.) y G. Carnero (coord.), t. 8, 1-73. Madrid: Espasa Calpe.

Brigss, A. (1989). El siglo XIX. Las contradicciones del progreso. Madrid: Alianza.

CAMBronero, C. (1914). Crónicas del tiempo de Isabel II. Madrid: La España Moderna.

CARNERo, G. (1997). «Introducción a la primera mitad del siglo XIX español». En Historia de la literatura española. Siglo XIX (I), V. García de la Concha (ed.) y G. Carnero (coord.), t. 8, XVII-C. Madrid: Espasa Calpe. 
CARR, R. (1968). España 1808-1939. Barcelona: Ariel.

Charnon-Deutsch, L. (1985). The Nineteenth-century Spanish Story. Textual Strategies of a Genre in Transition. Londres: Tamesis Books.

Cirujano Marín, P. et alii (1985). Historiografia y nacionalismo español, 1834-1868. Madrid: Centro de Estudios Históricos.

Comellas, J. L. (1977). La Restauración como experiencia histórica. Sevilla: Universidad.

CuEnCA TORIBIo, J. M. (1979). Iglesia y burguesía en la España liberal. Madrid.

- (1980). Sociedad y clero en la España del siglo XIX. Córdoba.

Díaz-PlaJA, G. (1963). La vida española en el siglo XIX. Madrid: Aguado.

DíEZ DEL CORRAL, L. (1973). El liberalismo doctrinario. Madrid: Centro de Estudios Constitucionales.

Duby, G. y Perrot, M. (1993). Historia de las mujeres. El siglo XIX. Madrid: Taurus, vol. 4. [Vid. especialmente para España los trabajos de Marina Mayoral, «Las amistades románticas: un mundo equívoco» y M. ${ }^{a}$ Carmen Simón Palmer, «Mujeres rebeldes».]

Dumas, C., ed. (1980). Culture et societé en Espagne et en Amérique Latine au XIXe siècle. Lille: Université de LIlle III.

- (1985). L'homme et l'espace dans la littérature, les arts et l'histoire en Espagne et en Amérique Latine au XIXe siècle. Lille: Université de Lille III.

ESPADAS, M. y URQUIJO, J. R. de (1990). La guerra de la independencia y la época constitucional (1808-1898). Madrid: Gredos. [Tomo 11 de la Historia de España.]

FERNÁNDEZ, A. (1976). Historia contemporánea. Barcelona: Vicens Vives.

FERNÁNDeZ Almagro, M. (1974). Historia política de la España contemporánea. Madrid: Alianza, 3 vols., 3. ${ }^{\mathrm{a}} \mathrm{ed}$.

Flores, A. (1968). La sociedad de 1850. Madrid: Alianza. [Prólogo de Jorge Campos.]

Gómez Molleda, M. a D. (1966). Los reformadores de la España contemporánea. Madrid: CSIC. 
JOVER ZAMORA, J. M. ${ }^{\mathrm{a}}$ (1981). Revolución burguesa, oligarquía y constitucionalismo (1834-1923). Barcelona: Labor. [Tomo VIII de la Historia de España, dirigida por Manuel Tuñón de Lara.]

JOVER ZAMORA, J. M. ${ }^{\text {a }}$, ed. (1981). La era isabelina y el sexenio democrático (1814-1874). Madrid: Espasa-Calpe. [Tomo XXXIV de la Historia de España, fundada por Ramón Menéndez Pidal.]

JUTGLAR, A. (1971). Ideologías y clases en la España contemporánea (1874-1931). Madrid: Edicusa.

LARRA, F. J. de (1947). La sociedad española a través del siglo XIX. Madrid: Ministerio de Trabajo.

Legaz LaCAMBra, L. (1960). Estudios de historia social de España. Madrid: CSIC, 4 vols.

LIDA, C. E. y ZAVAL, I. M., eds. (1970). La Revolución de 1868. Historia, Pensamiento, Literatura. Nueva York: Las Americas Publishing Company.

LITVAK, L. (1980). Transformación industrial y literatura en España (1895-1905). Madrid: Taurus.

- (1981). Musa libertaria. Arte, literatura y vida cultural del anarquismo español (1880-1913). Barcelona: Antoni Bosch.

LIDA, C. E. y ZaVAlA, I. M., eds. (1970). La revolución de 1868. Historia, pensamiento y literatura. Nueva York: Las Américas P. C.

Lissorgues, Y. y Sobejano, G., eds. (1988). Pensamiento y literatura en España en el siglo XIX (Idealismo, Positivismo, Espiritualismo). Toulouse: Presses Universitaires de Toulouse-Le Mirail.

LISSORGUES, Y. et alii (1998). «Del Realismo al fin de siglo. Sociedad y arte literario». En Historia de la literatura española. Siglo XIX (II), V. García de la Concha (ed.) y L. Romero Tobar (coord.), t. 9, 1-105. Madrid: Espasa Calpe.

LiTVAK, L. (1981). Musa libertaria. Arte, literatura y vida cultural del anarquismo español (1880-1913). Barcelona: Anthropos.

Llanos y Alcaraz, A. (1864). La mujer en el siglo XIX. Madrid: Librería de San Martín.

LLORENS, V. (1973). Liberales y románticos. Una emigración española a Inglaterra (1823-1834). Madrid: Castalia, 3. ${ }^{\mathrm{a}} \mathrm{ed}$. 
LÓPEz ARANGUREn, J. L. (1974). Moral y sociedad. La moral social española en el siglo XIX. Madrid: Edicusa.

MADOZ, P. (1846-1849). Diccionario geográfico-estadístico-histórico de España y sus posesiones de Ultramar. Madrid: Imprenta del Diccionario Geográfico / Establecimiento Literario-Tipográfico P. Madoz y L. Sagasti, 10 vols.

MAINER, J.-C. (1972). Literatura y pequeña burguesía en España (1890-1950). Madrid: Edicusa.

MARTínez CUADRADO, M. (1974). La burguesía conservadora (18741931). Madrid: Alianza. [Tomo VI de la Historia de España. Reedición, Restauración y crisis de la monarquía (1874-1931) (Madrid: Alianza, 1991).]

MARTÍNEZ MARTIN, J. A. (1991). Lectura y lectores en el Madrid del siglo XIX. Madrid: CSIC.

MartíneZ Olmedilla, A. (1957). Anecdotario del siglo XIX. Madrid: Aguilar.

MenÉndez PidAl, G. (1988-89). La España del siglo XIX vista por sus contemporáneos. Madrid: Centro de Estudios Constitucionales.

Molina, C. A. (1989). Prensa literaria en Galicia (1809-1920 y 19201960). Vigo: Xerais, 2 vols.

MORENO Alonso, M. (1979). Historiografía romántica española. Introducción al estudio de la Historia en el siglo XIX. Sevilla: Universidad.

NADAL, J. (1976). La población española (Siglos XVI a XX). Barcelona: Ariel.

Peiró Martín, I. (1995). Los guardianes de la Historia. La historiografía académica de la Restauración. Zaragoza: Institución Fernando el Católico.

Pérez MoredA, V. y ReHER, D.-S., eds. (1988). Demografía histórica en España. Madrid: Ediciones El Arquero.

ROMERO TOBAR, L. (1998). «Introducción a la segunda mitad del siglo XIX en España». En Historia de la literatura española. Siglo XIX (II), V. García de la Concha (ed.) y L. Romero Tobar (coord.), t. 9, XIX-LVI. Madrid: Espasa Calpe.

RuBIO JiMÉnEZ, J. (1994). «Sociabilidad urbana y cultura. El siglo XIX». En La sociedad urbana en la España contemporánea, F. 
Bonamusa y J. Serrallonga (eds.), 199-232. Barcelona: Asociación de Historia Contemporánea.

Salaün, S. y SerRano, C., eds. (1991). 1900 en España. Madrid: Espasa Calpe.

SeCo Serrano, C. (1973). Sociedad, literatura y política en la España del siglo XIX. Madrid: Guadiana.

Sobrequés Vidal, S. (1969). Historia de España Moderna y Contemporánea. Barcelona: Vicens Vives. [Con la colaboración de A. Bellsolá Rey.]

TADIÉ, J. Y. (1970). Introduction a la vie littéraire du XIX siècle. París: Bordas.

Tortella Casares, C. et alii (1981). «Revolucioón burguesa, Oligarquía y Constitucionalismo». En Historia de España, M. Tuñón de Lara (dir.). Barcelona: Labor.

Tũ̃ón DE LARA, M. (1970). Medio siglo de cultura española (18851936). Madrid: Tecnos.

- (1974). La España del siglo XIX. Barcelona: Laia.

Tuñón DE LARA, M. et alii (1975). Prensa y sociedad en España (1820-1936). Madrid: Cuadernos para el Diálogo.

TUÑón DE LARA, M., ed. (1981). Historia de España. Revolución burguesa, oligarquía y constitucionalismo (1834-1932). Barcelona: Labor.

VAlera OrTega, J. (1977). Los amigos políticos. Partidos, elecciones y caciquismo en la Restauración (1875-1900). Madrid: Alianza.

VV.AA. (1972). Historia social de España siglo XIX. Madrid: Guadiana.

- (1975). La crisis de fin de siglo: ideología y literatura. Estudios en memoria de R. Pérez de la Dehesa. Barcelona: Ariel.

- (1995). Antiguo Régimen y liberalismo. Madrid: Alianza, 3 vols. [1. Visiones generales; 2. Economía, sociedad y 3. Política y cultura (volumen éste editado por P. Fernández Albaladejo y M. Ortega, de gran interés.]

VÁzquez de Mella y FanJul, J. (1952). Regionalismo y Monarquía. Madrid: Rialp. 
Vicens Vives, J. (1961). Historia de España y de América. Barcelona: Vicens Vives, t. V.

- (1969). Historia económica de España. Barcelona: Vicens Vives.

VILlaCORTA BAÑos, F. (1980). Burguesía y cultura. Los intelectuales españoles en la sociedad liberal (1808-1931). Madrid: Siglo XXI.

Walis, S. T. (1853). Spain. Her Institutions, Politics, and Public Man. A Sketch. Boston: Reed and Fields.

\section{PRENSA 14}

Almuiña FeRnÁNDEZ, C. (1977). La prensa vallisoletana durante el siglo XIX (1808-1894). Valladolid: Institución Cultural Simancas.

ÁlVAREZ, J. T. (1981). Restauración y prensa de masas. Los engranajes de un sistema (1875-1883). Pamplona: EUNSA.

ARAúso Costa, L. (1946). Biografía de «La Época». Madrid: Libros y Revistas.

ASENJo, A. (1933a). La prensa madrileña a través de los siglos (Apuntes para una historia desde el año 1661 al de 1925). Madrid: Ayuntamiento / Artes Gráficas Municipales.

- (1933b). Catálogo de las publicaciones periódicas madrileñas existentes en la Hemeroteca Municipal de Madrid (1661-1930). Madrid: Artes Gráficas Municipales.

Asún, R. (1979). El proyecto editorial de «La España Moderna» y la literatura (1894-1914). Barcelona: Universidad de Barcelona.

BELlido, P. (1993). Literatura e ideología en la prensa socialista (1885-1917). Sevilla: Alfar.

BERNARDO ARES, J. M. de (1981). Ideologías y opciones políticas a través de la prensa a finales del siglo XIX. Córdoba: Imprenta Provincial.

14 Especifico solamente algunos estudios sobre publicaciones periodicas de importantes localidades. 
BESER, S. (1966). «Índices de colaboraciones de Leopoldo Alas en la prensa barcelonesa». Archivum 16, 157-211.

Blanco Martín, M. (1987). «Opinión pública y libertad de prensa (1808-1868)». En La prensa española durante el siglo XIX, VV. AA. 27-51. Almería: Instituto de Estudios Almerienses.

BLASCO, R. (1983). La premsa del País Valencià (1790-1983), vol. 1. Valencia. Institución Alfonso el Magnánimo.

Botrel, J. F. (1993). Libros, prensa y lectura en la España del siglo XIX. Madrid: Fundación Germán Sánchez Ruipérez.

BOTREL, J.F. et alii (1997). «Coordenadas y cauces de la vida literaria». En Historia de la literatura española. Siglo XIX (I), V. García de la Concha (ed.) y G. Carnero (coord.), t. 8, 1-73 [Cf. «El auge de la prensa periódica», 43-59]. Madrid: Espasa Calpe.

BozAL, V. (1979). La Ilustración gráfica del siglo XIX en España. Madrid: Alberto Corazón.

CÁrCel OTI, V. (1980). «Obispos, clero y católicos, prensa y legislación eclesiástica en la España del siglo XIX». Escritos del Vedat (Torrente, Valencia) X, 107-128.

CARMAÑola, C. (seud.) (1871). Los periodistas en camisa. Madrid. [Artículos de costumbres sobre la vida periodística.]

CARNERO, G. (1997). «Introducción a la primera mitad del siglo XIX español». En Historia de la literatura española. Siglo XIX (I), V. García de la Concha (ed.) y G. Carnero (coord.), t. 8, XVII-C [Cf. «El auge de la prensa periódica», LIV-LVII.]. Madrid: Espasa Calpe.

CASAdo Jorge, M. ${ }^{a}$ y Zamora LuCAS, F. (1952). Publicaciones periódicas en la Biblioteca Nacional. Madrid: Ministerio de Educación Nacional.

Castro, C. de (1975). Romanticismo, periodismo y política. Andrés Borrego. Madrid: Tecnos.

CAzottes, G. (1982). La presse périodique madrilène entre 1871 et 1885. Montpellier: Université Paul Valéry.

Celma Valero, M. ${ }^{a}$ P. (1989a). La crítica de actualidad en el fin de siglo (Estudio y textos). Salamanca: Plaza Mayor Universitaria.

- (1989b). La pluma ante el espejo (Visión autocrítica del «fin de siglo», 1888-1907). Salamanca: Universidad. 
- (1991). Literatura y periodismo en las revistas de fin de siglo. Estudio e Índices (1888-1907). Madrid: Júcar.

Cepedello Boiso, J. (1995). «Teoría del teatro en la prensa sevillana del XIX: La Revista de Ciencias, Literatura y Artes (1855-1860)». En El siglo XIX... y la burguesía también se divierte (Actas del I Congreso de Historia y crítica del teatro de comedias), A.S. Pérez Bustamante et alii (eds.), 75-80. El Puerto de Santa María, Cádiz: Fundación Pedro Muñoz Seca / Ayuntamiento.

Checa Godoy, A. (1991). Historia de la prensa andaluza. Sevilla: Fundación Blas Infante.

DÉROZIER, A. (1982). «Relaciones entre Historia y Literatura a través de la producción periodística del Trienio Constitucional». En Actas del VII Congreso de la Asociación Internacional de Hispanistas, VV. AA., IV, 383-391. Roma: Bulzoni.

Dueñas, J. y SERRANo, A. (1990). Historia del periodismo en Aragón. Zaragoza: Diputaciones de Zaragoza, Huesca y Teruel.

ENGLEKIRK, J. E. (1955). «El Museo Universal (1857-69): Mirror of Transition Years». PMLA LXX, 350-374.

EsPINA, A. (1960). El cuarto poder. Madrid: Aguilar.

Esteve Ramírez, F. (1989). «Prensa y movimientos sociales en la última etapa de la Restauración». En La sociedad madrileña durante la Restauración, VV. AA., 333-344. Madrid: Comunidad de MadridRevista Alfoz.

FonTANELla, L. (1982). La imprenta y las letras en la España romántica. Berna / Frankfurt: M. Peter Lang.

GARCÍA TORRES, J. Á. (1984). El periodismo literario en la prensa diaria madrileña (1896-1904). Madrid: Universidad Complutense.

GIL Novales, A., ed. (1983). La prensa en la revolución liberal. Madrid: Universidad Complutense.

GÓMEZ APARICIO, P. (1967-1974). Historia del periodismo español (De la Revolución de septiembre al desastre colonial). Madrid: Editora Nacional, varios vols.

GómEZ IMAZ (1910). Los periódicos durante la Guerra de la Independencia (1808-1814). Madrid: Biblioteca Nacional. 
GÓMEZ REA, J. (1978). «Las revistas teatrales madrileñas (17901930)». Cuadernos Bibliográficos 32, 65-140.

GOMEZ VillafranCA, R. (s. a.). Índices de materias y autores de "La España Moderna». Tomos 1. a 264. Enero de 1889 a diciembre de 1910, formados aplicando el sistema de clasificación bibliográfica decimal. Madrid: La España Moderna.

González-Blanco, E. (1919). Historia del periodismo. Desde sus comienzos hasta nuestra época. Madrid: Biblioteca Nueva.

GoNZÁlez RuIZ, N. (1958). «Periodismo y literatura periodística en el siglo XIX». En Historia general de las literaturas hispánicas, G. Díaz-Plaja (ed.), vol. V, 145-183. Barcelona: Vergara.

GUARNER, L., ed. (1953). «El Europeo» (Barcelona, 1823-1824). Madrid: CSIC.

GUEREÑA, J. L. (1982). «Las estadísticas oficiales de la prensa (18671927)». En Metodología de la historia de la prensa española, VV. AA., 81-119. Madrid: Siglo XXI.

GUINARD, P. J. (1973). La presse espagnole de 1737 à 1791. Formation et signification d'un genre. París: Centre de Recherches Hispaniques.

HARTZENBUSCH, E. (1894). Apuntes para un catálogo de periódicos madrileños desde el año 1661 al 1870. Madrid: Sucesores de Rivadeneyra.

HibBS-LisSORgues, S. (1991). «La prensa católica catalana de 1868 a 1900» (I)». Anales de Literatura Española de la Universidad de Alicante 7, 99-119.

- (1993). «La prensa católica catalana de 1868 a 1900 (II)». Anales de Literatura Española de la Universidad de Alicante 9, 85-101.

- (1994). «La prensa católica catalana de 1868 a 1900 (III)». Anales de Literatura Española de la Universidad de Alicante 10, 147-172.

- (1995). Iglesia, prensa y sociedad en España (1868-1904). Alicante: Instituto de Cultura Juan Gil-Albert.

Iglesias, F. (1980). Historia de una empresa periodística: Prensa Española editora de «ABC»y «Blanco y Negro» (1891-1978). Madrid: Prensa Española. 
JiMÉNEZ MORELL, I. (1992). La prensa femenina en España (desde sus orígenes a 1868). Madrid: Ediciones de la Torre.

LABANDEIRA FERNÁNDEZ, A. (1976). Índices de publicaciones periódicas. Madrid: Fundación Universitaria Española.

LE GENTL, G. (1909). Les revues littéraires de l'Espagne pendat la première moitié du XIX ${ }^{e}$ siècle. Aperçu bibliographique. París: Hachette.

LissorguES, Y. (1981). La producción periodística de Leopoldo Alas. Toulouse: Université de Toulouse-Le Mirail.

LÓPEZ Ruiz, J. M. ${ }^{\text {a }}$ (1995). La vida alegre. Historia de las revistas humorísticas, festivas y satíricas publicadas en la Villa y Corte de Madrid. Madrid: Compañía Literaria.

Magallón Antón, F. et alii (1959). Índice de «Revista de Archivos, Bibliotecas y Museos», 1871-1957, con un apéndice correspondiente a 1958. Madrid.

Molina, C. A. (1989). Prensa literaria en Galicia (1809-1920) y Prensa literaria en Galicia (1920-1960). Vigo: Ediciones Xerais, 2 vols.

Molina FAJARDo, E. (1979). Historia de los periódicos granadinos (siglos XVIII y XIX). Granada: Diputación.

OSSORIO Y BERNARD, M. (1903-1904). Ensayo de un catálogo de periodistas españoles del siglo XIX. Madrid: Imprenta J. Palacios.

Ossorio y Gallardo, C. y Á. (1891). Manual del perfecto periodista. Madrid: La España Editorial.

PÁEz Ríos, E. (1952). «El Museo Universal». Madrid (1857-1869). Madrid: CSIC.

Palenque, M. (1987). «El Cisne. Periódico semanal de Literatura y Bellas Artes. Descripción, estudio e índice de un periódico romántico sevillano». Archivo Hispalense 213, 141-177.

- (1990). Gusto poético y difusión literaria en el Realismo español. «La Ilustración Española y Americana» (1869-1905). Sevi1la: Alfar.

- (1998). «Del Realismo al fin de siglo. Sociedad y arte literario: Prensa y creación literaria durante la Restauración (18741902)». En Historia de la literatura española. Siglo XIX (II), V. García de la Concha (ed.) y L. Romero Tobar (coord.), t. 9, 5973. Madrid: Espasa Calpe. 
PAscual, P. (1989). «Católicos, ultramontanos y reaccionarios en la prensa de la Restauración». En La sociedad madrileña durante la Restauración, VV. AA., 307-318. Madrid: Comunidad de MadridRevista Alfoz.

PAz, R., ed. (1950). «Revista Contemporánea» (Madrid, 1875-1907). Madrid: CSIC.

Perinat, A. y MARRADEs, M. ${ }^{a}$ I. (1980). Mujer, prensa y sociedad en España (1800-1939). Madrid: Centro de Investigaciones Sociológicas.

Polo BENITO, J. (1901). Del periodismo católico. Plasencia: Imprenta de Manuel Ramos.

Rey Faraldos, G. (1990). «Prensa literaria en Galicia». Ínsula 527, 5.

RIBBANS, G. (1958). «Riqueza inagotable de las revistas literarias modernas». Revista de Literatura 25-26.

REPLINGER, M. (1991). El pensamiento artístico en las revistas románticas españolas (1835-1855). Madrid: Universidad Complutense.

ROBLES MuÑoz, C. (1988). «La prensa y la división de los católicos en la Restauración». Hispania Sacra XL, 431-468.

RODRÍGUEZ DE LA FLOR, J. L. (1993). Prensa satírica en España (18321932). Madrid: Ediciones de La Torre.

Roig Castellanos, M. (1986). La mujer en la historia (Francia, Italia, España). A través de la prensa. Siglos XVIII-XX. Madrid: Instituto de la Mujer.

Romero Tobar, L. (1975). «Sobre censura de periódicos en el siglo XIX. Algunos expedientes gubernativos de 1832 a 1849». En Homenaje a D. Agustín Millares Carlo, I, 465-500. Las Palmas: Caja Insular de Ahorros.

- (1987). «Prensa periódica y discurso literario en la España del siglo XIX». En La prensa española durante el siglo XIX. I Jornadas de especialistas en prensa regional y local, VV. AA., 93104. Almería: Instituto de Estudios Almerienses.

- (1990). «Relato y grabado en las revistas románticas: los inicios de una relación». Voz y Letra I.2, 157-170.

- (1994). «Publicaciones periódicas y creación literaria». En su obra, Panorama crítico del Romanticismo español. Madrid: Castalia. 
Rubio CRemades, E. (1984). «La prensa satírica madrileña en el Romanticismo». Romanticismo (Génova) 2, 168-174.

- (1995). Periodismo y literatura: Ramón Mesonero Romanos y el «Semanario Pintoresco Español». Alicante: Institut de Cultura Juan Gil-Albert.

RUBIO JIMÉNEZ, J. (1982). «Colaboraciones de Benavente en la prensa madrileña: 1890-1900». Cuadernos Bibliográficos del CSIC (Madrid) 44, 1-17.

SÁnChez Aranda, J. J. y Barrera del Barrio, C. (1988). Lecciones de historia del periodismo español. Pamplona: EUNSA.

Schulte, H. F. (1968). The Spanish Press (1470-1966). Print, Power and Politic. Chicago: University of Illinois Press.

Seminario de Bibliografía Hispánica de la Facultad de Filosofía Y LETRAS DE MADRID (1961-69). Madrid en sus diarios (18301900). Madrid: Instituto de Estudios Madrileños, 5 vols.

- (1968-1975). Veinticuatro diarios (Madrid, 1830-1900). Artículos y noticias de escritores españoles del siglo XIX. Madrid: CSIC, 4 vols.

SEOANE, M. ${ }^{a}$ C. (1977). Oratoria y periodismo en la España del siglo $X I X$. Madrid: Fundación Juan March / Castalia.

- (1983). Historia del periodismo en España. II: el siglo XIX. Madrid: Alianza.

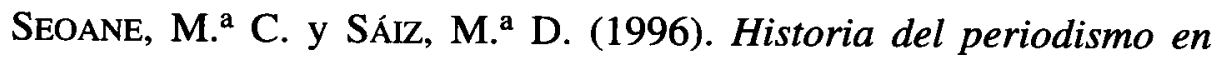
España. III: el siglo XX (1898-1936). Madrid: Alianza.

Silvela, F. (1887). «Orígenes, historia y caracteres de la prensa española». En La España del siglo XIX, III, 221-248.

Simón CABARGA, J. (1982). Historia de la prensa santanderina. Santander: Diputación.

Simón DíAZ, J. (1963). «Los clásicos españoles en la prensa diaria de Madrid, 1830-1900». Revista de Literatura 23 (45-46), 209-240 y 24 (47-48), 201-237.

- (1975). «La prensa española en la época de Zorrilla». En Estudios Románticos, 311-325. Valladolid: Casa-Museo de Zorrilla. 
- (1981). Madrid en su prensa del siglo XIX. Madrid: Instituto de Estudios Madrileños.

Simón PAlmer, M. ${ }^{a}$ del C. (1975). «Revistas españolas femeninas del siglo XIX». En Homenaje a D. Agustín Millares Carlo, VV. AA., I, 401-445. Las Palmas: Caja Insular de Ahorros de Gran Canaria.

- (1980). «Revistas destinadas a la familia en el siglo XIX». Cuadernos Bibliográficos del CSIC 40, 161-170.

- (1993). Revistas femeninas madrileñas. Madrid: Ayuntamiento.

Timoteo Álvarez, J. (1981). Restauración y prensa de masas. Los engranajes de un sistema (1875-1883). Pamplona: EUNSA.

- (1986). «Estructura subterránea de la prensa en la Restauración». En Madrid en la sociedad del siglo XIX, I, 229-248. Madrid: Consejería de Cultura de la Comunidad de Madrid.

TRENC BAllester, E., ed. (1996). La prensa ilustrada en España. Las «Ilustraciones» (1850-1920). Montpellier: Université.

Tuñón De LARA, M. et alii (1975). Prensa y sociedad en España (1820-1936). Madrid: Edicusa.

VALls, J. F. (1988). Prensa y burguesía en el XIX español. Barcelona: Anthropos.

VV.AA. (1898-99). El mundo de los periódicos. Anuario de la prensa española y estudios hispano-americanos. Libro para todos. Manual del viajero. Diario del año. Guía práctica del Reclamo. Madrid: Hernando y Cía.

- (1911). El libro de la prensa. Madrid: Renacimiento (Prólogo de Miguel Moya).

- (1972). Románticos y socialistas. Prensa española del siglo XIX. Madrid: Siglo XXI.

- (1982). Metodología de la historia de la prensa española. Madrid: Siglo XXI.

- (1987). La prensa española durante el siglo XIX. I Jornadas de especialistas en prensa regional y local. Almería: Instituto de Estudios Almerienses.

- (1993). Periodismo en Aragón. Cultura burguesa y letras provincianas. Zaragoza: Mira. 
UNA BIBLIOGRAFÍA (SELECTA) PARA LA RECONSTRUCCIÓN DE LA VIDA ESCÉNICA...

ZAVALA, I. M. (1967). «La prensa exaltada en el trienio constitucional: "El Zurriagazo"». Bulletin Hispanique LXIX, 365-388.

- (1972). «Revistas y periódicos románticos, 1835-1865». En su obra, Románticos y socialistas. Prensa española del siglo XIX, 39-125. Madrid: Siglo XXI.

ZUBATSKY, D. S. (1975 y 1984). «An International Bibliography of Cumulative Indexes to Journals Publishing Articles on Hispanic Language and Literatures». Hispania 58, 75-101; e Hispania 67, 383-393.

jromera@flog.uned.es 